\title{
Murine Norovirus: Propagation, Quantification, and Genetic Manipulation
}

Seungmin Hwang, ${ }^{1}$ Bader Alhatlani, ${ }^{2}$ Armando Arias, ${ }^{2}$ Sarah L. Caddy, ${ }^{2}$ Constantina Christodoulou, ${ }^{2}$ Juliana Bragazzi Cunha, ${ }^{3}$ Ed Emmott, ${ }^{2}$ Marta Gonzalez-Hernandez, ${ }^{3}$ Abimbola Kolawole, ${ }^{3}$ Jia Lu, ${ }^{2}$ Christine Rippinger, ${ }^{3}$ Frédéric Sorgeloos, ${ }^{2}$ Lucy Thorne, ${ }^{2}$ Surender Vashist, ${ }^{2}$ Ian Goodfellow, ${ }^{2}$ and Christiane E. Wobus ${ }^{3}$

${ }^{1}$ Department of Pathology, University of Chicago, Chicago, Illinois

${ }^{2}$ Division of Virology, Department of Pathology, University of Cambridge, Cambridge, United Kingdom

${ }^{3}$ Department of Microbiology and Immunology, University of Michigan Medical School, Ann Arbor, Michigan

\section{ABSTRACT}

Murine norovirus (MNV) is a positive-sense, plus-stranded RNA virus in the Caliciviridae family. It is the most common pathogen in biomedical research colonies. MNV is also related to the human noroviruses, which cause the majority of nonbacterial gastroenteritis worldwide. Like the human noroviruses, MNV is an enteric virus that replicates in the intestine and is transmitted by the fecal-oral route. MNV replicates in murine macrophages and dendritic cells in cells in culture and in the murine host. This virus is often used to study mechanisms in norovirus biology, because human noroviruses are refractory to growth in cell culture. MNV combines the availability of a cell culture and reverse genetics system with the ability to study infection in the native host. Herein, we describe a panel of techniques that are commonly used to study MNV biology. Curr. Protoc. Microbiol 33:15K.2.1-15K.2.61. ( 2014 by John Wiley \& Sons, Inc.

Keywords: murine norovirus $\bullet$ purification $\bullet$ quantification $\bullet$ reverse genetics $\bullet$ transfection

\section{INTRODUCTION}

Murine norovirus (MNV) is a small non-enveloped virus with a plus-sense RNA genome $\sim 7.5 \mathrm{~kb}$ in length. MNV is a member of the calicivirus family, norovirus genus, and all strains isolated to date are exclusively found in norovirus genogroup V (Green, 2007). MNV is highly abundant in research mice (e.g., Hsu et al., 2005; Kitajima et al., 2009; Mahler and Kohl, 2009). MNV-1 was originally isolated from immunocompromised mice (Karst et al., 2003), but later shown to infect wild-type mice (Mumphrey et al., 2007; Chachu et al., 2008). Many different strains of MNV have been isolated from wildtype or genetically modified mice in biomedical research colonies (e.g., Thackray et al., 2007). MNV has also been detected in wild rodents (Smith et al., 2012; Tsunesumi et al., 2012). It is the only norovirus that efficiently grows in tissue culture (in macrophages and dendritic cells) and in a small animal host (Karst et al., 2003; Wobus et al., 2004, 2006). Many biological features, including fecal-oral transmission, replication in the intestine, and fecal shedding are shared between murine and human noroviruses (Wobus et al., 2006). Therefore, MNV is often used as a model to study norovirus biology.

The following protocols describe a variety of methods typically used to analyze different aspects of MNV biology. The protocols begin with a description of how to generate viral stocks and purify MNV (Basic Protocol 1 and Alternate Protocol 1). This is followed by a method to measure anti-MNV antibodies in sera of mice to verify whether mice in

Current Protocols in Microbiology 15K.2.1-15K.2.61, May 2014

Published online May 2014 in Wiley Online Library (wileyonlinelibrary.com).

DOI: $10.1002 / 9780471729259 . m c 15 k 02 s 33$

Copyright $\odot 2014$ John Wiley \& Sons, Inc.
Animal RNA Viruses 
biomedical research colonies are seronegative prior to their use in experiments (Basic Protocol 2). Next, three different protocols to generate MNV mutants are described (Basic Protocol 3, Alternate Protocol 2, Basic Protocol 4), followed by measuring viral titers either by detection of infectious particles or genome (Basic Protocol 5, Alternate Protocol 3, and Alternate Protocol 4). Basic Protocol 6 describes strand-specific quantification of MNV-1 RNA. The unit ends with protocols describing several methods to modulate a host gene of interest in a variety of cell lines or primary cells to study its effect on MNV infection (Basic Protocols 7 to 9 and Alternate Protocol 5).

CAUTION: MNV is a Biosafety Level 2 (BSL-2) pathogen in some countries (e.g., U.S.A.). Follow all appropriate guidelines and regulations for the use and handling of pathogenic microorganisms.

NOTE: All solutions and equipment coming into contact with living cells must be sterile, and aseptic techniques should be used accordingly.

NOTE: All culture incubations should be performed in a humidified $37^{\circ} \mathrm{C}, 5 \%$ to $10 \%$ $\mathrm{CO}_{2}$ incubator unless otherwise specified.

BASIC PROTOCOL 1

Murine Norovirus: Propagation, Quantification, and Genetic Manipulation

15K.2.2

\section{GENERATION OF MURINE NOROVIRUS-CONTAINING CELL LYSATE}

This procedure outlines the making of a MNV-containing cell lysate (hereafter referred to as MNV stock). We describe the generation of an MNV-1 stock by infecting RAW 264.7 cells. However, this protocol can be used with other MNV strains and other cell lines that support viral replication and yield high viral titer, such as SRDC or BV-2 cell lines (Blasi et al., 1990; Ruiz et al., 2005). The MNV stock is useful for a wide range of applications, such as virus concentration and purification (see Support Protocols 1 and 2). Depending on the MNV strain, viral titers of $10^{6}$ to $10^{7} \mathrm{pfu} / \mathrm{ml}$ are routinely obtained after 2 days of infection.

\section{Materials}

RAW 264.7 cells (ATCC no. TIB-71)

Complete DMEM-10 medium (see recipe)

MNV-1 (available via materials transfer agreement from Dr. Herbert Virgin, virgin@wustl.edu; or other murine norovirus strains of interest)

$175-\mathrm{cm}^{2}$ tissue culture-treated flasks

Cell scraper (e.g., Sarstedt-39 cm)

Sterile, disposable plastic tubes for storing the lysate and aliquots

Additional reagents and equipment for determining viral titer by TCID $_{50}($ Basic Protocol 5) or plaque assay (Alternate Protocol 3)

\section{Culturing of RAW 264.7 cells for MNV-1 expansion}

1. Scrape RAW 264.7 cells from a confluent $175-\mathrm{cm}^{2}$ flask.

2. Resuspend RAW 264.7 cells in fresh complete DMEM-10 medium and make a single-cell suspension.

3. Seed cells at a density of $4 \times 10^{7}$ cells per $175-\mathrm{cm}^{2}$ flask in $30 \mathrm{ml}$ of complete DMEM-10.

This is roughly a 1:3 dilution of a confluent flask. Be sure to resuspend the RAW 264.7 cell well to obtain a single-cell suspension.

\section{RAW 264.7 cells infection}

4. Infect cells with MNV-1 at MOI $=0.05$ by pipetting virus directly into the medium using a pipettor. Carefully mix virus with medium after flask has been closed.

5. Incubate in tissue culture incubator at $37^{\circ} \mathrm{C}$ with $5 \% \mathrm{CO}_{2}$ for 40 to $48 \mathrm{hr}$. 
6. Check cells for the presence of cytopathic effect (CPE).

CPE can be easily observed, since the cell monolayer will be detaching from the flask. If most cells are still attached, incubate for a few more hours.

7. Dislodge any remaining attached cells by hitting the side of the flask.

8. Pool contents from all flasks and transfer cell lysate containing virus into a sterile container.

9. Freeze lysate at $-80^{\circ} \mathrm{C}$, then thaw. Repeat.

10. Aliquot lysate and store at $-80^{\circ} \mathrm{C}$.

Frozen lysate is stable for months to years at $-80^{\circ} \mathrm{C}$. However, avoid repeated freeze/thaw of virus stocks (i.e., more than five times).

11. Determine viral titers by $\mathrm{TCID}_{50}$ (Basic Protocol 5) or plaque assay (Alternate Protocol 3).

It is best to titer MNV-1 regular stock at least three times independently before calculating the final virus titer of the stock.

\section{GENERATION OF A CONCENTRATED MURINE NOROVIRUS STOCK}

This protocol describes the process of generating a concentrated MNV stock from MNVcontaining cell lysate (see Basic Protocol 1). The concentrated MNV stock is used for techniques that require higher virus titers typically obtained by growing MNV in RAW 264.7 cells (i.e., $10^{6}$ to $10^{7} \mathrm{pfu} / \mathrm{ml}$ ). The MNV concentrated stock is particularly important for animal challenge experiments, due to the small size of the host and the intrinsic limitations on the volume that can be administered to mice by the different infection routes. Typically, one can expect a $2 \log$ increase over the MNV lysate. So if the MNV stock titer is $10^{7} \mathrm{pfu} / \mathrm{ml}$, one can expect an MNV concentrated stock titer around $10^{9} \mathrm{pfu} / \mathrm{ml}$.

\section{Materials}

MNV stock (see Basic Protocol 1)

$30 \%(\mathrm{w} / \mathrm{v})$ sucrose solution in tissue-culture PBS, filter sterilized with $0.22-\mu \mathrm{m}$ filter (e.g., Millipore Stericup Express Plus system)

Phosphate-buffered saline (PBS), pH 7.4, sterile (e.g., Life Technologies, cat. no.10010-023)

Refrigerated tabletop tissue culture centrifuge (e.g., Sorvall Legend RT)

$36 \mathrm{ml}$ clear ultra-centrifuge tubes (e.g., Beckman-Coulter, cat. no. 344058)

Ultracentrifuge (e.g., Sorvall WX Ultra 80) with rotor and buckets for the appropriate volume (e.g., Sorvall AH-629)

Additional reagents and equipment for determining viral titer by $\mathrm{TCID}_{50}$ (Basic Protocol 5) or plaque assay (Alternate Protocol 3)

1. Thaw MNV stock and break apart cell debris by vigorously vortexing the viruscontaining lysate.

2. Pellet large cell debris by centrifugation in tabletop tissue culture centrifuge for $20 \mathrm{~min}$ at $2000 \times g, 4^{\circ} \mathrm{C}$.

3. Pool supernatants.

4. Add $5 \mathrm{ml}$ each of the sterile-filtered $30 \%$ sucrose solution to the bottom of six Ultraclear centrifuge tubes.

Animal RNA Viruses 
5. Very carefully overlay lysate $(\sim 30 \mathrm{ml})$ onto sucrose cushion.

It is imperative to add lysate very slowly onto the sucrose cushion to minimally disturb it.

The ultracentrifuge tubes should be full in order to minimize protocol duration and prevent cracking of the tubes (leave around $0.5 \mathrm{~cm}$ free to prevent spilling).

6. Balance all tubes and load into ultracentrifuge rotor.

7. Centrifuge in $\mathrm{AH}-629$ rotor $3 \mathrm{hr}$ at $95,000 \times g, 4^{\circ} \mathrm{C}$.

8. Discard supernatant.

9. Repeat steps 4 to 8 until all lysate has been pelleted.

We use the same tubes twice in order to minimize the volume and thus increase virus titer per volume.

10. Add $200 \mu 1$ of tissue-culture PBS per tube to resuspend pellet.

11. Seal tubes (e.g., Parafilm) and incubate overnight at $4{ }^{\circ} \mathrm{C}$.

The incubation period is necessary to allow pellet to loosen and to be easily resuspended.

12. Pool the contents of all tubes.

13. Rinse each of the six ultra-centrifuge tubes with $500 \mu l$ of tissue-culture PBS and combine with the previously pooled concentrated MNV stock (from step 12).

14. Aliquot concentrated MNV stock into 2-ml screw cap tubes and store at $-80^{\circ} \mathrm{C}$.

15. Determine viral titer by $\mathrm{TCID}_{50}$ or plaque assay (see Basic Protocol 5 or Alternate Protocol 3).

SUPPORT PROTOCOL 2

Murine Norovirus: Propagation, Quantification, and Genetic Manipulation

15K.2.4

\section{PURIFICATION OF MNV BY CESIUM CHLORIDE DENSITY GRADIENT CENTRIFUGATION}

This protocol describes the purification of MNV particles from cellular debris based on differential density of virions and cellular proteins/protein complexes. Several different protocols have been published for cesium chloride purification of caliciviruses (e.g., Madore et al., 1986; Parwani et al., 1990). They mainly differ in the way the virus is released from cells, the method for concentration of virus particles prior to purification, and the number of density gradients performed. The protocol described below is a very basic one that includes relatively few steps. It is designed for the purification of approximately $180 \mathrm{ml}$ of MNV stock (see Basic Protocol 1). For purification of MNV from larger volumes, see Alternate Protocol 1. Keep virus-containing solutions cold whenever possible.

\section{Materials}

MNV stock (see Basic Protocol 1)

$30 \%$ (w/v) sucrose solution PBS, filter sterilized with $0.22-\mu \mathrm{m}$ filter (e.g., Millipore Stericup Express Plus system)

Phosphate-buffered saline (PBS), pH 7.4, sterile (e.g., Life Technologies, cat. no.10010-023)

Cesium chloride $(\mathrm{CsCl})$

95\% ethanol

Refrigerated ultracentrifuge and Beckman rotors SW32 and SW55

Ultraclear centrifuge tubes for SW32 (Beckman Coulter, cat. no. 344058) and SW55 rotors (Beckman Coulter, cat. no. 344057) 
Refractometer

22-G needles

$10 \mathrm{kDa}$ MWCO dialysis tubing

Dialysis clips

Additional reagents and equipment for dialysis (Zumstein, 1998) and SDS-PAGE including gel staining (APPENDIX 3M)

1. Freeze/thaw flasks containing MNV-containing cell lysate.

This protocol is for $\sim 180 \mathrm{ml}$ lysate from six $175-\mathrm{cm}^{2}$ flasks, with $30 \mathrm{ml}$ medium in each flask.

2. Break apart cell debris by vortexing flasks containing cell lysate. Pool all lysates.

3. Centrifuge lysate $20 \mathrm{~min}$ at $2000 \times g, 4^{\circ} \mathrm{C}$, in a tabletop tissue-culture centrifuge to pellet large cellular debris. Save supernatant.

4. Place $5 \mathrm{ml}$ of $30 \%$ sucrose solution in bottom of a SW32 Beckman Ultraclear centrifuge tube. Very slowly layer $30 \mathrm{ml}$ supernatant on top of $30 \%$ sucrose cushion and place in SW32 rotor.

Do not mix the solutions. The clear sucrose solution and the phenol-red containing lysate should be clearly separated.

5. Repeat step 4 for the other five centrifuge tubes. Make sure that all tubes are balanced before starting the ultracentrifuge; use remaining cell lysate or PBS to balance tubes.

Prepare a total of six tubes, one for each bucket of the SW32 rotor.

6. Centrifuge $3.0 \mathrm{hr}$ at $130,000 \times g, 4^{\circ} \mathrm{C}$.

Make sure all tubes are balanced and have the same weight before starting the ultracentrifuge.

7. Discard the supernatant. Place tube upside down on paper towel to drain remaining solution.

A slightly yellowish/brownish pellet should be visible at the bottom of each tube.

8. Suspend the viral pellets from three tubes in $1 \mathrm{ml}$ PBS. Rinse all tubes with $0.5 \mathrm{ml}$ PBS. Pool all supernatants into a final volume of $2.5 \mathrm{ml}$.

Make sure pellets are completely resuspended. You may have to incubate the pellet with $P B S$ for several hours at room temperature or at $4{ }^{\circ} \mathrm{C}$ overnight. If chunks remain, vortex the pooled supernatant vigorously and pipet up and down to completely dissolve pellets.

This will increase yields. In addition, rinse tubes with PBS to prevent excess loss of virus.

9. Suspend $1.9 \mathrm{~g} \mathrm{CsCl}$ in $2 \mathrm{ml}$ PBS.

10. Mix dissolved pellet with $\mathrm{CsCl}$ solution. Check the refractive index (RFI) using a refractometer and adjust to 1.365 to 1.367 , if necessary, by adding $\mathrm{CsCl}$ salt to increase the density of the solution. Add solution to SW55 centrifuge tube.

Make sure to prepare a balance tube of identical weight for the ultracentrifuge.

11. Centrifuge overnight ( 18 to $24 \mathrm{hr}$ ) at $148,000 \times g, 4^{\circ} \mathrm{C}$, in SW55 Ti rotor to prepare the gradient.

12. Wipe bottom of tube with $95 \%$ ethanol, drill a hole in the bottom of the tube with a 22-G needle, and collect 0.5 - to 1-ml fractions.

13. Determine refractive index of each fraction using a refractometer.

Animal RNA

Viruses 
ALTERNATE PROTOCOL 1
14. Dialyze fractions (Zumstein, 1998) with refractive index of 1.362 to 1.373 against two changes of 2-liters PBS, using an MWCO $10 \mathrm{kDa}$ dialysis membrane overnight at $4^{\circ} \mathrm{C}$.

15. Analyze gradient fractions by running $5 \mu$ from each fraction on an SDS-PAGE gel and Coomassie staining (all procedures described in APPENDIX 3M) to check the purity.

The capsid protein should be visible $\sim 58 \mathrm{kDa}$.

\section{PURIFICATION OF MNV BY CESIUM CHLORIDE DENSITY GRADIENT CENTRIFUGATION (LARGE-SCALE)}

This protocol is designed for use with 1 liter of MNV stock (see Basic Protocol 1 on how to generate the virus stock). This protocol can be adjusted to accommodate even larger volumes of virus lysate. It also includes a solvent-extraction step to separate virus from cellular debris. Keep virus-containing solutions cold whenever possible.

\section{Materials}

MNV stock (Basic Protocol 1)

$\mathrm{NaCl}$

PEG 8000

Phosphate-buffered saline (PBS), pH 7.4, sterile (e.g., Life Technologies, cat. no. 10010-023)

Vertrel XF (non-hazardous freon substitute; DuPont)

$\mathrm{CsCl}$ gradient solutions with densities of 1.35 and $1.45 \mathrm{~g} / \mathrm{cm}^{3}$

95\% ethanol

Mid-speed centrifuge with SLA-3000 rotor and buckets

Stir plate in cold room with beaker and stir bar

Sonicator with sonicator tip (e.g., Fisher Scientific, Sonic Dismembrator model 550)

Beckman Coulter Ultracentrifuge with SW32 rotor and tubes

22-G needles

Refractometer

$10 \mathrm{kDa}$ MWCO dialysis tubing

Dialysis clips

Additional reagents and equipment for dialysis (Zumstein, 1998) and SDS-PAGE including gel staining (APPENDIX $3 M$ )

\section{Virus concentration with PEG 8000}

1. Thaw 1 liter of MNV stock (see Basic Protocol 1).

2. Freeze-thaw MNV stock two times.

3. Clarify supernatants by centrifuging them $30 \mathrm{~min}$ at $6000 \times g, 4^{\circ} \mathrm{C}$, in an SLA-3000 rotor. Save supernatants and discard pellets.

4. Determine the total volume of supernatant to be concentrated. Bring the $\mathrm{NaCl}$ concentration to $1 \mathrm{M}$.

DMEM contains $6.8 \mathrm{~g} / \mathrm{liter} \mathrm{NaCl}$, so add $51.6 \mathrm{~g} \mathrm{NaCl}$ per liter of fluid to be concentrated.

5. Add PEG 8000 to a concentration of $8 \%(w / v)$.

6. Stir fluid at $4^{\circ} \mathrm{C}$ overnight.
Norovirus:

Propagation, Quantification, and Genetic Manipulation 
7. Centrifuge fluid $30 \mathrm{~min}$ at $17,000 \times g, 4^{\circ} \mathrm{C}$.

8. Discard supernatant.

\section{Solvent extraction}

9. Resuspend the pellet in $20 \mathrm{ml}$ PBS. Split sample in half. Transfer to 50-ml conical tube.

10. Sonicate for $30 \mathrm{sec}$ (at setting 4.0 for the Sonic Dismembrator).

11. Add an equal volume of Vertrel XF solvent, a non-hazardous freon substitute.

12. Sonicate with microtip at 4.0 for about 1 min to make an emulsion.

13. Centrifuge $10 \mathrm{~min}$ at $2000 \times g, 4^{\circ} \mathrm{C}$.

You should see a top opalescent aqueous phase, an interphase (white), and a lower organic phase.

14. Take the aqueous phase and repeat the solvent extraction one time.

15. Store on ice until gradient is ready.

\section{CsCl gradient purification}

16. Make a step gradient by placing $10 \mathrm{ml}$ of $1.45 \mathrm{~g} / \mathrm{cm}^{3} \mathrm{CsCl}$ in bottom of centrifuge tube, and then very gently overlaying with $10 \mathrm{ml}$ of $1.35 \mathrm{~g} / \mathrm{cm}^{3} \mathrm{CsCl}$.

17. Gently overlay $\sim 18 \mathrm{ml}$ virus-containing solution onto the gradient.

Prepare another tube of same weight for balance.

18. Ultracentrifuge $48 \mathrm{hr}$ at $100,000 \times g, 4^{\circ} \mathrm{C}$.

19. Wipe bottom of tube with $95 \%$ ethanol, drill a hole in the bottom of the tube with a 22-G needle, and collect 1-ml fractions.

20. Determine refractive index (RFI) of each fraction.

21. Dialyze fractions (Zumstein, 1998) with RFI $\sim 1.362$ to 1.373 against two changes of 2-liters of PBS overnight at $4^{\circ} \mathrm{C}$, using an MWCO $10 \mathrm{kDa}$ dialysis membrane.

22. Analyze fractions by running $5 \mu \mathrm{l}$ from each fraction on an SDS-PAGE gel, and Coomassie staining the gel (all procedures described in APPENDIX $3 M$ ) to check the purity.

The capsid protein is $\sim 58 \mathrm{kDa}$ and should be clearly visible.

\section{MURINE NOROVIRUS ENZYME-LINKED IMMUNOSORBENT ASSAY}

The purpose of an enzyme-linked immunosorbent assay (ELISA) is to detect and quantify the presence of proteins, antibodies, and certain other substances in a sample. The antigen is immobilized onto the surface of an ELISA well and then complexed with an antibody. The antibody can be directly conjugated to an enzyme, or a secondary antibody conjugated to an enzyme can be used. The enzyme typically catalyzes a reaction that produces a product that is measurable, most commonly via a color change, to quantify enzyme activity. The purpose of the MNV enzyme-linked immunosorbent assay (ELISA) is to detect and quantify the presence of anti-MNV specific antibodies in a sample (e.g., mouse serum). Positive samples (i.e., containing MNV antibodies) will turn green during the development time, while negative samples remain clear. 


\section{Materials}

Concentrated virus (see Support Protocol 1)

Phosphate-buffered saline (PBS), pH 7.4, sterile (e.g., Life Technologies, cat. no.10010-023)

ELISA wash buffer (see recipe)

ELISA blocking buffer (see recipe)

ELISA III buffer (see recipe)

Sera to be tested, plus known positive and negative control sera

Goat anti-mouse $\operatorname{IgG}, \operatorname{IgA}$, IgM $(\mathrm{H}+\mathrm{L})$, horseradish peroxidase conjugate (Life

Technologies, cat no. A10668)

ELISA substrate buffer (see recipe)

$30 \% \mathrm{H}_{2} \mathrm{O}_{2}$ (Fisher Scientific, cat. no. BP 2633-500)

Stop buffer (0.1 N phosphoric acid): $6.8 \mathrm{ml} 85 \%$ phosphoric acid $(14.7 \mathrm{~N})$ per $500 \mathrm{ml}$ water

Immulon II HB flat-bottomed ELISA plate (Thermo Labsystems)

Repeating and multichannel pipettors with reservoirs

Plate reader

\section{Perform steps 1 to 10 in a biosafety hood}

1. Calculate the number of wells and final volume of virus needed to coat the plate. For each well, dilute 2 to $5 \mu$ l of concentrated virus in phosphate-buffered saline (PBS) in a final volume of $100 \mu 1$.

The optimal concentration of virus for coating per well should be determined in a pilot experiment. We typically coat with $2 \mu \mathrm{l}$ of concentrated $M N V / w e l l$.

2. Use repeating pipettor to distribute $100 \mu \mathrm{l}$ of diluted virus solution/well into each well of a 96-well ELISA plate, and then incubate overnight at $4{ }^{\circ} \mathrm{C}$ covered with aluminum foil.

3. On the next day, flick out virus solution into a biohazard bag, and then wash ELISA plate once with ELISA wash buffer by submerging plate, tapping out any air bubbles.

4. Flick out buffer into a biohazard bag and then blot on a paper towel.

5. Use a multichannel pipettor to add $200 \mu$ l ELISA blocking buffer to each well, and then incubate plate at $37^{\circ} \mathrm{C}$ for $2 \mathrm{hr}$ covered with Parafilm.

6. While plate is blocking, use ELISA III buffer to make serum dilutions.

For screening of sera, use a 1:100 dilution analyzed in duplicate. Do not forget to include a known negative and positive serum.

7. Flick out blocking buffer into a biohazard bag and then wash plates twice with ELISA wash buffer (flicking out buffer into biohazard bag between washes).

Do not let plate dry.

8. Add $100 \mu \mathrm{l}$ of the serum dilution to each well, and then incubate plate for $60 \mathrm{~min}$ at $37^{\circ} \mathrm{C}$ covered in Parafilm.

9. Dilute goat-anti-mouse HRP 1:2000 in ELISA III buffer.

10. Flick out serum dilutions into a biohazard bag and then wash plates four times with ELISA wash buffer (flicking out buffer into biohazard bag between washes).

\section{Do not let plates dry.}


11. Use a multichannel pipettor to add $100 \mu 1$ of diluted secondary antibody per well, and then incubate plate for $1 \mathrm{hr}$ at $37^{\circ} \mathrm{C}$ covered in Parafilm.

12. At the beginning of the incubation periods, thaw one 12-ml aliquot of ELISA substrate buffer per plate at room temperature in the dark.

13. Flick out antibody dilutions and then wash plates four times with ELISA wash buffer.

Do not let plate dry.

14. Add $1 \mu \mathrm{l}$ of $30 \%$ hydrogen peroxide per $1 \mathrm{ml}$ of ELISA substrate buffer. Pour into a plastic reservoir.

15. Use a multichannel pipettor to add $100 \mu 1$ of ELISA substrate buffer to each well and incubate for up to $10 \mathrm{~min}$ at room temperature.

16. Stop the assay when your negative control begins to turn color, or after $10 \mathrm{~min}$ (whichever comes first), by adding $100 \mu 1$ stop buffer to each well.

17. Measure absorption at $415 \mathrm{~nm}$ on ELISA reader.

You can use $405 \mathrm{~nm}$ if $415 \mathrm{~nm}$ is absent. Numbers are expressed as optical density (OD). Compare the OD value of your sample to the positive and negative control values for data interpretation.

\section{DNA-BASED, POL II-DRIVEN GENERATION OF RECOMBINANT MURINE NOROVIRUS}

Reverse genetics is a powerful tool used to recover a genetically defined recombinant virus from a cDNA clone, and can be utilized to examine the effect of mutations on the virus life cycle in vitro and in vivo. Several reverse genetics systems have been described (see also Basic Protocol 4 and Alternate Protocol 2). This protocol is based on a publication by Ward et al. (2007). A DNA polymerase II promoter drives expression of viral cDNA after transfection of a DNA plasmid containing the full-length MNV genome into HEK293T cells. This usually yields about $10^{3} \mathrm{pfu} / \mathrm{ml}$ of MNV. The recombinant virus is subsequently amplified in RAW 264.7 cells to yield between $10^{6}$ and $10^{7} \mathrm{pfu} / \mathrm{ml}$ of MNV in RAW 264.7 cells.

\section{Materials}

Full-length MNV-containing plasmid (pMNV; available via materials transfer agreement from Dr. Herbert Virgin,virgin@wustl.edu)

EGFP-expressing plasmid as control for transfection efficiency

Opti-MEM I medium (Invitrogen)

Transfection reagent (Fugene HD; Promega)

293 T cells (ATCC no. CRL-3216) growing in culture (low passage number works better)

DMEM-10 medium (see recipe)

RAW 264.7 cells (ATCC no. TIB-71; if viruses are going to be passaged to RAW cells)

QIAamp viral RNA kit (Qiagen)

Qiagen OneStep RT-PCR kit

RNasin (Promega)

$10 \mathrm{mM}$ dNTP mix (APPENDIX 2A)

Forward primer (GTGCGCAACACAGAGAAACG)

Reverse primer (CGGGCTGAGCTTCCTGC)

Nuclease-free $\mathrm{H}_{2} \mathrm{O}$ (APPENDIX 2A, or purchase, e.g., from Invitrogen)

QIAquick PCR purification kit (Qiagen) 
25-, 75-, and $175-\mathrm{cm}^{2}$ culture flasks

15 -ml screw-cap tubes

15-ml conical centrifuge tubes (e.g., BD Falcon)

PCR tubes

Spectrophotometer

Sequencing facility

Additional reagents and equipment for determining viral titer by $\mathrm{TCID}_{50}(\mathrm{Basic}$

Protocol 5) or plaque assay (Alternate Protocol 3), agarose gel electrophoresis

(Voytas, 2000), and spectrophotometric quantitation of DNA (Gallagher, 2011)

NOTE: All steps are carried out at room temperature. Media should be warmed to $37^{\circ} \mathrm{C}$ or equilibrated to room temperature. Transfect 293T cells with MNV plasmid

1. Dilute $1.5 \mu \mathrm{g}$ MNV plasmid in $94 \mu \mathrm{l}$ Opti-MEM I in a $1.5-\mathrm{ml}$ microcentrifuge tube.

Opti-MEM I used for the transfection reaction mix should NOT have added serum or antibiotics

Include the EGFP-expressing plasmid as a control for transfection efficiency.

2. Add $6 \mu$ l Fugene HD to the Opti-MEM-plasmid mix and briefly vortex (for about $2 \mathrm{sec}$ ) on high. Spin down transfection mix for $10 \mathrm{sec}$ at $8000 \times g$.

The ratio of plasmid to Fugene HD is usually 1:4, but you can try other ratios to determine the best combination for your plasmid. Fugene HD sticks to plastics so avoid touching the plastic wall of the tube by pipetting directly into the solution. Take Fugene HD directly from the refrigerator, vortex before use, and put it back after pipetting. Warming Fugene $H D$ is not necessary.

3. Incubate solutions for $15 \mathrm{~min}$ at room temperature.

Do not to exceed $25 \mathrm{~min}$. If you are transfecting many plasmids, make sure you can proceed with the first sample after a 15-min incubation.

4. In the meantime, harvest $293 \mathrm{~T}$ cells. Aspirate the medium and add $10 \mathrm{ml}$ of fresh DMEM-10 medium. Dislodge the cells by hitting the flask. Centrifuge cells $5 \mathrm{~min}$ at $200 \times g$, room temperature, remove the supernatant, and resuspend cells at $1 \times$ $10^{7}$ cells $/ \mathrm{ml}$ in DMEM- 10 .

Healthy 2937 cells are easily dislodged from the flask. If the cells have a problem dislodging, then you may want to use a fresh batch. The effect of trypsin on 2937 is not yet established, so you should stay away from it during this step.

5. Add $100 \mu \mathrm{l}$ of the cell suspension $\left(1 \times 10^{6}\right.$ cells $)$ to the centrifuge tube containing transfection mix and incubate for 5 to $10 \mathrm{~min}$.

6. Label $75-\mathrm{cm}^{2}$ flasks and add $10 \mathrm{ml}$ of DMEM-10 culture medium to each flask.

It is OK for 2937 culture medium to have antibiotics at all times.

7. Transfer transfection mix with cells into $75-\mathrm{cm}^{2}$ flask. Rinse centrifuge tube with $1 \mathrm{ml}$ medium from the prepared $75-\mathrm{cm}^{2}$ flask and add to flask. Incubate for at least $48 \mathrm{hr}$ at $37^{\circ} \mathrm{C}$ with $5 \% \mathrm{CO}_{2}$.

If incubation time will be 72 to $96 \mathrm{hr}$, replace medium on $293 \mathrm{~T}$ cells with $10 \mathrm{ml}$ culture medium the next day.

Murine Norovirus: Propagation, Quantification, and Genetic Manipulation

15K.2.10

\section{Passage onto RAW 264.7 cells (liquid passage)}

8. The day before passage, plate $4 \times 10^{7}$ RAW 264.7 cells per $175-\mathrm{cm}^{2}$ flask.

9. Freeze $293 \mathrm{~T}$ cells at $-80^{\circ} \mathrm{C}$ and thaw the frozen cells at $37^{\circ} \mathrm{C}$.

10. Repeat step 9. 
11. Transfer lysate into $15-\mathrm{ml}$ screw-cap tube.

12. Spin 5 min at $2500 \times g, 4^{\circ} \mathrm{C}$.

13. Infect RAW 264.7 cells in $175-\mathrm{cm}^{2}$ flask with $5 \mathrm{ml}$ of cleared $293 \mathrm{~T}$ lysate (from step 12) and $25 \mathrm{ml}$ DMEM-10 medium.

14. Incubate for at least $48 \mathrm{hr}$ at $37^{\circ} \mathrm{C}$ with $5 \% \mathrm{CO}_{2}$ or until cytopathic effect is seen.

\section{Harvest recombinant viruses}

15. Freeze RAW 264.7 cells at $-80^{\circ} \mathrm{C}$ and thaw the frozen cells at $37^{\circ} \mathrm{C}$.

16. Repeat step 15.

17. Transfer lysate into 50-ml conical centrifuge tubes.

18. Spin 5 min at $2500 \times g, 4^{\circ} \mathrm{C}$.

19. Save supernatant. For short-term storage ( 1 to 2 days) store at $4^{\circ} \mathrm{C}$. Otherwise, freeze at $-80^{\circ} \mathrm{C}$.

\section{Determine titer of recombinant virus}

20. Use plaque assay (see Alternate Protocol 3) or $\mathrm{TCID}_{50}$ (see Basic Protocol 5) to confirm the presence of viruses both in the cleared lysates from 293T and RAW 264.7 cells.

\section{Plaque purification (optional)}

21. Pick a plaque from a plate prepared in step 20 with a sterilized glass Pasteur pipet by punching the pipet through the overlay into the plaque.

Pick up to five plaques and freeze up to four at $-80^{\circ} \mathrm{C}$ in case you need more plaques to sequence and get the desired virus.

22. Transfer the agar plug into $500 \mu 1$ DMEM-10 medium and vortex.

23. Infect RAW 264.7 cells in a $25-\mathrm{cm}^{2}$ flask containing $5 \mathrm{ml}$ culture medium plus $200 \mu 1$ of the medium containing the agar plug.

24. Repeat step 14.

25. Harvest virus as described in steps 15 to 19.

26. Extract RNA from $140 \mu l$ virus lysate using the QIAamp viral RNA kit according to the manufacturer's recommendations.

27. Prepare a 50- $\mu 1$ RT-PCR reaction with the following components in a PCR tube for reverse transcription (RT) of viral RNA to cDNA using the Qiagen OneStep RT-PCR kit.

$10.00 \mathrm{ml} 5 \times$ Qiagen OneStep reaction buffer

$0.50 \mu 1$ RNasin

$2.00 \mu 110 \mathrm{mM}$ dNTP mix

$2.00 \mu 125 \mu \mathrm{M}$ forward primer

$2.00 \mu \mathrm{l} 25 \mu \mathrm{M}$ reverse primer

$2.00 \mu l$ Qiagen Enzyme mix (from OneStep kit)

$26.50 \mu 1$ nuclease-free $\mathrm{H}_{2} \mathrm{O}$

$5.00 \mu \mathrm{l}$ RNA template (step 26).

28. Centrifuge the PCR tube briefly ( $\sim 5 \mathrm{sec})$ to collect the reaction mixture at the bottom of the tube. 
ALTERNATE PROTOCOL 2

29. Place the tube in a thermal cycler and perform PCR using the following parameters:

$\begin{array}{llll}1 \text { cycle: } & 30 \mathrm{~min} & 50^{\circ} \mathrm{C} & \text { (reverse transcription) } \\ 1 \text { cycle: } & 15 \mathrm{~min} & 95^{\circ} \mathrm{C} & \text { (initial denaturation) } \\ 40 \text { cycles: } & 30 \mathrm{sec} & 94^{\circ} \mathrm{C} & \text { (denaturation) } \\ & 15 \mathrm{sec} & 55^{\circ} \mathrm{C} & \text { (annealing) } \\ & 1 \mathrm{~min} & 72^{\circ} \mathrm{C} & \text { (extension) } \\ 1 \text { cycle: } & 10 \mathrm{~min} & 72^{\circ} \mathrm{C} & \text { (final extension) } \\ 1 \text { cycle: } & \text { Indefinitely } & 4^{\circ} \mathrm{C} & \text { (hold). }\end{array}$

30. Run $5 \mu l$ of the PCR reaction on a $1 \%$ agarose gel (Voytas, 2000) to confirm your cDNA.

31. Remove primers from the PCR product using QIAquick PCR purification kit according to the manufacturer's recommendations.

32. Determine the concentration of your cDNA with a spectrophotometer.

33. Send cDNA sample with primers for sequencing according to the sequencing company's instructions.

34. Compare your sequencing results with published MNV sequences using the basic local alignment search tool (BLAST) on the NCBI Web site.

\section{DNA-BASED, T7-DRIVEN GENERATION OF RECOMBINANT MNV}

The recovery of murine norovirus (MNV) from transcripts generated from cDNA, in a process driven by $\mathrm{T} 7$ polymerase, is a robust, reproducible, and rapid method that yields high recovery titers of infectious MNV (Fig. 15K.2.1). The protocol described below comprises seeding of transfectable cells permissive for MNV replication, infection with recombinant fowlpox virus (FPV-T7) for the expression of T7 RNA polymerase (see Support Protocol 3), and subsequent transfection of cDNA containing the MNV genome under the control of a T7 RNA polymerase promoter (Fig. 15K.2.2). After an appropriate incubation period, the infectious MNV particles can be titrated in suitably susceptible cells. A video is available at $h t t p: / / w w w . j o v e . c o m / v i d e o / 4145 /$ reverse-genetics-mediatedrecovery-of-infectious-murine-norovirus.

\section{Materials}

Cultures of transfectable cells permissive for MNV replication, i.e., baby hamster kidney cells (BHK), BSR-T7 (BHK-21-derived cells expressing recombinant T7-polymerase), human embryonic kidney cells (HEK-293T), human hepatocellular carcinoma cells (Huh7), or African green monkey cells (COS-7)

Titered stock of FPV-T7 (Support Protocol 3)

Dulbecco's modified Eagle's medium (DMEM; Life Technologies) with 10\% fetal bovine serum (FBS) and no antibiotics

Opti-MEM I medium (Invitrogen)

cDNA clone of MNV under the control of a T7 RNA polymerase promoter (i.e., pT7:MNV-1 3'Rz; full-length MNV-containing plasmid has been produced in Ian Goodfellow's laboratory and its generation has been described in Chaudhry et al., 2007, and Yunus et al., 2010)

Lipofectamine 2000 (Invitrogen)

35-mm dish

Additional reagents and equipment for basic cell culture techniques including trypsinization and cell counting (Phelan, 2006)

1. Trypsinize (Phelan, 2006) a confluent flask of BHK or BSR-T7 cells. For transfections the following day, seed (Phelan, 2006) $7.5 \times 10^{5}$ cells per $35-\mathrm{mm}$ dish, using 


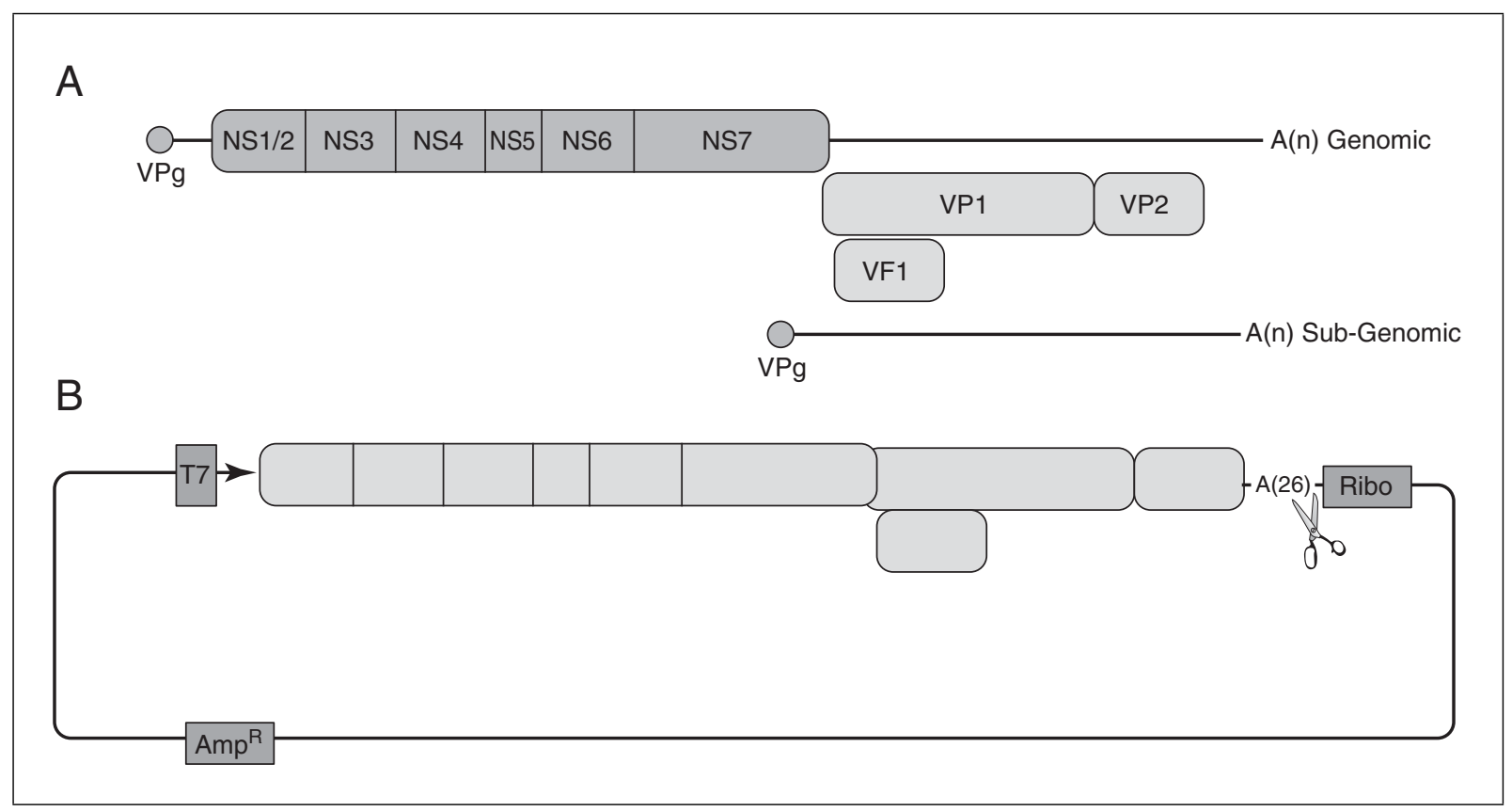

Figure 15K.2.1 Genome organization of MNV. (A) MNV encodes four open reading frames (ORFs). ORF1 is translated into a precursor polyprotein that is autocatalytically cleaved to release at least six nonstructural proteins, NS1-7. ORF2 encodes the major capsid protein VP1, while ORF3 encodes the minor capsid protein VP2. ORF4 overlaps with ORF2 at $a+1$ frame and encodes VF1. During replication, MNV translates from a genomic and subgenomic RNA, both of which include VPg at the $5^{\prime}$ end and a poly $(A)$ tail at the $3^{\prime}$ end of varying lengths. (B) Schematic of the recovery of infectious MNV from cDNA plasmid (representative example, pT7:MNV-1 3'Rz). The MNV cDNA sequence is downstream of the T7 promoter sequence, which allows for the T7-driven transcription of MNV. At the $3^{\prime}$ extremity, MNV cDNA is fused to a 26-nucleotide long poly(A) tail. Downstream of MNV cDNA, the sequence for a self-cleaving ribozyme is fused to generate an authentic $3^{\prime}$ end.

antibiotic-free DMEM supplemented with $10 \%$ FBS. Gently rock the dish to ensure even distribution of cells and incubate the plates at $37^{\circ} \mathrm{C}$ (with $5 \%$ to $10 \% \mathrm{CO}_{2}$ ) to settle overnight. If you wish to perform the transfection on the same day, seed $1.5 \times$ $10^{6}$ cells and leave cells to adhere for a 2 - to 3 -hr period at $37^{\circ} \mathrm{C}\left(5 \%\right.$ to $\left.10 \% \mathrm{CO}_{2}\right)$ prior to proceeding to the next step.

This protocol is optimized for the use of BHK or BHK-derived BSR-T7 cells. Further optimization is necessary if other transfectable cell lines are to be used. Parameters to consider include cell seeding density, multiplicity of infection of FPV to be used, amount of plasmid to be transfected, and incubation period following transfection.

2. Remove the growth medium from the cells and add $700 \mu 1$ of FPV-T7 at a multiplicity of infection of $0.5 \mathrm{pfu} / \mathrm{cell}$. For optimal recoveries in BHK and BSR-T7 cells, ensure that FPV is diluted to infect at a multiplicity of infection of $0.5 \mathrm{pfu} / \mathrm{cell}$.

FPV-T7 should be prepared and titrated in primary chicken embryo fibroblast (CEF) cells, as detailed in Support Protocol 3. The optimal amount of FPV-T7 must be determined for each cell line, as the rate of infection differs.

The left-over FPV-T7 aliquot that has been used for recoveries should be marked before freezing again, as the titer of the aliquot might have dropped. We suggest combining several aliquots that have been thawed once and aliquotting them into new aliquots. The virus titer for this stock of recycled FPV-T7 should be determined before use.

3. Leave cells for $1 \mathrm{hr}$ at $37^{\circ} \mathrm{C}$ (with $5 \%$ to $10 \% \mathrm{CO}_{2}$ ) to allow infection with FPV-T7. Add $2 \mathrm{ml}$ of antibiotic- free DMEM supplemented with 10\% FBS, and leave cells at $37^{\circ} \mathrm{C}$ (with $5 \%$ to $10 \% \mathrm{CO}_{2}$ ) for a further $1 \mathrm{hr}$ to allow FPV to express T7 RNA polymerase.

Animal RNA Viruses

15K.2.13 


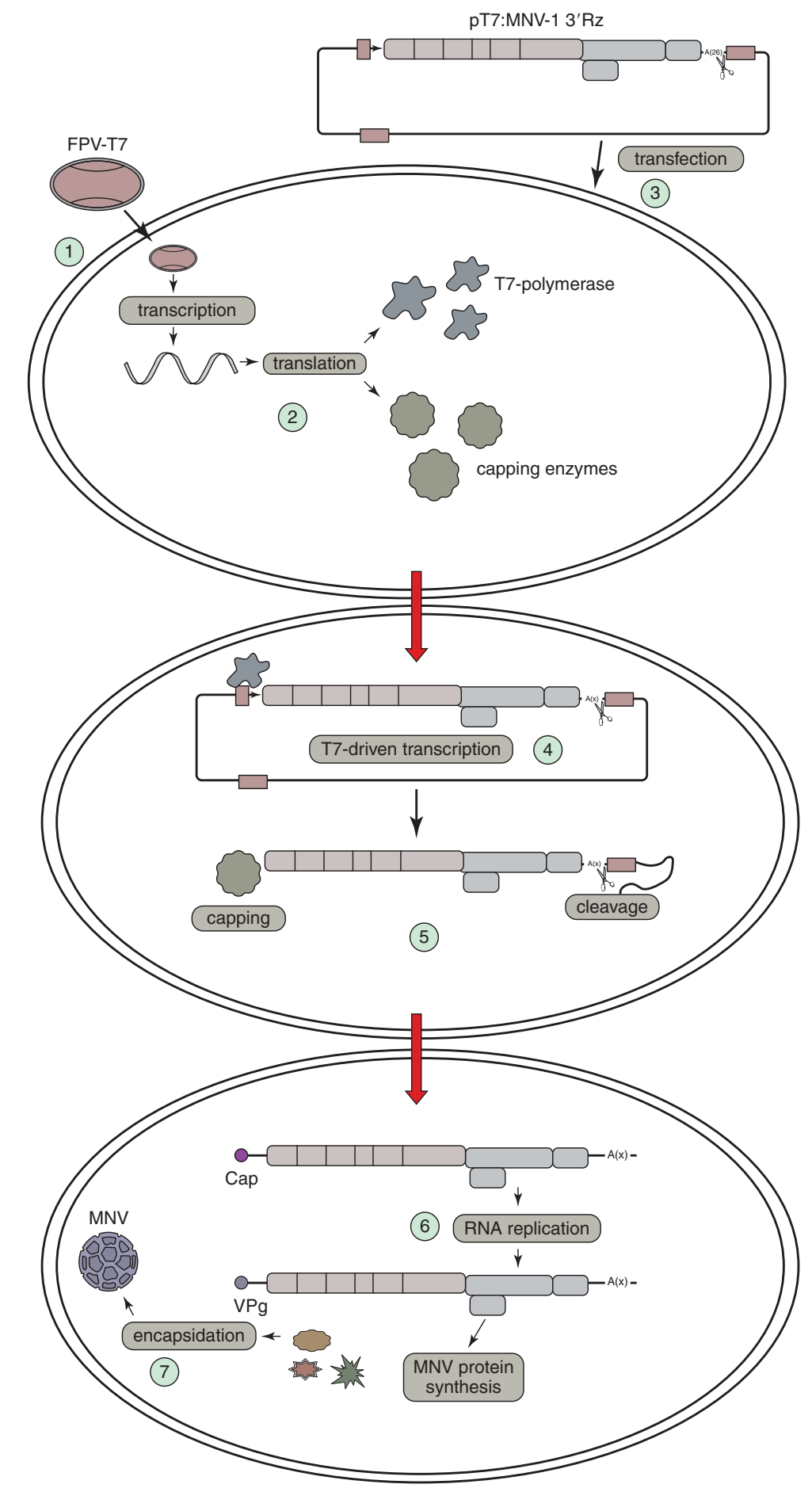

Figure 15K.2.2 Schematic of recovery procedure. (1) Transfectable cells (i.e BSR-T7 or BHK) are infected with FPV-T7. (2) Following cell entry, FPV-T7 transcription and translation results in the production of T7 RNA polymerase. (3) After cells are left to incubate for $2 \mathrm{hr}$ to allow for the production of T7 RNA polymerase, pT7:MNV-1 3'Rz is transfected using Lipofectamine 2000. (4) pT7:MNV-1 $3^{\prime} \mathrm{Rz}$ is transcribed in the cytoplasm, driven by the FPV-T7 encoded T7- RNA polymerase, to produce MNV RNA transcripts. (5) The self-cleaving $\delta$-ribozyme that is encoded by $\mathrm{pT7}: \mathrm{MNV}-13^{\prime} \mathrm{Rz}$ generates an authentic $3^{\prime}$ end. It is possible that capping enzymes produced

Norovirus: Propagation, Quantification, and Genetic Manipulation

15K.2.14 by FPV-T7 are able to cap MNV RNA transcripts. (6) Capped MNV RNA transcripts are translated for the production of MNV proteins. VPg linked MNV RNA transcripts undergo replication. (7) Nascent MNV RNA produced can be encapsidated to produce full infectious virus. Cells subjected to freeze-thaw cycles can facilitate virus release. Virus yields can be subsequently titered by means of end-point dilution assays, or plaque assays. 


\begin{tabular}{ll} 
Cell type $^{a}$ & Titers $^{b}$ with pT7:MNV-1 ${ }^{\prime}$ Rz \\
\hline BHK & $3.4 \times 10^{4} \mathrm{TCID}_{50} / \mathrm{ml}^{c}$ \\
BSR-T7 & $3.4 \times 10^{4} \mathrm{TCID}_{50} / \mathrm{ml}$ \\
HEK 293T & $6.0 \times 10^{4} \mathrm{TCID}_{50} / \mathrm{ml}$ \\
Huh 7.5 & $2.4 \times 10^{4} \mathrm{TCID}_{50} / \mathrm{ml}$ \\
\hline
\end{tabular}

${ }^{a}$ Cells transfected with pT7:MNV-1 3'Rz.

${ }^{b}$ Virus yield determined $24 \mathrm{hr}$ post transfection.

${ }^{c}$ Titers performed in triplicate and expressed as $\mathrm{TCID}_{50} / \mathrm{ml}$.

It is important that no antibiotics be present in the growth medium, as this may interfere with the lipofection process.

4. To prepare the transfection mixture, combine $100 \mu \mathrm{l}$ of Opti-MEM I containing $1 \mu \mathrm{g}$ of MNV cDNA clone that is under the control of a T7 RNA polymerase promoter, with $100 \mu$ l Opti-MEM I containing $4 \mu 1$ of Lipofectamine 2000. Mix the resultant mixture thoroughly by gently pipetting up and down around 15 times. Allow 20 min at room temperature for Lipofectamine 2000 to form a complex with the cDNA.

5. Aspirate the growth medium containing unattached virus off the cells (see step 3) and gently wash once with $2 \mathrm{ml}$ of antibiotic-free DMEM supplemented with $10 \%$ FBS. Then add $3 \mathrm{ml}$ of antibiotic-free DMEM supplemented with 10\% FBS to cover the cells.

6. Add the transfection mix (from step 4) in a dropwise manner to the cell monolayer (from step 5). To ensure even distribution of the cDNA, gently rock the plates before placing them at $37^{\circ} \mathrm{C}$ (with $5 \%$ to $10 \% \mathrm{CO}_{2}$ ).

Plasmid pT7:MNV-1 3'Rz, containing the full MNV-1 cDNA genome sequence, produces optimal titers after $24 \mathrm{hr}$ incubation, though other strains may require a longer incubation period.

As a reference, $M N V-1$ cDNA clone pT7:MNV-1 3'Rz requires only $24 \mathrm{hr}$ to produce virus titers above $10^{4} \mathrm{TCID}_{50} / \mathrm{ml}$ (Table 15K.2.1). For other strains (i.e., MNV-3), or viruses containing deleterious mutations affecting replication, longer incubation periods may be required for optimal yields (Arias et al., 2012).

7. Freeze cells at $-80^{\circ} \mathrm{C}$. Once thawed, centrifuge cells $5 \mathrm{~min}$ at $1000 \times g$, room temperature, to pellet the cellular debris.

The virus-containing supernatant can be aliquotted and stored indefinitely at $-80^{\circ} \mathrm{C}$. A frozen aliquot should be thawed and used to titrate the recoveries.

\section{PREPARATION OF A FPV-T7 STOCK REQUIRED FOR REVERSE GENETICS}

Preceding the recovery of MNV from genomic cDNA is the generation of a wellcharacterized FPV-T7 virus stock. Expression of recombinant T7 RNA polymerase in cells infected with FPV-T7 will drive the synthesis of replication-competent capped viral transcripts from cDNA. The FPV-T7 strain used was initially generated by Dr Mike Skinner, Imperial College London, and is readily available via MTA (Britton et al., 1996).

This approach will typically produce MNV-1 at a titer of $>10^{4} \mathrm{TCID}_{50} / \mathrm{ml}$ after $24 \mathrm{hr}$. Recovery titers from other commonly used transfectable cell lines are highlighted in Table 15K.2.1. High-titer MNV stocks can then be produced by infecting a susceptible cell line such as RAW 264.7 or BV-2 cells. 


\section{Materials}

Primary chicken embryonic fibroblast cells (CEFs)

Dulbecco's modified Eagle's medium (DMEM; Life Technologies), supplemented with $10 \%$ fetal bovine serum (FBS) and $1 \times$ penicillin/streptomycin

FPV-T7 inoculating stock (obtained via MTA from Dr. Mike Skinner, Imperial College London; m.skinner@imperial.ac.uk)

Large volume flasks (175- or $\left.225-\mathrm{cm}^{2}\right)$

Additional reagents and equipment for basic cell culture techniques including trypsinization and cell counting (Phelan, 2006)

1. Trypsinize a flask of chicken embryo fibroblasts (CEFs) primary cells and seed them at $1 \times 10^{5}$ cells/ml (Phelan, 2006).

Typically, large-volume flasks (175- or 225- $\mathrm{cm}^{2}$ ) are seeded with CEFs to facilitate the recovery of high volumes of FPV-T7. This seeding density equates to $\sim 5 \times 10^{6}$ cells in a $175-\mathrm{cm}^{2}$ flask.

2. When cells reach $100 \%$ confluence, infect them with FPV-T7 at a multiplicity of infection of $\sim 1 \mathrm{pfu} /$ cell and incubate for $1 \mathrm{hr}$ at $37^{\circ} \mathrm{C}$ in the presence of $5 \%$ to $10 \%$ $\mathrm{CO}_{2}$.

3. Remove the inoculum and add DMEM supplemented with $10 \%$ FBS and $1 \times$ penicillin/streptomycin to overlay the cells. Incubate the infected cell cultures at $37^{\circ} \mathrm{C}$ in the presence of $5 \%$ to $10 \% \mathrm{CO}_{2}$ until complete cytopathic effect is observed.

A small mock-infected cell culture should be carried out in parallel to identify cytopathic effect in infected cultures.

For a $175-\mathrm{cm}^{2}$ flask, a volume of $20 \mathrm{ml}$ is recommended to cover the cells to enable the recovery of higher virus titers. Complete cytopathic effect is observed within 48 and $72 \mathrm{hr}$ post-infection. Typically, cytopathic effect results in the development of granular cell morphology (Somogyi et al., 1993). A small mock-infected culture might be useful to distinguish cytopathic effect in the infected cultures.

4. Freeze-thaw the cell cultures twice to facilitate the release of virus particles to the supernatant.

5. Remove the cell debris from the lysates by centrifugation for $5 \mathrm{~min}$ at $600 \times g, 4^{\circ} \mathrm{C}$.

Virus preparations should not be filtered to clarify them, as FPV diameter is around 260 to $280 \mathrm{~nm}$ (larger than pore-diameter size in 0.2- $\mu \mathrm{m}$ filters).

6. Recover the supernatant and aliquot in different tubes that can be stored indefinitely at $-80^{\circ} \mathrm{C}$.

BASIC PROTOCOL 4

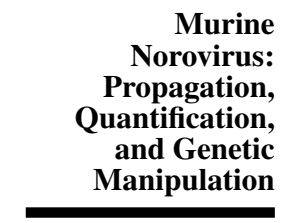

15K.2.16

\section{RNA-BASED GENERATION OF RECOMBINANT MURINE NOROVIRUS}

Infectious MNV from cDNA is efficiently recovered via in vitro transcription and subsequent in vitro capping. The resulting capped RNA transcripts are then transfected into cells to recover infectious MNV. Transcripts are transfected into either BV-2 or BSRT7 cells. BSRT7 or parental BHK cells are used to test the specific infectivity of the RNA, as the cells are not permissive to re-infection, and virus yields represent those from a single growth cycle. BV-2 cells are used when minimal passage in cell culture is required for a cDNA clone that is known to be infectious.

Typically, Neon (Life Technologies)-mediated transfection of BV-2 cells can yield around $1 \times 10^{6} \mathrm{TCID}_{50} / \mathrm{ml} \mathrm{MNV}$ at $24 \mathrm{hr}$ post-transfection and up to $1 \times 10^{9} \mathrm{TCID}_{50} / \mathrm{ml}$ at $72 \mathrm{hr}$ post-transfection, although this effectively constitutes the first passage of the virus. Recovery using BSR-T7 cells generally yields $1 \times 10^{6} \mathrm{TCID}_{50} / \mathrm{ml}$ of $\mathrm{MNV}$ at $48 \mathrm{hr}$ post-transfection. 
A video for the generation of recombinant MNV can be found at http://www.jove .com/video/4145/reverse-genetics-mediated-recovery-of-infectious-murine-norovirus

\section{Materials}

MNV cDNA (pT7:MNV 3'Rz) or plasmid containing recombinant MNV cDNA

NheI restriction enzyme (NEB, cat. no. R0131S)

GFX PCR DNA Gel Band Purification Kit (GE Healthcare, cat. no. 28-9034-70)

MEGAscript T7 Kit (Life Technologies, cat. no. AM1334) including reagents tabulated in Table 15K.2.3

2 U/ $\mu 1$ DNase I, RNase-free (NEB, cat. no. M0303S) and DNase I buffer

Lithium chloride $(\mathrm{LiCl})$ precipitation solution (Life Technologies, cat. no. AM9480)

$70 \%$ ethanol

RNA storage solution (Life Technologies, cat. no. AM7000)

ScriptCap m7G Capping System (Epicentre Biotechnologies, cat. no. SCCE0610)

Neon transfection system (Life Technologies, cat. no. MPK5000)

Neon transfection system kit (Life Technologies, cat. no. MPK1025)

Opti-MEM I (Life Technologies, cat. no. 31985070)

Lipofectamine 2000 Transfection Reagent (Life Technologies, cat. no. 11668-027)

BV-2 cells (Blasi et al., 1990)

BV-2 medium: Dulbecco's Modified Eagle Medium (DMEM) supplemented with $10 \%$ fetal bovine serum (FBS), $2 \mathrm{mM}$ L-glutamine, and $1 \times$ penicillin/streptomycin (omit antibiotics where instructed)

Phosphate-buffered saline (PBS), pH 7.4, sterile (e.g., Life Technologies, cat. no.10010-023)

Neon transfection system (Life Technologies, cat. no. MPK5000)

Neon transfection system 10- $\mu 1$ kit (Life Technologies, cat. no. MPK1025)

BSR-T7 cells (available via materials transfer agreement from Prof. Dr. Karl-Klaus Conzelmann; conzelma@lmb.uni-muenchen.de)

Lipofectamine 2000 (Invitrogen)

Tabletop centrifuge

6-well culture plates

15-ml conical tubes (e.g., BD Falcon)

35-mm culture dish

Additional reagents and equipment for quantification of nucleic acids (Gallagher, 2011), agarose gel electrophoresis of RNA (Voytas, 2000; performed in the same way as for DNA but using RNase-free reagents), and basic cell culture techniques including trypsinization and cell counting (Phelan, 2006), and plaque assay (Alternate Protocol 3) or TCID $_{50}$ assay (Basic Protocol 5)

NOTE: All protocol steps must be performed using RNase-free water.

\section{Synthesis of infectious capped MNV transcripts}

1. Digest 5 to $10 \mu \mathrm{g}$ of the plasmid containing the wild-type MNV cDNA (pT7:MNV $3^{\prime} \mathrm{Rz}$ ) or recombinant MNV cDNA with NheI to obtain linear DNA. Table 15K.2.2 shows a typical reaction setup for NheI digestion.

Table 15K.2.2 Reaction Setup for Nhel Linearization of MNV cDNA

\begin{tabular}{lll}
\hline Components & Final concentration & Per reaction $(\mu \mathrm{l})$ \\
\hline MNV cDNA (pT7:MNV 3'Rz) & $100 \mathrm{ng} / \mu \mathrm{l}$ & Varies \\
10× NEBuffer 2.1 & $1 \times$ & 10 \\
NheI $(10 \mathrm{U} / \mu \mathrm{l})$ & $0.2 \mathrm{U} / \mu \mathrm{l}$ & 2 \\
Water & To $100 \mu \mathrm{l}$ & Varies (to $100 \mu \mathrm{l})$ \\
\hline
\end{tabular}




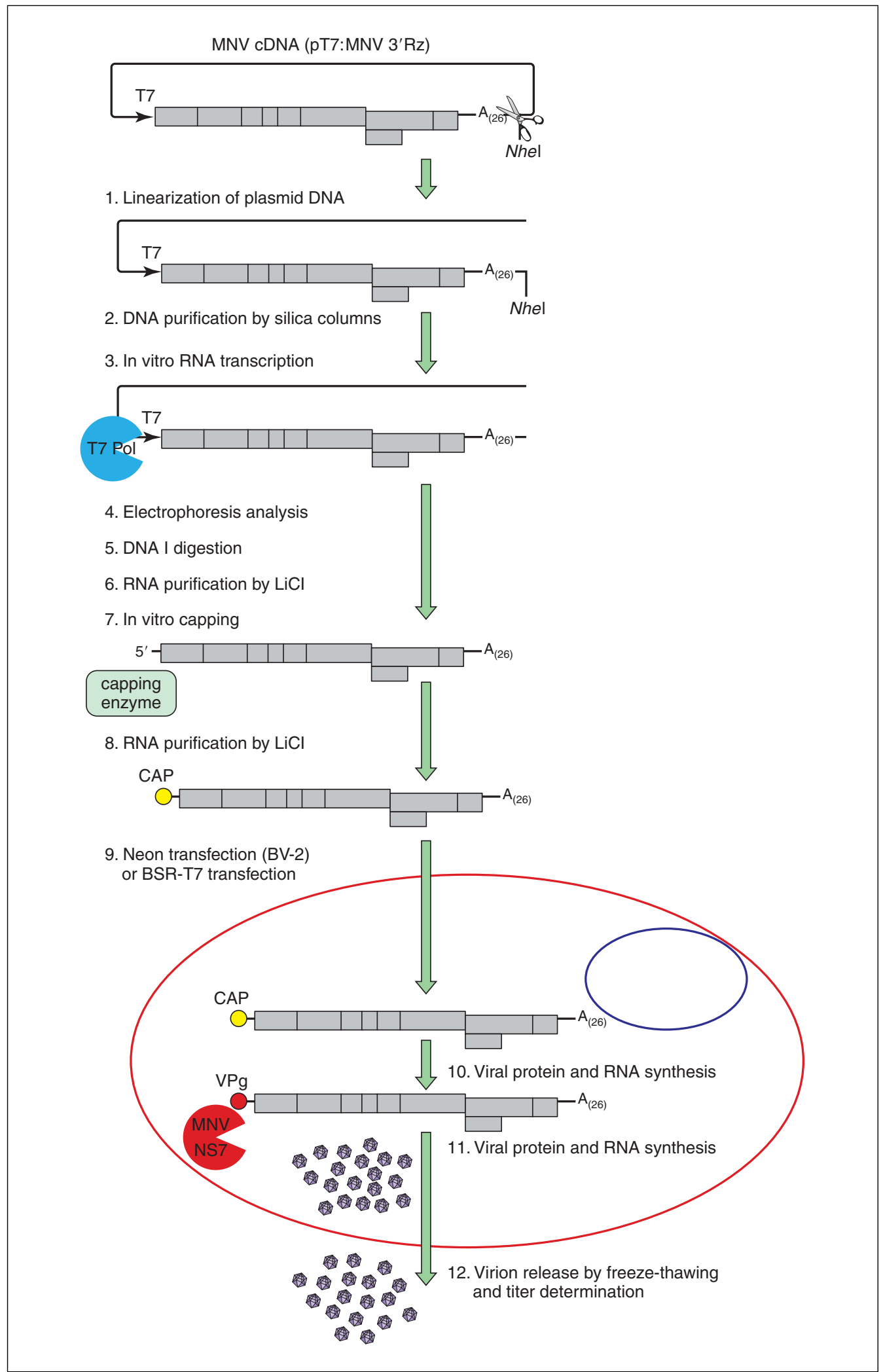

Figure 15K.2.3 (legend appears on next page)

Murine Norovirus: Propagation, Quantification, and Genetic Manipulation

15K.2.18
NheI recognizes a unique restriction site after the $3^{\prime}$-end poly $(A)$ tail of the $M N V$ genome; thus, it defines the $3^{\prime}$ end of transcription with minimal addition of nucleotides to the $3^{\prime}$ end of genome (Fig. 15K.2.3).

2. Incubate the reaction mixture at $37^{\circ} \mathrm{C}$ for $3 \mathrm{hr}$. Purify the linearized plasmid using silica columns (e.g., GFX PCR DNA Gel Band Purification Kit from GE 
Table 15K.2.3 Reaction Setup for In Vitro Transcription of Linearized MNV cDNA

\begin{tabular}{lll}
\hline Components & Final concentration & Per reaction $(\mu \mathrm{l})$ \\
\hline 1 M HEPES, pH 7.5 & $100 \mathrm{mM}$ & 5 \\
$320 \mathrm{mM}$ magnesium acetate & $32 \mathrm{mM}$ & 5 \\
$400 \mathrm{mM}$ DTT & $40 \mathrm{mM}$ & 5 \\
$20 \mathrm{mM}$ spermidine & $2 \mathrm{mM}$ & 5 \\
$100 \mathrm{mM}$ ATP & $7.5 \mathrm{mM}$ & 3.75 \\
$100 \mathrm{mM}$ CTP & $7.5 \mathrm{mM}$ & 3.75 \\
100 mM GTP & $7.5 \mathrm{mM}$ & 3.75 \\
100 mM UTP & $7.5 \mathrm{mM}$ & 3.75 \\
Pyrophosphatase $(0.1 \mathrm{U} / \mu \mathrm{l})$ & $0.002 \mathrm{U} / \mu \mathrm{l}$ & 1 \\
RNaseOUT RNase inhibitor $(40 \mathrm{U} / \mu \mathrm{l})$ & $1.6 \mathrm{U} / \mu \mathrm{l}$ & 2 \\
Water & & 2 (to $50 \mu \mathrm{l})$ \\
Linearized DNA & $20 \mathrm{ng} / \mu \mathrm{l}$ & 5 \\
Recombinant T7 RNA polymerase $(0.5 \mathrm{mg} / \mathrm{ml})$ & $50 \mathrm{ng} / \mu \mathrm{l}$ & 5 \\
\hline
\end{tabular}

Healthcare, used according to the manufacturer's instructions) and elute in $50 \mu 1$ water.

The quality of linearized DNA is important for subsequent in vitro RNA synthesis. Incomplete linearization or RNase contamination in the eluate will compromise the final RNA yield and integrity, and, as such, lead to failure to generate infectious virions. We recommend comparing $100 \mathrm{ng}$ of digested and undigested DNA on an agarose gel (Voytas, 2000) to ensure complete digestion prior to purification.

3. In vitro transcribe the linearized MNV cDNA using T7 RNA polymerase as described below (Yunus et al., 2010).

Many commercial kits are available for this purpose and provide a reproducible method for synthesis of large amounts of RNA, such as MEGAScript (Life Technologies) and RiboMAX (Promega). Ensure that all equipment used, such as microcentrifuge tubes, are certified RNase free, and use filter tips throughout this protocol. Table 15K.2.3 shows a typical reaction setup (50 $\mu \mathrm{l}$ in total; add the reagents in the order indicated).

Addition of pyrophosphatase (see Table 15K.2.3) is optional, but without pyrophosphatase the reaction mixture will become cloudy due to the formation of free pyrophosphate. This can be removed prior to precipitation by centrifugation 1 min at 12,000 $\times$ $g$ and collecting the supernatant.

4. Incubate the reaction mixture at $37^{\circ} \mathrm{C}$ for 2 to $5 \mathrm{hr}$. Load $0.5 \mu \mathrm{l}$ or less of the RNA transcription reaction on an agarose gel and electrophorese (Voytas, 2000;

Figure 15K.2.3 (image appears on previous page) Overview of the protocol for the recovery of infectious MNV from RNA transcribed and capped in vitro. The plasmid pT7:MNV $3^{\prime} R z$ is linearized immediately downstream of the MNV genomic sequence using Nhel restriction enzyme (step 1). After DNA purification (step 2), MNV RNA transcripts are generated in vitro using a recombinant T7 RNA polymerase (step 3). The RNA synthesis is confirmed by electrophoresis (step 4) and the template DNA is eliminated using a commercial RNase-free DNase I (step 5). RNA is then purified by an $\mathrm{LiCl}$ precipitation (step 6). The purified RNA product is then capped in vitro (steps 7 ). After purification by LiCl precipitation (step 8), the capped RNA is transfected into either BV-2 cells using Neon transfection system or BSR-T7 cells by lipofection (steps 9). Once inside the cell, capped RNA transcripts will be translated into viral proteins, which should then mediate subsequent rounds of RNA replication to generate VPg-linked RNA that can be packaged to generate infectious virions (steps 10 to 11). To facilitate virus release from cells, one or several cycles of freeze and thaw are performed (step 12). Viral yields can be then determined by $\mathrm{TCID}_{50}$ or plaque assay procedures.

Animal RNA Viruses

\section{K.2.19}

Supplement 33 
A

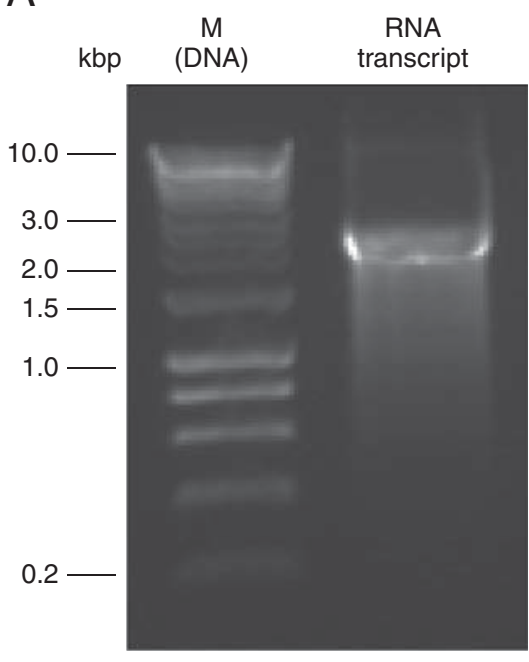

C

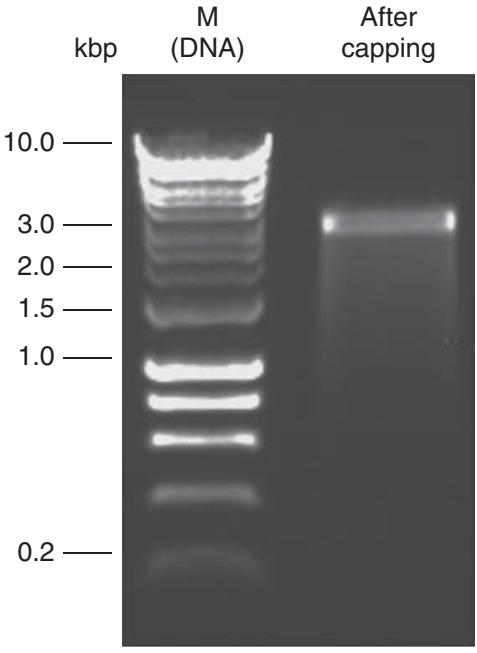

B

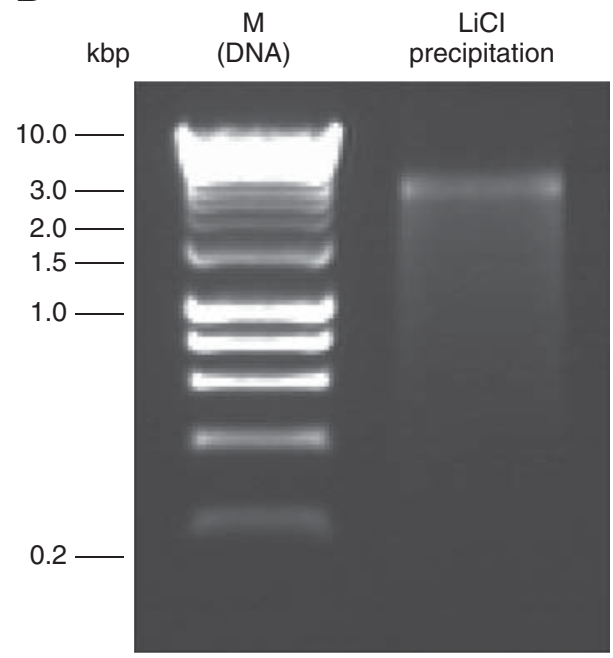

$\mathrm{D}$

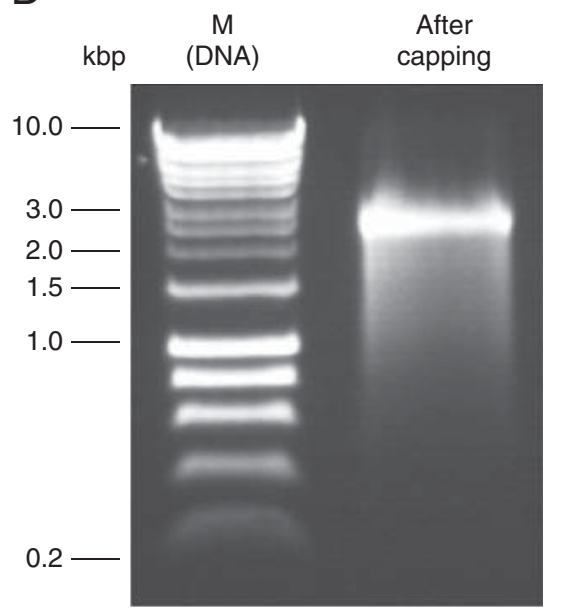

Figure 15K.2.4 Analysis of MNV RNA transcript integrity by nondenaturing gel electrophoresis. (A) Transcription products are run on a nondenaturing $1 \%$ agarose gel in parallel to 1 -kb DNA ladder ( $\mathrm{M}$, lane 1). The relative mobility of viral transcripts under nondenaturing conditions is similar to a dsDNA product of 2.5 to $3 \mathrm{~kb}$. (B) Analysis of RNA transcript after LiCl purification. (C) Analysis of RNA integrity after capping reaction. (D) Analysis of capped-RNA integrity after $\mathrm{LiCl}$ precipitation.

Murine Norovirus: Propagation, Quantification, and Genetic Manipulation

15K.2.20

performed in the same way as for DNA but using RNase-free reagents) to ensure that the reaction has worked efficiently and RNA is full-length.

Denaturing gels provide valuable indications on the size of RNA; however; nondenaturing agarose gel electrophoresis provides a rapid method to analyze RNA integrity. The $M N V$ genome as produced from the infectious cDNA clone $p T 7: M N V 3^{\prime} R z$ will appear as an approximately 3-kbp band relative to a dsDNA ladder on a nondenaturing TBE agarose gel (Fig. 15K.2.4). Alternative methods for the rapid analysis of RNA integrity include the Agilent Bioanalyzer.

The amount of RNA loaded for agarose gel electrophoresis is important for gel resolution; overloading can result in poor resolution. Also, it is essential to ensure that the agarose gel is prepared using RNase-free reagents to avoid RNA degradation during electrophoresis, which may also affect RNA resolution. 
5. Centrifuge the reaction mixture $1 \mathrm{~min}$ at $12,000 \times g, 4^{\circ} \mathrm{C}$, then transfer the supernatant to a new RNase-free microcentrifuge tube. Next, add $2 \mu 1$ DNase I (RNase-free, $2 \mathrm{U} / \mu 1$,), $6 \mu 1 \mathrm{DNase}$ I buffer, and $2 \mu 1$ water. Incubate at $37^{\circ} \mathrm{C}$ for $30 \mathrm{~min}$ before further analysis.

6. Purify the RNA sample to remove the unincorporated nucleotides. For precipitation using $\mathrm{LiCl}$, bring the final volume to $100 \mu \mathrm{l}$ with water and then add $40 \mu \mathrm{l}$ of $\mathrm{LiCl}$ precipitation solution and store the sample at $-20^{\circ} \mathrm{C}$ for 30 min to overnight.

The sample can be stored overnight at this point at $-20^{\circ} \mathrm{C}$, and the purification and in vitro capping continued the following day.

Many other methods are available for removing unincorporated nucleotides, including silica column-based approaches.

7. Pellet the RNA by centrifugation 15 to $30 \mathrm{~min}$ at $12,000 \times g, 4^{\circ} \mathrm{C}$.

8. Remove the supernatant and wash it in $150 \mu \mathrm{l}$ of $70 \%$ ethanol. Centrifuge $15 \mathrm{~min}$ at $12,000 \times g, 4^{\circ} \mathrm{C}$.

Be careful not to disturb the translucent RNA pellet when removing the supernatant.

9. Remove the ethanol and air-dry the RNA.

Avoid drying the pellet for more than $1 \mathrm{~min}$, as a completely dried pellet is difficult to resuspend.

10. Add 50 to $100 \mu \mathrm{l}$ of RNA storage solution to resuspend the MNV transcripts. Remove any insoluble material centrifugation for $5 \mathrm{~min}$ at $12,000 \times \mathrm{g}, 4^{\circ} \mathrm{C}$, prior to RNA quantification.

Care should be taken to ensure that all the RNA has dissolved properly. Heating the sample to $60^{\circ} \mathrm{C}$ may help to resuspend it. The purified transcripts are uncapped and require a subsequent in vitro capping step to be infectious (ScriptCap $m 7 G$ Capping System, Epicentre Biotechnologies; see step 13).

11. Quantify the RNA by spectrophotometry (Gallagher, 2011). Run 100 to $300 \mathrm{ng}$ of sample on a $1 \%$ RNase-free agarose gel (Fig. 15K.2.4D) to check the integrity of RNA before performing the capping reaction.

Depending on the nature and scale of the transcription reaction, typical yields range from 50 to $150 \mu \mathrm{g}$ of RNA per $100 \mu \mathrm{l}$ transcription reaction.

12. To improve the efficiency of RNA capping, heat 60 to $70 \mu \mathrm{g}$ of MNV RNA transcript at $65^{\circ} \mathrm{C}$ for $10 \mathrm{~min}$, and then place the tube immediately on ice. Pulsespin the RNA in a chilled microcentrifuge to collect droplets formed during the heating step at the bottom of the tube.

This step may reduce any inhibitory effect of RNA structure on the capping reaction.

13. Prepare a capping reaction mixture using the ScriptCap m7G Capping System according to the manufacturer's instructions.

Table 15K.2.4 is a typical reaction setup for in vitro capping reaction with a final reaction volume of $100 \mu \mathrm{l}$. However, the reaction volume can be scaled down according to the input amount of RNA and the amount of capped RNA required.

Keep RNA transcripts on ice to avoid degradation. Mix the reaction mixture thoroughly and then incubate at $37^{\circ} \mathrm{C}$ for $1 \mathrm{hr}$. Purify the RNA by LiCl precipitation as described above (see steps 6 to 10). Dissolve the pellet in 50 to $100 \mu \mathrm{l}$ of RNA storage solution and quantify the amount of RNA. It is convenient to adjust the RNA sample concentration to $1 \mu \mathrm{g} / \mu \mathrm{l}$. Again, ensure that all the RNA has dissolved properly and remove any insoluble material prior to RNA quantification by centrifugation. 
Table 15K.2.4 In Vitro Enzymatic Capping Reaction

\begin{tabular}{lll}
\hline Components & Final concentration & Per reaction $(\mu \mathrm{l})$ \\
\hline In vitro transcribed uncapped RNA & $0.6-0.7 \mu \mathrm{g} / \mu \mathrm{l}$ & Varies (total volume less than $73 \mu \mathrm{l})$ \\
$10 \times$ capping buffer & $1 \times$ & 10 \\
$10 \mathrm{mM}$ GTP & $1 \mathrm{mM}$ & 10 \\
$20 \mathrm{mM} S$-adenosyl methionine & $0.1 \mathrm{mM}$ & 0.5 \\
Scriptguard $(40 \mathrm{U} / \mu \mathrm{l})$ & $1 \mathrm{U} / \mu \mathrm{l}$ & 2.5 \\
Scriptcap enzyme $(10 \mathrm{U} / \mu \mathrm{l})$ & $0.4 \mathrm{U} / \mu \mathrm{l}$ & 4 \\
Water & & Varies (to $100 \mu \mathrm{l})$ \\
\hline
\end{tabular}

14. Check the integrity of the capped RNA again before proceeding with the transfection step. To do so, run 100 to $300 \mathrm{ng}$ of sample on a $1 \%$ agarose gel (Fig. 15K.2.4).

The RNA should appear as a single clean band at the correct size without evidence of degradation or smearing and laddering of the RNA (Fig. 15K.2.4D).

For recovery by Neon-mediated transfection of capped RNA into BV-2 cells

For the recovery of MNV infectious virus in a permissive cell line it is possible to electroporate the capped MNV transcripts directly into BV-2 cells using the Neon transfection system (Life Technologies). BV-2 is an immortalized murine microglial cell line that is susceptible to MNV infection, supporting multiple rounds of virus replication and subsequent re-infection (Bocchini et al., 1992; Cox et al., 2009). Yields typically approach $10^{5}$ infectious units per $\mathrm{ml}$ or more at $24 \mathrm{hr}$ post transfection and peak at $>10^{7}$ infectious units per $\mathrm{ml}$ after $48 \mathrm{hr}$, as determined by TCID $_{50}$.

15a. One day before transfection, seed BV-2 cells at an estimated $50 \%$ confluency in BV-2 medium.

Typically a confluent $75-\mathrm{cm}^{2}$ flask (around $8.4 \times 10^{6}$ cells) is sufficient for 1 transfection reaction.

16a. On the day of transfection, aspirate the medium from the cells and detach cells using commercial trypsin (Phelan, 2006).

17a. Neutralize trypsin using BV-2 medium (APPENDIX 4A).

18a. Pellet the cells $5 \mathrm{~min}$ at $1200 \times \mathrm{g}$, room temperature, and resuspend in $10 \mathrm{ml} \mathrm{BV-2}$ medium without antibiotics. Generate a single-cell suspension by repeated pipetting.

19a. Determine the density of live cells using a hemacytometer with trypan blue exclusion (Phelan, 2006).

Each transfection requires $7.2 \times 10^{6}$ cells.

20a. Transfer $7.2 \times 10^{6}$ cells to a sterile $1.5-\mathrm{ml}$ microcentrifuge tube per transfection. Wash the cells with sterile PBS immediately prior to transfection only and pellet $2 \mathrm{~min}$ at $1200 \times g$, room temperature, in a tabletop centrifuge.

21a. Carefully remove all PBS and resuspend cells in $120 \mu \mathrm{l}$ Buffer R (from Neon transfection system) to achieve the desired cell density $\left(6.0 \times 10^{6}\right.$ cells/100 $\left.\mu \mathrm{l}\right)$.

Here, prepare $20 \%$ extra cells and $20 \%$ extra Buffer $R$ to prevent bubble formation while taking cells using the Neon tip. The amount of capped RNA should be scaled accordingly. Cells should not remain in Buffer $R$ for prolonged periods of time due to toxicity; resuspend immediately prior to use. 
22a. Add $1.2 \mu \mathrm{g}$ of capped RNA and mix thoroughly.

23a. Place the electrode of the Neon system inside the hood and place a Neon tube (tip holder) into the electrode. Add $3 \mathrm{ml}$ Solution $\mathrm{E}$ from the kit to the tube.

24a. Label 6-well plates (three wells per sample) and 15-ml conical tubes. Add $9 \mathrm{ml}$ BV-2 medium (without antibiotics) to each conical tube.

Steps $23 a$ and $24 a$ can be done during the centrifugation in step 20a. Each tip holder with Solution E can be used for up to 10 transfections without contamination. However, when trying to recover genetically pure viruses for further studies, it is advisable to replace the tip holder after each transfection.

25a. Mix the cells slowly and take $100 \mu \mathrm{BV}-2$ cells and RNA mixture with the Neon tip using the Neon pipet and insert into the pipet station.

Be careful not to include any bubbles in the cell suspension. The inclusion of bubbles will lead to sparks during the electroporation and cause cell death, which will compromise the transfection rate.

26a. Load the following parameters for optimized BV-2 electroporation (voltage $=1700$ $\mathrm{V}$, width $=10 \mathrm{msec}$, and pulse $=3$ ) and electroporate.

27a. Remove the Neon pipet from the pipet station and transfer the electroporated cells to the $9 \mathrm{ml} \mathrm{BV}-2$ medium in the conical tubes.

28a. Repeat steps $25 \mathrm{a}$ to $27 \mathrm{a}$ for the remaining samples.

29a. Slowly mix transfected BV-2 cells with medium and add $3 \mathrm{ml}$ to each well of labeled 6-well plates.

30a. Incubate the $\mathrm{BV}-2$ cells in a $37^{\circ} \mathrm{C}$ incubator with $5 \%$ to $10 \% \mathrm{CO}_{2}$ until cells adhere ( 4 to $5 \mathrm{hr}$ ), and then replace with medium containing antibiotics.

31a. Incubate the cells in the $37^{\circ} \mathrm{C}, 5 \%$ to $10 \% \mathrm{CO}_{2}$ incubator for 24 to $72 \mathrm{hr}$. Then, release infectious virions from cells by one (or more) freeze and thaw cycles and determine virus titer in the sample using either plaque assay (Alternate Protocol 3) or by TCID $_{50}$ (Basic Protocol 5).

Prior to titration lysates should be clarified by centrifugation for 1 to 2 min at maximum speed. Also, it is optional to pass the lysate through a 0.22- $\mu \mathrm{m}$ filter to exclude any cell debris.

\section{For recovery by transfection into BSR-T7 cells}

15b. One day before transfection, trypsinize a monolayer of BSR-T7 cells (Phelan, 2006) and seed $7.5 \times 10^{5}$ cells into a 35-mm diameter dish (or well of a 6-well plate) in antibiotic-free growth medium and incubate the cells at $37^{\circ} \mathrm{C}$ with $5 \%$ to $10 \% \mathrm{CO}_{2}$ overnight. Double the amount of cells if the transfections are planned for the same day, and allow cells to adhere to the plate for 2 to $3 \mathrm{hr}$ at $37^{\circ} \mathrm{C}$ with $5 \%$ to $10 \%$ $\mathrm{CO}_{2}$.

16b. Remove the medium from the cells and replace with $3 \mathrm{ml}$ of fresh medium without antibiotics to ensure the maximum efficiency of transfection.

17b. Prepare a mixture of $1 \mu \mathrm{g}$ of capped MNV transcript and $100 \mu \mathrm{l}$ of Opti-MEM I and mix it with $4 \mu \mathrm{l}$ of Lipofectamine 2000 pre-mixed in $100 \mu \mathrm{l}$ of Opti-MEM I. Mix the sample thoroughly by pipetting it up and down 15 times. Incubate the mixture at room temperature for $10-15 \mathrm{~min}$.

18b. Re-mix the transfection mixture, and add to the cell monolayer in a dropwise fashion. Gently shake the plate in perpendicular directions. 
19b. Incubate the cells at $37^{\circ} \mathrm{C}$ with $5 \%$ to $10 \% \mathrm{CO}_{2}$ for 24 to $72 \mathrm{hr}$. Afterwards, release infectious virions from cells by freezing and thawing, and determine virus titer by plaque assay (see Alternate Protocol 3) or TCID 50 (see Basic Protocol 5).

BASIC PROTOCOL 5

\section{MEASURING MNV TITERS BY TCID 5}

The tissue culture infectious dose ${ }_{50}\left(\mathrm{TCID}_{50}\right)$ assay is frequently used in virology to determine virus titers. Following serial dilutions, the titer of the virus is calculated based on forming cytopathic effect (CPE) in 50\% of the infected cells after 3 to 5 days of incubation. The procedure involves 10 -fold serial dilutions of each virus sample in a dilution plate, followed by transfer of aliquots of each sample to the test plate containing cells, in quadruplicate. Typically, each sample is assayed as three replicates to ensure reproducibility.

In BV-2 or RAW 264.7 cells, MNV1 is able to achieve high titers of $10^{7}$ or $10^{8}$ following low-MOI (0.01 TCID 50 units/cell) infection and incubation for 24 to $48 \mathrm{hr}$. At that time, cytopathic effect is clear in both cells, with the cells lifting of the bottom of the dish, shrinking in size and becoming apoptotic.

\section{Materials}

Frozen virus supernatant samples for titration (see protocols above)

BV-2 mouse microglial cells (or RAW 264.7 mouse macrophage cells) growing in culture

DMEM-10 medium (see recipe)

96-well tissue culture plates

30- to 300- $\mu 1$ Eppendorf Research Plus multichannel pipettor

10 to $100 \mu \mathrm{l}$ Eppendorf Research Plus multichannel pipettor

$300-\mu 1$ sterile filter pipet tips

1. Take out frozen samples for analysis and thaw them at $37^{\circ} \mathrm{C}$ or room temperature.

For an accurate titer, samples should be prepared in triplicate.

2. Transfer $100 \mu l$ to $1 \mathrm{ml}$ of each sample into a sterile microcentrifuge tube.

3. Centrifuge 3 min at $13,000 \times g$, room temperature, in a benchtop microcentrifuge to pellet cellular debris, and transfer the supernatant to a fresh tube.

4. Add $25 \mu 1$ of each virus supernatant to the first well (row $\mathrm{H}$ ) of the 96-well plate, as shown in Figure 15K.2.5A.

5. Using a 30 to $300 \mu \mathrm{l}$ Eppendorf Research plus manual pipettor, transfer $225 \mu 1$ of medium to all wells in the dilution plate, adding to the wells containing undiluted virus (row H, Fig. 15K.2.5A) last. Pipet samples up and down three times to mix.

6. Eject tips, transfer $25 \mu \mathrm{l}$ from the diluted virus sample to the next row (row G), and mix thoroughly. Repeat this for each subsequent row until the dilution series is complete, ensuring that the tips are changed after each dilution (Fig. 15K.2.5A).

7. Take a $75-\mathrm{cm}^{2}$ flask of BV-2 cells that have reached $75 \%$ to $100 \%$ confluence. Change the medium by adding $10 \mathrm{ml}$ of DMEM-10 medium. Then, scrape the cells and add $9 \mathrm{ml}$ of medium for each $\mathrm{ml}$ of cell suspension-e.g., for $10 \mathrm{ml}$ cell suspension add $90 \mathrm{ml}$ of medium.

RAW 264.7 cells may be substituted for BV-2 cells.

8. Pipet cells up and down to ensure the cells form a single-cell suspension. 
A

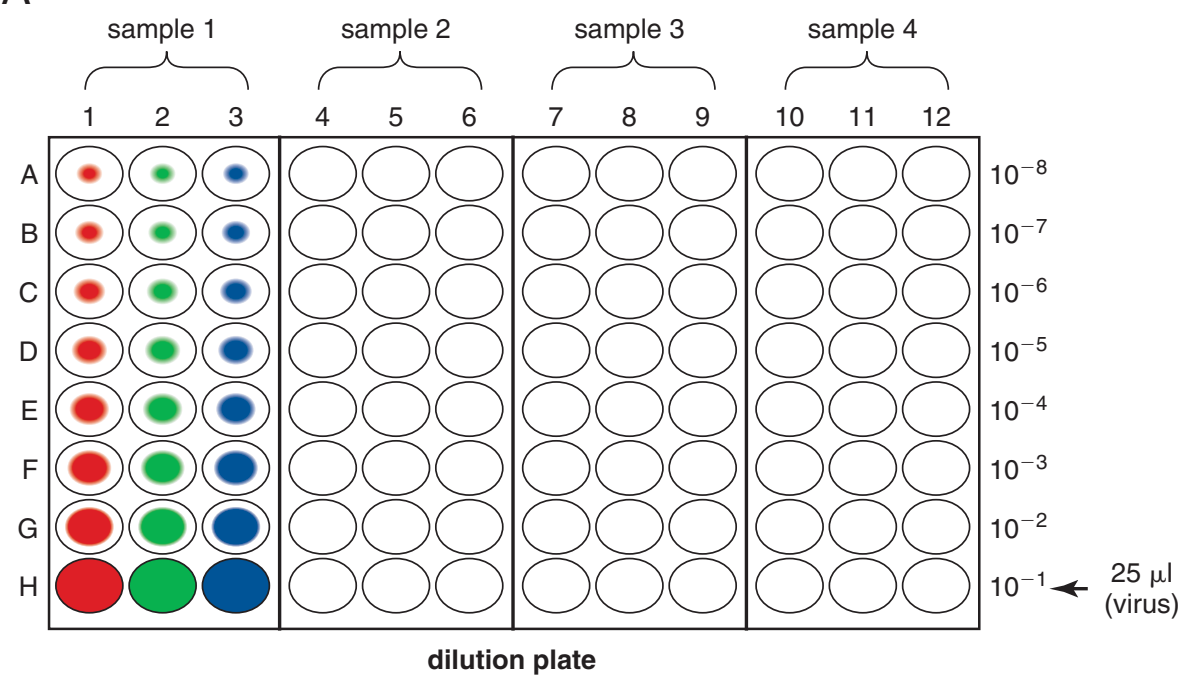

B

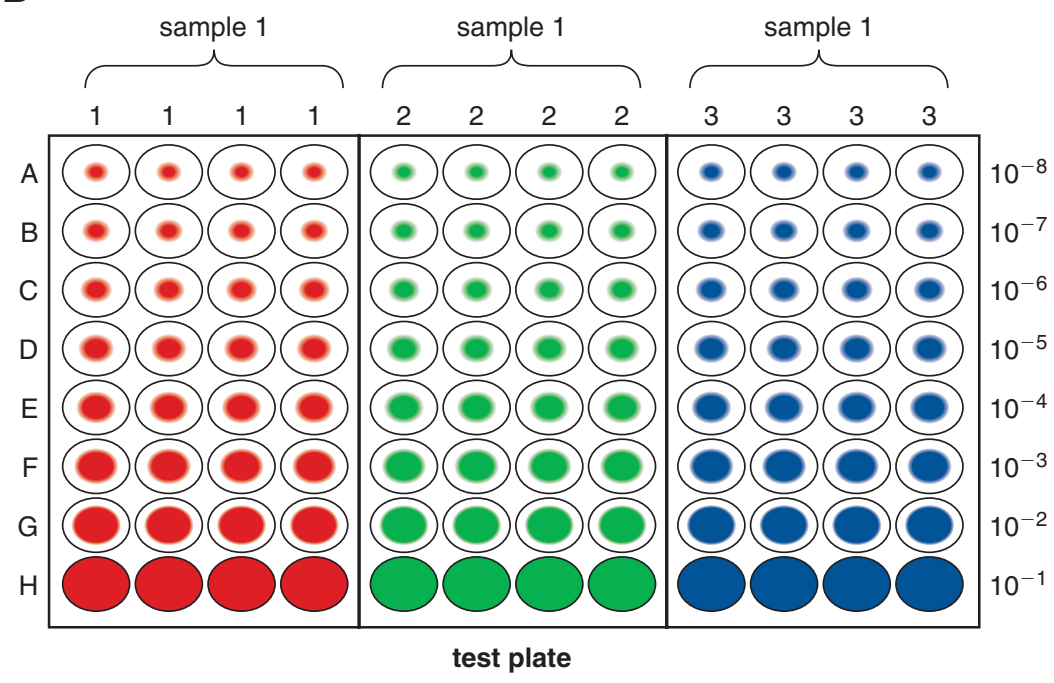

Figure 15K.2.5 Preparation of serial dilutions, and aliquotting of diluted samples. (A) Serial dilutions of the virus are prepared in triplicate from row $\mathrm{H}$ to row $\mathrm{A}$ in the dilution plate. (B) $50 \mu \mathrm{l}$ of each dilution is transferred from the dilution plate to four columns of the test plate.

9. Dispense $100 \mu \mathrm{l}$ of cells into each well of a new, labeled test 96-well plate (test plate) using a multichannel pipettor.

10. Using a multichannel pipettor, transfer $50 \mu \mathrm{l}$ of each dilution from the dilution plate into four columns of the test plate as shown in Figure 15K.2.5B.

11. Incubate at $37^{\circ} \mathrm{C}$ for 3 to 5 days. Check cytopathic effects (CPE) in each well. Score each well in a dish as either infected or uninfected.

In BV-2 cells, CPE is apparent as cells dying and floating off the base of the dish, compared to a confluent monolayer in uninfected cells.

12. Calculate $\operatorname{TCID}_{50}$ values by the Reed \& Muench method (Reed and Muench, 1938; Lindenbach, 2009).

An example and calculation for this method are given in Figure 15K.2.6.

Animal RNA Viruses 
A

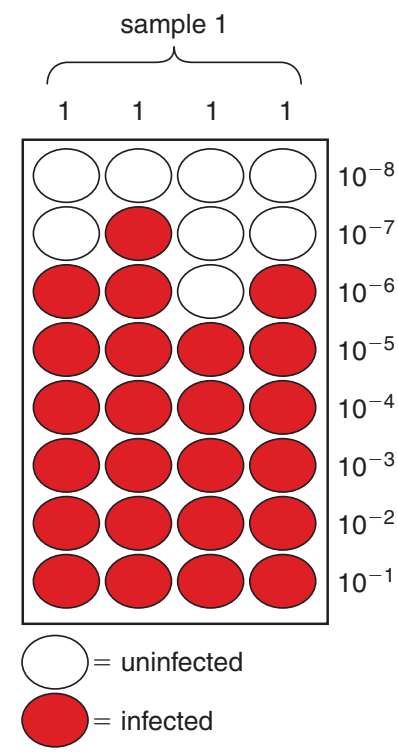

B

Log dilution at or above
$50 \%$ positive
$\downarrow$

C Calculating PD:

$-\mathrm{PD}=\quad \frac{(\% \text { positive at or above } 50 \%-50 \%)}{(\% \text { positive at or above } 50 \%-\% \text { positive below } 50 \%)}$

From this example:

$\mathrm{PD}=(75 \%-50 \%) /(75 \%-25 \%)=-0.5$

D Calculating $\log \mathrm{TCID}_{50}$ :

$\log \operatorname{TCID}_{50}=($ log dilution at or above $50 \%$ positive $)+(-P D)$

From this example:

$\log \operatorname{TCID}_{50}=(-6)+-0.5=-6.5$

E

Calculating $\mathrm{TCID}_{50} / \mathrm{ml}$

$\mathrm{TCID}_{50} / \mathrm{ml}=\left(1 / 10^{\log \mathrm{TCID}_{50}}\right) /$ dilution factor

From this example:

$\mathrm{TCID}_{50} / \mathrm{ml}=\left(1 / 10^{-6.5}\right) / 0.5=6.32 \times 10^{7} \mathrm{TCID}_{50} / \mathrm{ml}$

Figure 15K.2.6 Manual calculation of $\mathrm{TCID}_{50} / \mathrm{ml}$ values. (A) An example $\mathrm{TCI}_{50}$ result, also given in table format in (B). (C) Calculation of the proportionate distance (-PD). (D) Using -PD to calculate $\log T C I D_{50}$. Calculation of $\mathrm{TCID}_{50} / \mathrm{ml}$ from the $\log \mathrm{TCID}_{50}$ and dilution factor.

The dilution at which 50\% of the wells are infected is calculated using the following equation:

( $\%$ positive at or above $50 \%$ ) $-50 \%$

Murine

Norovirus:

Propagation, Quantification,

and Genetic

Manipulation
15K.2.26 
$(\log$ dilution at or above $50 \%)+(-P D)=\log T_{C I D}$

This $\log$ TCID $_{50}$ value is then used to express the virus titer as TCID 50 /unit volume, e.g., $\mathrm{TCID}_{50} / \mathrm{ml}$.

$T_{C I D} / \mathrm{ml}=\left(1 / 10^{\log T C I D 50}\right) /$ dilution factor

In this method, $50 \mu$ l of virus is added to each well, so the dilution factor is 0.05 .

For simplicity, an Excel spreadsheet created by Dr. Brett D. Lindenbach may be used for the calculation (Lindenbach, 2009). This spreadsheet is available from http://www.lindenbachlab .org/resources.html

\section{MEASURING MNV TITERS BY PLAQUE ASSAY}

The plaque assay is used to measure infectious virions in a given sample. It is based on the published protocol by Gonzalez-Hernandez et al. (2012), and is an alternative method to the $\mathrm{TCID}_{50}$ assay. Compared to $\mathrm{TCID}_{50}$, the plaque assay is shorter by 1 to 3 days. In the procedure, dilutions of a virus stock are incubated with cell monolayers, overlaid with agarose, and stained with neutral red to visualize plaques after 2 days. A video of the plaque assay can be found at $h t t p: / / w w w . j o v e . c o m / v i d e o / 4297 / p l a q u e-a s s a y-f o r-m u r i n e-$ norovirus.

\section{Materials}

RAW 264.7 cells (ATCC no. TIB-71)

DMEM-10 (see recipe)

$3 \%(\mathrm{w} / \mathrm{v})$ SeaPlaque agarose (see recipe), prewarmed

Complete $2 \times$ MEM medium (see recipe)

Virus supernatant samples for titration (see protocols above)

0.33\% Neutral Red solution (Sigma, cat no. N2889)

Phosphate-buffered saline (PBS), pH 7.4, sterile (e.g., Life Technologies, cat. no.10010-023)

6- and 24- or 48-well plates

Repeater pipettor

Multichannel pipettor

Single channel pipettor

Filtered pipet tips

Rocker

1. Plate cells at $2 \times 10^{6}$ cells per well of a 6-well plate in $2 \mathrm{ml}$ DMEM-10 (i.e., $1 \times$ $10^{6}$ cells $\left./ \mathrm{ml}\right)$. Incubate cells overnight at $37^{\circ} \mathrm{C}$ in $5 \% \mathrm{CO}_{2}$.

2. Label plates and organize them based on the samples you will be testing.

A suggestion for an efficient biosafety hood setup is shown in Figure 15K.2.7.

3. Add medium to 24- or 48-well plate for the number of dilutions that you are using and label them (for -1 dilutions in duplicate add $1.35 \mathrm{ml}$ of medium to each well, and for -2 dilution add $1.5 \mathrm{ml}$ of medium per well).

Use 50-ml attachment for repeater pipet for plating cells and for adding medium to dilution plates. For the 50-ml repeater pipet to fit, the cell suspension and medium need to be in a 250-ml Stericup flask.

4. Prewarm complete $2 \times$ MEM medium at $37^{\circ} \mathrm{C}$ and heat $3 \%$ Seaplaque in microwave, and then leave in $57^{\circ} \mathrm{C}$ water bath until ready to use.

5. Make virus dilutions by adding $150 \mu \mathrm{l}$ of virus to -1 dilutions for a total of $1.5 \mathrm{ml}$, and add $15 \mu \mathrm{l}$ to -2 dilutions for a total of $1.515 \mathrm{ml}$.

6. Aspirate off medium from 6-well plates. 


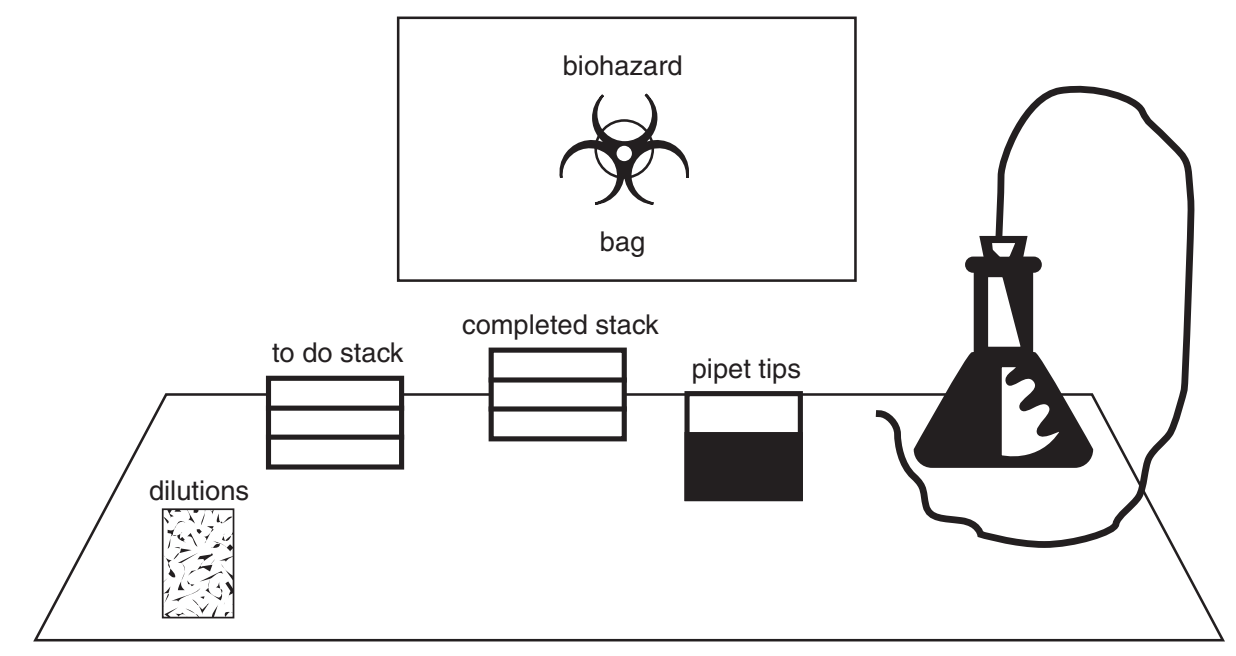

Figure 15K.2.7 Schematic of the biosafety hood setup. Efficient organization of the biosafety hood minimizes spills and increases speed of the assay without compromising precision.

7. Add $500 \mu \mathrm{l}$ of a given dilution to two wells each for duplicate wells.

8. Rock for $1 \mathrm{hr}$ at room temperature.

9. Mix prewarmed $\left(37^{\circ} \mathrm{C}\right) 2 \times$ MEM and warm $\left(37^{\circ}\right.$ to $\left.42^{\circ} \mathrm{C}\right) 3 \%(w / v)$ Seaplaque agarose together in 1:1 ratio (add medium first and then add Seaplaque from the $57^{\circ} \mathrm{C}$ water bath so that it cools off).

The Seaplaque/2×MEM solution should be prepared immediately before use.

10. Aspirate off virus and add $2 \mathrm{ml}$ of SeaPlaque/ $2 \times$ MEM to each well.

11. Incubate at $37^{\circ} \mathrm{C}$ for $48 \mathrm{hr}$.

\section{Overlay for plaque assay}

12. Mix $3 \mathrm{ml}$ of Neutral Red with $100 \mathrm{ml}$ PBS. Equilibrate to $37^{\circ} \mathrm{C}$ before use.

13. Overlay $2 \mathrm{ml}$ of neutral red/PBS mixture per well.

Add the neutral red using the 50-ml repeater pipet.

14. Incubate at $37^{\circ} \mathrm{C}$ for 1 to $2 \mathrm{hr}$.

15. Aspirate off neutral red/PBS mixture.

16. Count plaques and calculate titer.

When performing each dilution in duplicate (i.e., $1 \mathrm{ml}$ of a given dilution is analyzed), add together the number of plaques from each of the two wells times the dilution factor to equal the titer.

ALTERNATE PROTOCOL 4

Murine Norovirus: Propagation, Quantification, and Genetic Manipulation

15K.2.28

\section{MEASURING MNV GENOME TITERS BY RT-qPCR}

The determination of MNV levels can be achieved through amplification of viral nucleic acid (RNA) by reverse transcription quantitative polymerase chain reaction (RT-qPCR). This technique produces high enough concentrations of nucleic acid for detection and quantification by fluorescence. In general, this technique relies on purification of viral RNA, an initial synthesis of cDNA (complementary or copy DNA) by the enzyme reverse transcriptase using virus-specific primers, and subsequent exponential amplification of 
that cDNA coupled to real-time detection of amplification levels via readouts of fluorescence. Reverse transcription can be performed as either a single reaction for cDNA synthesis or coupled to qPCR.

In this protocol, we discuss a one-step RT-qPCR reaction for MNV-1 amplification modified from previously published work (Taube et al., 2009), providing a reliable determination of viral RNA levels. The conditions mentioned in this protocol were optimized for use in the BioRad CFX96 Touch qPCR instrument, and provide analytical sensitivity, analytical specificity, reproducibility, and repeatability, thus making them suitable for publication following MIQE guidelines (Bustin et al., 2009). It is advised that conditions be optimized for alternative instruments, as variations in results from instrument to instrument can occur (technical replicate examination). If RNA quality is optimal, and no DNA contamination is present, efficient amplification of MNV-1 from a variety of starting materials (e.g., stool, tissue) is achieved.

\section{Materials}

$10 \%$ bleach solution

$70 \%$ ethanol

RNase Away reagent (Life Technologies/Ambion, cat. no. 10328-011)

Viral RNA extraction kit (e.g., Qiagen QiaAmp Viral RNA Kit, cat. no. 52906),

RNA extraction kit (e.g., Qiagen RNeasy Mini kit, cat. no. 74104), or

Trizol reagent (Life Technologies, cat. no. 15596026)

Nuclease-free $\mathrm{H}_{2} \mathrm{O}$ (APPENDIX $2 A$ or purchase, e.g., from Invitrogen)

Ambion Turbo DNA-free DNase (Life Technologies, cat. no. AM1907) and Turbo DNA-free buffer

Ambion Turbo DNA-free DNase Inactivation Reagent

Amplification kit: BioRad iScript One-step RT-PCR kit for Probe (cat. no. 170-88940) or BioRad iTaq Universal Probes One-Step kit (cat. no. 172-5140)

Primers: both primers bind in ORF1 of the MNV-1 genome.

Forward primer $\left(5^{\prime} \rightarrow 3^{\prime}\right)$ : GTGCGCAACACAGAGAAACG (HPLC purified)

Reverse primer $\left(5^{\prime} \rightarrow 3^{\prime}\right)$ : CGGGCTGAGCTTCCTGC (HPLC purified)

Probe $\left(5^{\prime} \rightarrow 3^{\prime}\right)$ : [6-FAM]-CTAGTGTCTCCTTTGGAGCACCTA-[BHQ1] (HPLC purified): probe is modified at the $5^{\prime}$-end with a fluorescein amidite molecule (FAM), and at the 3'-end with the non-fluorescent molecule Black Hole Quencher 1 (BHQ1)

Unknown sample RNAs

Plasmid containing the MNV-1 genome (for standard preparation)

Microcentrifuges (one designated for RNA work and one for DNA/plasmid work) 96-well PCR plates (Hard-Shell PCR plates 96-well white shell/clear well; BioRad, cat. no. HSP9601)

Optical film (Microseal 'B' seal, BioRad, cat. no. MSB1001)

Two sets of pipettors (one for RNA handling and one for plasmid handling)

Nuclease-free 1.5-ml tubes

BioRad CFX96Touch qPCR machine

\section{Viral RNA extraction}

1. Prepare the area for RNA extraction by thoroughly cleaning it once with a $10 \%$ bleach solution, followed by spraying it with $70 \%$ ethanol, and lastly by wiping it twice with RNase Away.

This will help remove and/or minimize the presence of ribonucleases and DNA contamination in the area. 
Also wipe your gloved hands with RNase Away often, and change gloves every time you touch surfaces that have not been cleaned. This step is crucial for obtaining high-quality RNA, which is needed for successful downstream applications. Use of an "RNA-workonly" designated area is advisable.

2. Carefully wipe the RNA-extraction pipettors with RNase Away. Make sure to also pipet a full volume of RNase Away into the pipettors, without a tip, so that it can decontaminate any potential RNases and DNA inside the pipettor barrel.

RNA-extraction pipettors should be soaked overnight in RNase Away periodically. DO NOT use RNase Away on gaskets, seals, aluminum, or soft metals.

3. Extract viral RNA from virus-containing samples (e.g., virus-containing lysates or homogenized tissues) using an appropriate method according to the manufacturer's protocol.

If using the QIAamp Viral RNA Kit, be sure to use the "spin column method" with an "RNA-only" microcentrifuge. A vacuum manifold may be used only if one is sure that the device has not been utilized to isolate plasmid DNA, as cross-over contamination can occur. If cellular RNA (from virus-infected cells) is to be extracted, use of the RNeasy Mini kit from Qiagen has provided great RNA yields and quality. If isolating RNA via the Trizol method, make sure to perform an RNA cleanup using silica membrane-based columns, to remove any phenol contaminants.

4. Perform an RNA cleanup step, in case any plasmid or DNA contamination (however minimal) has occurred in the elution step. Do this using Ambion Turbo DNA-free DNase as follows:

a. After the elution of the RNA, add sufficient amount of $10 \times$ Turbo DNA-free buffer for a final $1 \times$ concentration in a volume containing $1 \mu l$ of Turbo DNase.

b. Incubate this solution at $37^{\circ} \mathrm{C}$ for 25 to $30 \mathrm{~min}$.

c. Add Ambion Turbo DNA-free DNase Inactivation Reagent (same volume you add of $10 \times$ buffer plus enzyme and water), and vortex several times to keep it dispersed in solution.

d. Incubate for $5 \mathrm{~min}$ at room temperature.

e. Centrifuge at full speed to pellet inactivation reagent.

f. Pipet up almost the whole volume of sample you had originally (make sure to pipet up about $5 \mu 1$ less than what you had originally) to avoid carryover of the inactivation reagent.

IMPORTANT NOTE: Inactivation reagent WILL inhibit your qPCR reactions.

g. Proceed with RT-qPCR.

This step is performed because of the use of plasmid DNA containing the MNV-1 amplicon as a potential source of contamination. Cleanup could alternatively be performed as an "on-column" DNase treatment, but this protocol has not been proven successful in completely removing contaminating DNA.

5. To ensure RNA stability and integrity, prepare aliquots and freeze at $-80^{\circ} \mathrm{C}$.

Addition of RNase inhibitors is also a way of ensuring RNA stability. However, if using the commercially available kits or reagents mentioned in this protocol, and maintaining an RNase-free environment by using and "RNA-only" work zone/gloves and cleaning with RNase Away, RNases are inactivated due to highly denaturing conditions and should not affect your extraction significantly. Also, not all commercially available RNase inhibitors are compatible with RT-qPCR. For this protocol, it is not necessary to add an RNase inhibitor, but the reader might do so as long as it is verified that subsequent amplifications by RT-qPCR are efficient.

If the RNA is isolated from infected cells, you can measure its quantity and estimate its purity/integrity via spectrophotometry, making sure you measure absorbance at 260 and $280 \mathrm{~nm}$ and obtain a 260/280 ratio with a value of 1.9 to 2.0. If the RNA is 
Table 15K.2.5 Master Mix for RT-qPCR ${ }^{a}$

\begin{tabular}{llll}
\hline Component & Initial concentration & Volume/reaction $(1 \times$ final $)$ & Master mix (96-well) $\times 96$ samples \\
\hline $2 \times$ master mix & $2 \times$ & $10 \mu \mathrm{l}$ & $980 \mu \mathrm{l}$ \\
Forward primer & $10 \mu \mathrm{M}$ & $0.1 \mu \mathrm{l}$ & $9.8 \mu 1$ \\
Reverse primer & $10 \mu \mathrm{M}$ & $0.1 \mu \mathrm{l}$ & $9.8 \mu 1$ \\
Probe & $10 \mu \mathrm{M}$ & $0.25 \mu \mathrm{l}$ & $24.5 \mu 1$ \\
RT & $50 \times$ & $0.4 \mu \mathrm{l}$ & $39.2 \mu 1$ \\
Nuclease-free $\mathrm{H}_{2} \mathrm{O}$ & - & $4.15 \mu \mathrm{l}$ & $406.7 \mu 1$ \\
Template & - & $5 \mu 1$ & - \\
Total & - & $20 \mu 1$ & $1470 \mu 1$ \\
\hline
\end{tabular}

${ }^{a}$ The volumes and components outlined here are found in the BioRad iScript OneStep RT-PCR kit for Probe.

isolated from cell-free material with the use of a kit and carrier RNA (e.g., Qiagen kits), spectrophotometric readings will only be useful for determining 260/280 ratios, as the amount of carrier RNA will in most cases exceed the amount of viral RNA present, and does not provide a very accurate measurement of viral RNA concentration.

\section{Performing RT-qPCR}

This reaction was optimized for the BioRad CFX96Touch qPCR machine using the primer matrix and temperature gradient methods to provide the optimal conditions for the highest primer and probe combinations. It results in the highest efficiency reaction with both optimal $\mathrm{Cq}$ and fluorescence intensity.

6. Plan the plate arrangement according to the number of samples to be assayed, always including the standards, a no-template control, a positive control, and a no-RT control as part of the sample group.

Each sample should be run in duplicate, but preferably in triplicate, to observe for pipetting error.

7. Thaw reaction components on ice, mix them thoroughly, and briefly centrifuge them to collect the volume at the bottom of the tubes.

Light-sensitive components (e.g., probe) should be protected from light.

8. Set up the RT-qPCR reaction by calculating the amount of reagents needed. Reaction volume should be $20 \mu \mathrm{l}$ final.

If another volume is made, concentration of both primers should be $0.05 \mu M$ final and probe concentration should be $0.125 \mu \mathrm{M}$ final.

All steps may be performed at room temperature if a vendor-supplied mix is used, as most reaction mixes contain a hot-start Taq polymerase and reagents that are stable at room temperature for several hours. However, reactions can be assembled on ice when degradation is suspected.

Plates may be made several days in advance and stored at $4{ }^{\circ} \mathrm{C}$ until the reactions are ready to run. This does not cause a substantial decline in the performance of the PCR enzyme. Advance preparation of plates is not recommended if qPCR mixes are not from commercial sources (i.e., they are home-made), as these mixes lack additives present in the commercial mixes that confer stability to the reaction components. Whenever possible, fresh reactions should be run.

9. Prepare a master mix in a $1.5 \mathrm{ml}$ nuclease-free tube (see Table 15K.2.5), containing each reagent but no template, for at least 1.5 to 2 samples more than what you have to run (i.e., make an excess of master mix).

Animal RNA Viruses

15K.2.31 
10. Mix thoroughly to ensure homogeneity and dispense $15-\mu 1$ aliquots into the required wells of a 96-well plate. Use good pipetting technique to ensure precision and accuracy.

11. Dispense $5 \mu l$ of each unknown sample RNA into the required well, using RNA-only pipettors.

The no-template control should have master mix and nuclease-free water. For the no-RT control, do not add RT enzyme, and make up the volume with nuclease-free water.

Use equal volume for samples isolated from cell-free materials. For infected cell RNA, measure RNA concentration (Gallagher, 2011) and load equal amounts of RNA, preferably in equal volume.

Dispense the standards last, after performing at least six 10-fold serial dilutions of the plasmids (step 13).

It is generally not advisable to use DNA as a standard for absolute quantification of RNA because there is no control for the efficiency of the reverse-transcription step. However, if it is not possible to in vitro transcribe RNA, the use of plasmid DNA with the template of interest is fine. Be sure to linearize the plasmid prior to amplification, as super-coiled DNA is not as efficiently amplified as linear DNA (template site is not as accessible to primers if DNA is super-coiled).

12. Make serial dilutions of standards.

To make serial dilutions of your standards, you first have to know the molar concentration of your plasmid. This way you can calculate copy numbers to be translated into genome copies later on.

a. Determine the concentration of the linearized plasmid by spectrophotometry and convert the readout to $g$ per liter.

b. Calculate the formula weight $(\mathrm{FW})$ for your plasmid as follows: Plasmid size (in base pairs) $\times 662$ grams $/ \mathrm{mol}$ (average weight of a nucleotide pair).

c. Calculate the molar concentration of your linearized plasmid (M): $\mathrm{M}=\mathrm{mol} / \mathrm{liter}=($ mass in $\mathrm{g} / \mathrm{FW}) / 1$ liter

d. Determine copy number per microliter based on molar concentration:

$1 \mathrm{M}$ is about $6.02 \times 10^{23}$ copies.

13. Make 10-fold serial dilutions of the plasmid in nuclease-free water and add $5 \mu 1$ to the dispensed reaction mix. Make note of how many copies of plasmid each sample standard contains.

Pipetting accuracy is crucial in this step for correct analyses of samples after the PCR run.

14. Cover the plate with the optical adhesive cover and then briefly centrifuge the plate to get contents to the bottoms of the wells, and to remove any air bubbles.

15. Load the plate into the instrument and run the RT-qPCR reaction using the following thermal cycler program:

$\begin{array}{llll}1 \text { cycle: } & 10 \mathrm{~min} & 50^{\circ} \mathrm{C} & \text { (reverse transcription) } \\ 1 \text { cycle: } & 5 \mathrm{~min} & 95^{\circ} \mathrm{C} & \text { (initial denaturation) } \\ 40 \text { cycles: } & 10 \mathrm{sec} & 94^{\circ} \mathrm{C} & \text { (denaturation) } \\ & 30 \mathrm{sec} & 60^{\circ} \mathrm{C} & \text { (annealing). }\end{array}$

16. Perform data analysis according to the instrument-specific instructions. 

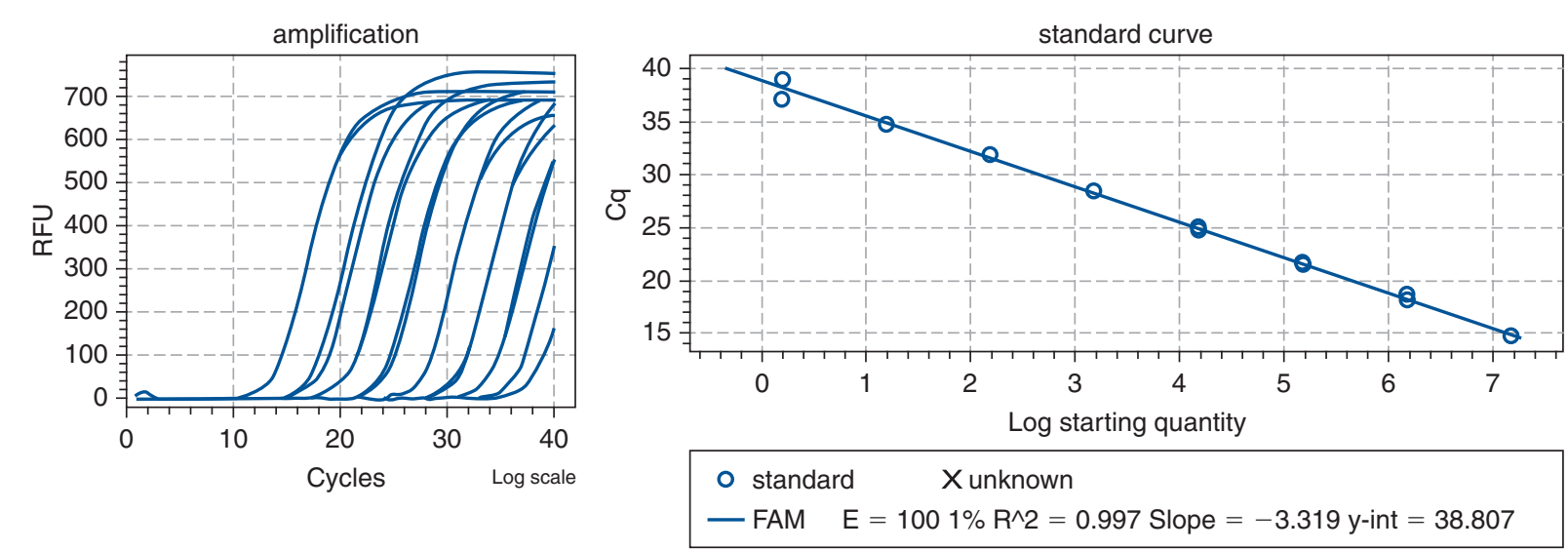

Figure 15K.2.8 RT-qPCR results for standard curve amplification of a plasmid containing the MNV-1 ORF1 region. Eight 10-fold serial dilutions were made of a plasmid containing the MNV-1 ORF1 region and were run as duplicates in an RT-qPCR experiment with BioRad reagents and the BioRad CFX96 Touch instrument. (A) Amplification plot of MNV-1 standards. (B) Automatic standard curve generated by the BioRad CFX96 Touch instrument. Note that the slope of the curve has a value of -3.319 , which corresponds to the approximate $100.1 \%$ amplification efficiency of the primers binding to its target template and allows for an exact doubling of nucleic acid quantities with each cycle of amplification.

Make sure that your standard curve has a correlation coefficient $\left(R^{2}\right)$ higher than 0.98 and shows a slope close to -3.3, which ensures that your primers have close to $100 \%$ efficiency for amplification (you have double the original amount of template as each cycle progresses). Figure 15K.2.8 shows an example of a standard curve obtained for $M N V-1$ standards. The most dilute standard within the linear range of the standard curve is 2 genome copies (Fig. 15K.2.8B). Thus, the reliable limit of detection for this particular protocol of MNV-1 amplification is 2 genome copies.

17. To calculate the genome copies per $\mathrm{ml}$ of virus in your preparation, multiply the genome copies per well calculated in your RT-qPCR run by the dilution factor obtained after the RNA extraction experiment and according to the sample volume loaded in the reaction.

\section{STRAND-SPECIFIC QUANTIFICATION OF MNV-1 RNA}

The presence of negative-strand viral RNA during any positive-strand RNA virus infection is an indicator of active replication. The specific detection and quantification of the (-) strand viral RNA is therefore an important tool for the study of molecular mechanism of viral RNA replication. However, due to the fact that both most reverse transcriptase enzymes produce "self-primed" and "false-primed" cDNA, and the presence of both $(+)$ and (-) strand during virus replication, absolute quantification of either strand is not possible by regular RT-qPCR. Several modifications can overcome these problemsincluding a thermo-stable reverse transcriptase and use of a non-viral tag sequence in the reverse transcription primer, which is then used for specific amplification of tagged cDNA - and make the assay strand-specific (Timofeeva and Skrypina, 2001; Piche and Schernthaner, 2003; Stahlberg et al., 2004; Tuiskunen et al., 2010). The protocol described herein is based on a recently published method that utilizes these modifications for the detection and absolute quantification of MNV-1 positive and negative strand (Vashist et al., 2012a,b). The Basic Protocol describes all the steps of strand-specific RT-qPCR (RNA-primer annealing, reverse transcription, and qPCR). During reverse transcription, a strand-specific oligonucleotide primer containing sequence complementary to the strand being detected is annealed with the RNA, and cDNA is synthesized using reverse transcriptase. This cDNA is then enzymatically amplified by SYBR-based
BASIC PROTOCOL 6

Animal RNA Viruses

\section{K.2.33}

Supplement 33 
Table 15K.2.6 Primers Used for RT-qPCR

\begin{tabular}{lllll}
\hline RNA & & Name & Sequence 5'-3' $^{\prime}$ & Position $^{a}$ \\
\hline Gpos & RT & TposGpos & CGGGAAGGCGACTGGAGTGCCCAAACATCTTTCCCTTGTTC & 1760-1779 \\
& qPCR - F & Tpos & CGGGAAGGCGACTGGAGTGCC & Nonviral \\
& qPCR $-\mathrm{R}$ & Gneg & TGGACAACGTGGTGAAGGAT & $1678-1697$ \\
Gneg & RT & TnegGneg & GGCCGTCATGGTGGCGAATAATGGACAACGTGGTGAAGGAT & $1678-1697$ \\
& qPCR - F & Tneg & GGCCGTCATGGTGGCGAATAA & Nonviral \\
& qPCR -R & Gpos & CAAACATCTTTCCCTTGTTC & $1760-1779$ \\
\hline
\end{tabular}

${ }^{a}$ The genome positions are with reference to the MNV-1.CW-1 genome RNA sequence. The standard RNAs were designed to include the neighboring RNA secondary structure complexity to imitate the actual RNA.

${ }^{b}$ The $5^{\prime}$ end of the forward primer (underlined sequence) is T7 promoter. T7 polymerase needs this sequence to start RNA synthesis.

qPCR, and the absolute number of RNA copies is determined by extrapolation from a standard curve. The standard curve-plotting function is available in most instrument software. If it is not, graphing software may be used instead (e.g., Microsoft Excel or GraphPad Prism). This qPCR protocol can reproducibly detect down to 50 copies per well.

\section{Materials}

Total RNA isolated from infected cells (see "Viral RNA extraction" steps in Alternate Protocol 4)

Control in vitro-transcribed RNA (Support Protocol 4)

$10 \mu \mathrm{M}$ RT primer (Table 15K.2.6)

$10 \mathrm{mM}$ dNTP mix (APPENDIX 2A)

$5 \times$ first-strand synthesis buffer (Life Technologies, supplied with SuperScript III)

M DTT (Life Technologies, supplied with SuperScript III)

$40 \mathrm{U} / \mu 1$ RNaseOUT (Life Technologies)

SuperScript III (SS-III) reverse transcriptase (Life Technologies, cat. no. 18080-044) and 5× RT buffer

Nuclease-free $\mathrm{H}_{2} \mathrm{O}$ (APPENDIX $2 A$; or purchase, e.g., from Life Technologies)

$10 \mu \mathrm{M}$ PCR primers (Table 15K.2.6)

$2 \times$ MESA Blue Mastermix (Mesa Blue qPCR Mastermix for SYBR Assay, Eurogentec)

PCR tubes

Heat block

96-well qPCR plates

qPCR thermal cycler (Life Technologies)

Thermosealer (Life Technologies)

\section{Anneal the primer to the RNA}

1. In a PCR tube, mix the strand-specific RT primer-TposGpos, for positive-sense RNA or TnegGneg for negative-sense RNA - total RNA, and dNTP mix by adding the following to a microcentrifuge tube:

100 ng total RNA or serially diluted control standard (in vitro-transcribed) RNA

$0.2 \mu 110 \mu \mathrm{M}$ RT primer

$1 \mu 110 \mathrm{mM}$ dNTP mix

$\mathrm{H}_{2} \mathrm{O}$ to $11 \mu 1$. 
2. Heat to $65^{\circ} \mathrm{C}$ and snap freeze on ice.

Heating the mix removes any secondary structures in the RNA and allows the primer to begin to anneal.

\section{cDNA synthesis}

3. Microcentrifuge the sample for $10 \mathrm{sec}$ at $1000 \times g$ to collect the condensate at the bottom of the tube.

4. Add $9 \mu 1$ of RT mix per reaction, prepared as follows:

$4 \mu 15 \times$ first-strand synthesis buffer

$1 \mu l 0.1 \mathrm{mM}$ DTT

$0.8 \mu 1$ RNaseOUT

$0.2 \mu 1$ SuperScript III reverse transcriptase

Nuclease-free $\mathrm{H}_{2} \mathrm{O}$ to $9 \mu \mathrm{l}$.

A master mix can be prepared for more than one reaction and kept on ice. When using this approach, it is advisable to include at least an extra $10 \%$ to $15 \%$ in the final volume of the master mix to allow for pipetting errors. Once prepared, master mix should be kept on ice.

5. Mix the contents of PCR tubes and incubate for $30 \mathrm{~min}$ at $55^{\circ} \mathrm{C}$.

6. Inactivate the RT enzyme by heating the PCR tubes to $95^{\circ} \mathrm{C}$ for $5 \mathrm{~min}$.

7. Centrifuge the sample for $10 \mathrm{sec}$ at $1000 \times g$ to collect the condensate at the bottom of the tube.

SuperScript III RT is a thermostable enzyme and has high processivity at $55^{\circ} \mathrm{C}$. Use of a thermostable enzyme as well as a calibrated amount of $R T$ primer and time of reaction allows minimum synthesis of false-primed cDNA.

It is important to centrifuge the tubes after heating to recover evaporated solution to accurately determine the RNA quantity.

\section{Amplify the cDNA by qPCR and analyze data}

8. Mix the following:

For $(+)$ strand RNA detection

$0.25 \mu$ l each qPCR primer (Tpos and Gneg-Table 15K.2.6)

$10 \mu 12 \times$ MESA Blue Mastermix

Nuclease-free water to $18 \mu 1$.

For (-) strand RNA detection

$0.25 \mu 1$ each qPCR primer (Tneg and Gpos-Table 15K.2.6)

$10 \mu 12 \times$ MESA Blue Mastermix

Nuclease-free water to $18 \mu 1$.

Use of the tag primer gives specificity to the PCR reaction. Hence, any false-primed $c D N A$ without the tagged $R T$ primer would not be amplified during the PCR reaction.

For each reaction, a master mix can be prepared for more than one reaction and kept on ice. When using this approach, it is advisable to include at least an extra $10 \%$ to $15 \%$ in the final volume of the master mix to allow for pipetting errors. Once prepared, master mix should be kept on ice.

9. Transfer $18 \mu 1$ of the PCR mix from the above step to wells of a 96-well qPCR plate.

10. Add $2 \mu 1 \mathrm{cDNA}$ standards (step 7; from RNA representing $2 \times 10^{7}$ to 20 copies/well) to respective wells. 


\begin{tabular}{|c|c|c|c|c|c|c|c|c|c|c|c|c|}
\hline & 1 & 2 & 3 & 4 & 5 & 6 & 7 & 8 & 9 & 10 & 11 & 12 \\
\hline A & $0 \mathrm{Hr}$ & $0 \mathrm{Hr}$ & $0 \mathrm{Hr}$ & 2.E+07 & 2.E+07 & 2.E +07 & $0 \mathrm{Hr}$ & $0 \mathrm{Hr}$ & $0 \mathrm{Hr}$ & 2.E+07 & 2.E+07 & 2.E+07 \\
\hline $\mathrm{B}$ & $6 \mathrm{Hr}$ & $6 \mathrm{Hr}$ & $6 \mathrm{Hr}$ & 2.E +06 & 2.E +06 & 2.E +06 & $6 \mathrm{Hr}$ & $6 \mathrm{Hr}$ & $6 \mathrm{Hr}$ & 2. $E+06$ & 2.E+06 & $2 . E+06$ \\
\hline $\mathrm{C}$ & $12 \mathrm{Hr}$ & $12 \mathrm{Hr}$ & $12 \mathrm{Hr}$ & 2.E +05 & 2.E +05 & 2.E+05 & $12 \mathrm{Hr}$ & $12 \mathrm{Hr}$ & $12 \mathrm{Hr}$ & 2.E+05 & $2 . E+05$ & $2 . E+05$ \\
\hline $\mathrm{D}$ & $24 \mathrm{Hr}$ & $24 \mathrm{Hr}$ & $24 \mathrm{Hr}$ & 2.E +04 & 2.E +04 & 2.E+04 & $24 \mathrm{Hr}$ & $24 \mathrm{Hr}$ & $24 \mathrm{Hr}$ & 2. $E+04$ & 2.E+04 & $2 . E+04$ \\
\hline$E$ & & & & $2 . E+03$ & $2 . E+03$ & 2.E+03 & & & & $2 . E+03$ & $2 . E+03$ & $2 . E+03$ \\
\hline $\mathrm{F}$ & & & & 200 & 200 & 200 & & & & 200 & 200 & 200 \\
\hline $\mathrm{G}$ & & & & 20 & 20 & 20 & & & & 20 & 20 & 20 \\
\hline $\mathrm{H}$ & & & & NTC & NTC & NTC & & & & NTC & NTC & NTC \\
\hline & \multicolumn{6}{|c|}{ positive sense } & \multicolumn{6}{|c|}{ negative sense } \\
\hline
\end{tabular}

Figure 15K.2.9 A typical layout of the qPCR plate is shown. Rows 1 to 6 contain master mix for detection of positivesense RNA and Rows 7 to 12 contains master mix for negative-sense RNA. Rows 1 to 3 and 4 to 6 contain samples from mentioned time points of growth curve while rows 4 to 6 and 10 to 12 contain samples for standard curve and no-template control.

It is important to dilute the standard RNA in the presence of a carrier RNA. We typically use $20 \mathrm{ng} / \mu \mathrm{l}$ yeast $R N A$.

11. Add $2 \mu 1$ cDNA samples (step 7) to respective wells.

12. Seal the plate with a thermosealer, making sure that all the wells are sealed, particularly the corners of the plate.

13. Place the plate in the plate holder of the qPCR machine.

14. Perform qPCR using the following thermal cycling parameters.

Data collection for the detection of PCR amplification is performed during the annealing and extension steps of the PCR cycle, while for the melt curve stage the data is collected at the ramp stage between annealing and dissociation.

a. PCR program:

$\begin{array}{rlll}1 \text { cycle: } & 10 \mathrm{~min} & 95^{\circ} \mathrm{C} & \text { (activates the polymerase) } \\ 50 \text { cycles: } & 15 \mathrm{sec} & 95^{\circ} \mathrm{C} & \text { (denaturation) } \\ & 20 \mathrm{sec} & 58^{\circ} \mathrm{C} & \text { (annealing) } \\ & 20 \mathrm{sec} & 72^{\circ} \mathrm{C} & \text { (extension). }\end{array}$

b. Melting curve analysis:

$\begin{array}{ll}15 \mathrm{sec} & 95^{\circ} \mathrm{C} \\ 20 \mathrm{sec} & 58^{\circ} \mathrm{C}\end{array}$

Increase from $58^{\circ}$ to $95^{\circ} \mathrm{C}$ at a $0.05^{\circ} \mathrm{C} /$ in temperature ramping rate

$20 \mathrm{sec} \quad 95^{\circ} \mathrm{C}$.

A typical layout of the plate for a growth curve using time points $0 \mathrm{hr}, 6 \mathrm{hr}, 12 \mathrm{hr}$, and $24 \mathrm{hr}$, including standard curve and no template control, is presented in Figure 15K.2.9.

15. Analyze the qPCR data by extrapolating from the standard curve.

The standard curve plotting function is available on most software provided with qPCR machines. If such software is not provided, graphing software may be used instead by plotting Ct Values versus $\log _{10}$ copy number of the control standard RNA.

Norovirus:

Propagation,

Quantification,

and Genetic

Manipulation

15K.2.36

It is very important to analyze the melting curve before analyzing the amplification data. The melting point $\left(T_{m}\right)$ of all the PCR products should be identical. If the $T_{m}$ deviates, it is indicative of either primer-dimer formation or the generation of nonspecific PCR products. Such wells should be excluded from the analysis of amplification data. 
Table 15K.2.7 Primers Used for Generation of Standard RNAs

\begin{tabular}{llll}
\hline Standard RNA & Name & Sequence 5'-3'a $^{\prime a}$ & Position $^{b}$ \\
\hline Gpos $^{7}$ & Gpos-F & GCGTAATACGACTCACTATAGGGCTTTTGGCCTCACCTCTG & $1085-1104$ \\
& Gpos-R & CCAAGATGAAATTGATGTGGCTGTAATCGGGCC & $1954-1986$ \\
Gneg $^{7}$ & Gneg-F & GCGTAATACGACTCACTATAGGGTGCCAAGATGAAATTGATG & $1970-1990$ \\
& Gneg-R & GCTTTTGGCCTCACCTCTG & $1086-1104$ \\
\hline
\end{tabular}

${ }^{a}$ The $5^{\prime}$ end of the forward primer (underlined sequence) is T7 promoter. T7 polymerase needs this sequence to start RNA synthesis.

${ }^{b}$ The genome positions are with reference to the MNV-1.CW-1 genome RNA sequence. The standard RNAs were designed to include the neighboring RNA secondary structure complexity to imitate the actual RNA.

\section{GENERATION OF STANDARD RNAS REPRESENTING MNV-1 (+) AND (-) SENSE GENOMIC RNAS}

For the absolute quantification of RNA copies in a sample, it is important to make a standard curve using a known number of copies of control standard RNA representing the amplified region. This protocol describes a method for the preparation of RNA standards representing the positive and negative strands of the MNV-1 genomic RNA. The use of RNA instead of DNA for the generation of a standard curve also allows for control at the RT step. The control standard RNA can be synthesized by in vitro transcription reaction as described below. Several commercially available in vitro transcription kits could also be used to prepare the RNA.

\section{Materials}

$100 \mathrm{ng} / \mu 1$ plasmid DNA template (pT7:MNV1 3'Rz, available without MTA from

Dr. Ian Goodfellow, Cambridge University)

KOD polymerase kit (Merck)

$10 \mathrm{mM}$ dNTP mix (APPENDIX 2A)

$10 \mu \mathrm{M}$ PCR primers (Table 15K.2.7)

$1 \%$ agarose TBE gel (Voytas, 2000)

$0.5 \times$ TBE buffer (APPENDIX 2A)

DNA ladder (e.g., GeneRuler 1-kb Plus, Fermentas)

PCR purification kit (GE Healthcare)

$0.4 \mathrm{M}$ Tris $\cdot \mathrm{Cl}, \mathrm{pH} 8.0$ (APPENDIX 2A)

$320 \mathrm{mM}$ magnesium acetate

$400 \mathrm{mM}$ DTT

$20 \mathrm{mM}$ spermidine

$100 \mathrm{mM}$ ATP

$100 \mathrm{mM}$ GTP

$100 \mathrm{mM}$ CTP

$100 \mathrm{mM}$ UTP

Pyrophosphatase (New England Biolabs, cat. no. M2403L)

40 U/ $\mu 1$ RNaseOUT (Life Technologies)

Nuclease-free water

T7 RNA polymerase (Promega, cat. no. P2074)

Nuclease-free $\mathrm{H}_{2} \mathrm{O}$ (APPENDIX 2A, or purchase, e.g., from Promega or NEB)

$2 \mathrm{U} / \mu 1$ DNase I (RNase-free, Life Technologies)

$3 \mathrm{M}$ sodium acetate, $\mathrm{pH} 5.2$ (APPENDIX 2A)

25:24:1 (v/v/v) phenol/chloroform/isoamyl alcohol

$100 \%(\mathrm{v} / \mathrm{v})$ ethanol

$75 \%$ (v/v) ethanol

Nanodrop spectrophotometer (http://www.nanodrop.com)
SUPPORT

PROTOCOL 4
Animal RNA

Viruses

15K.2.37 
Additional reagents and equipment for agarose gel electrophoresis (Voytas, 2000) and SDS-PAGE (APPENDIX 3M)

\section{Generate PCR product with $T 7$ promoter at the $5^{\prime}$ end}

1. Generate Gpositive and Gnegative PCR products using the KOD polymerase kit according to the manufacturer's instructions along with pT7:MNV1 $3^{\prime} \mathrm{Rz}$ as template and PCR primers detailed in Table 15K.2.7.

pT7:MNV1 3'Rz is the full length infectious clone of MNV-1.CW-1 (Chaudhry et al., 2007).

2. Run the PCR product on a $1 \%$ agarose gel (Voytas, 2000) in TBE buffer along with a DNA ladder and purify the DNA using a commercially available gel purification kit.

\section{Generate RNA using in vitro transcription}

3. Mix the following in the order as described below:

It is important to maintain the order of addition of the components in this reaction and to mix well after adding each component. A master mix lacking the template DNA can be prepared, and then aliquotted to facilitate the synthesis of several transcripts at once. Keep all reagents on ice once thawed. A commercially available kit (e.g., Promega, P1440) could also be used for in vitro transcription.

$10 \mu 10.4$ M Tris $\cdot \mathrm{Cl}, \mathrm{pH} 8.0$

$10 \mu 1320 \mathrm{mM}$ magnesium acetate

$10 \mu \mathrm{l} 400 \mathrm{mM}$ DTT

$10 \mu 120 \mathrm{mM}$ spermidine

$7.5 \mu 1100 \mathrm{mM}$ ATP

$7.5 \mu 1100 \mathrm{mM}$ GTP

$7.5 \mu 1100 \mathrm{mM}$ CTP

$7.5 \mu 1100$ mM UTP

$2 \mu l$ pyrophosphatase

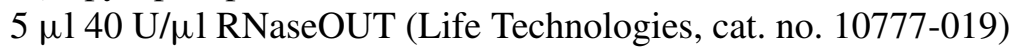

$10 \mu \mathrm{l}$ PCR product from step 2 (>200 ng)

$10 \mu 1$ T7 RNA polymerase (Promega, cat. no. P2074)

Nuclease-free $\mathrm{H}_{2} \mathrm{O}$ to $100 \mu$ l.

4. Mix well and incubate 2 to $4 \mathrm{hr}$ at $37^{\circ} \mathrm{C}$.

5. Run $2 \mu 1$ on denaturing 5\% SDS-PAGE gel (BioRad Mini Protean gel or similar) to check the yield and purity of the RNA (APPENDIX $3 M$ ).

6. Add $2 \mu 1$ of $2 \mathrm{U} / \mu 1 \mathrm{DNase}$ I and continue the incubation in $37^{\circ} \mathrm{C}$ water bath for another $30 \mathrm{~min}$.

7. Add $100 \mu 1$ nuclease-free water.

8. Add $20 \mu 10.3 \mathrm{M}$ sodium acetate to each sample and mix well.

9. Extract each sample with $200 \mu 1$ of 25:24:1 phenol/chloroform/isoamyl alcohol. Carefully transfer only the aqueous phase from each tube to a new $1.5-\mathrm{ml}$ microcentrifuge tube.

CAUTION: Phenol is a neurotoxin. Local safety regulations for its use and disposal should be followed.

10. Add $500 \mu \mathrm{l}$ of $100 \%$ ethanol and mix well. Microcentrifuge each sample $15 \mathrm{~min}$ at $13,000 \times g, 4^{\circ} \mathrm{C}$, to collect the RNA in the pellet. 
11. Carefully remove the liquid from the small white pellets and add $400 \mu \mathrm{l}$ of $75 \%$ ethanol to each tube. Centrifuge $5 \mathrm{~min}$ at $13,000 \times g$.

12. Carefully remove all the liquid from the pellets. Dry the pellets at room temperature and dissolve each in $100 \mu l$ nuclease-free water.

Excessive drying will prevent the RNA from dissolving in water.

13. Quantitate the RNA using a Nanodrop UV spectrophotometer.

14. Convert RNA concentration to copy number.

Tools and scientific calculators are widely available to do this calculation (see Internet Resources). To calculate manually:

a. Calculate the concentration of RNA using the formula: $1 A_{260}=40 \mu \mathrm{g} / \mathrm{ml}$.

b. Calculate the molecular weight of the RNA molecule using the formula: mol. wt. $=$ (no. of nucleotides $\times 320.5)+159$.

320.5 is the average molecular weight of the nucleotides and 159 is the molecular weight of a $5^{\prime}$ triphosphate.

c. Calculate copy number using the formula: Copy number/ $\mu \mathrm{l}=6.02 \times 10^{23} \times[R N A]$ in $\mu \mathrm{g} / \mathrm{ml} \times 10^{-9} /(\mathrm{mol}$. wt. in $\mathrm{g} / \mathrm{mol})$.

15. Aliquot and store the samples at $-80^{\circ} \mathrm{C}$ at $10^{10} \mathrm{copies} / \mu 1$.

\section{SIRNA TRANSFECTION OF BV-2 CELLS USING NEON TRANSFECTION SYSTEM}

Understanding of the role of host-cell genes during MNV infection is facilitated by manipulating these genes in tissue culture. siRNAs designed against specific genes are a powerful tool that can be delivered into cells to down-regulate expression of their target mRNA. Transfecting nucleic acid into cells can be achieved by a variety of mechanisms, including chemical, mechanical, and electrical delivery. Electroporation of nucleic acid into cells was first proposed in 1982 (Neumann et al., 1982), and has since developed into a highly efficient research tool. To overcome the initial problems of low cell viability, low transfection rates, and complicated protocols, Kim et al. (2008) produced a novel electroporation system using a capillary and wire-type electrode. This was initially developed as the Microporator (MP-100) by Digital Bio. This has since been optimized, and is now marketed by Life Technologies as the Neon transfection system. In cell culture, MNV infects cells of the macrophage lineage, such as BV-2 cells (murine microglial cell line) and RAW 264.7 cells (murine leukemic monocyte macrophage cell line). siRNA transfection of BV-2 cells via the Neon transfection system (Life Technologies) is efficient and has been successfully used to study the role of target host genes during MNV infection (Vashist et al., 2012a,b). This protocol describes the methods used to transfect large numbers of cells with a specific siRNA, often resulting in significant reduction in the target protein within $18 \mathrm{hr}$ of transfection. However, it is recommended to analyze target gene expression at various time points between 12 and $48 \mathrm{hr}$ post transfection to determine the optimum time for maximal reduction in gene expression.

\section{Materials}

Confluent flask(s) of BV-2 cells (Blasi et al., 1990), passaged $24 \mathrm{hr}$ prior to start of protocol to ensure actively growing cells

Phosphate-buffered saline (PBS), pH 7.4, sterile (e.g., Life Technologies, cat. no.10010-023)

BV-2 medium: Dulbecco's Modified Eagle Medium (DMEM) supplemented with $10 \%$ fetal bovine serum (FBS), $2 \mathrm{mM}$ L-glutamine, and $1 \times$ penicillin/streptomycin (omit antibiotics where instructed), $37^{\circ} \mathrm{C}$

Animal RNA Viruses 
siRNAs: directed against the target and a control housekeeping gene (e.g., GAPDH) NEON $100 \mu l$ kit; (Life Technologies, cat. no. MPK10096; (contains Buffers E and $\mathrm{R}$, gold tips, and tip holder)

NEON pipet (Life Technologies, cat. no. MPP100)

6-well cell culture dishes

15-ml sterile conical tubes (e.g., BD Falcon)

Additional reagents and equipment for basic cell culture techniques including trypsinization and cell counting (Phelan, 2006), and western blotting (Gallagher et al., 2008)

1. Aspirate the medium from the BV-2 cells, wash the monolayer with PBS, and detach the cells using commercial trypsin (all techniques described in Phelan, 2006).

A total of $7.2 \times 10^{6}$ live cells will be required per transfection.

2. Neutralize trypsin using prewarmed BV-2 medium, then remove the suspended cells from the culture flask and centrifuge in a tabletop centrifuge $5 \mathrm{~min}$ at $1200 \times \mathrm{g}$, room temperature. Remove the supernatant and resuspend the cells in $10 \mathrm{ml}$ of BV-2 medium.

3. Determine the concentration of live cells in presence of trypan blue (Phelan, 2006).

4. Transfer $7.2 \times 10^{6}$ live cells to a sterile microcentrifuge tube for each transfection. Centrifuge cells $2 \mathrm{~min}$ at $1200 \times \mathrm{g}$, room temperature, in a tabletop centrifuge, remove supernatant, then resuspend in $1 \mathrm{ml}$ PBS.

It is advisable to leave cells in growth medium until immediately before washing with $P B S$. Typically, cells can be aliquotted into sterile microcentrifuge tubes and kept at room temperature until required. The time period that cells are exposed to PBS and Buffer $R$ (see step 8) should be kept to an absolute minimum.

5. Place the electrode of the Neon system inside the tissue culture hood where the transfection is to take place and place a Neon tube (tip holder) in the electrode. Add $3 \mathrm{ml}$ Buffer $\mathrm{E}$ to this Neon tube.

Each Neon tube with Buffer $E$ can be used for up to 10 transfections without contamination.

6. Set the instrument parameters for the following conditions: voltage, 1700; width, $10 \mathrm{msec}$; pulse, 3 .

7. Label 6-well plates ( 3 wells per sample) and $15-\mathrm{ml}$ conical tubes. Add $9 \mathrm{ml} \mathrm{BV-2}$ medium (without antibiotics) to each conical tube.

8. Centrifuge the $7.2 \times 10^{6}$ cells suspended in PBS (from step 4) 2 min at $1200 \times g$, room temperature, in tabletop centrifuge. Remove the supernatant, then resuspend the cells in $120 \mu \mathrm{l}$ Buffer $\mathrm{R}$ to achieve the desired cell concentration of $6.6 \times 10^{6}$ cells/100 $\mu 1$ for each transfection.

It is advisable to use $20 \%$ extra cells in $20 \%$ extra Buffer $R$ as described above to avoid bubble formation during aspiration of cells by the Neon tip. The amount of siRNA should thus be altered accordingly.

9. Add the required amount of target siRNA to $7.2 \times 10^{6}$ cells in Buffer R, mixing carefully and thoroughly.

$5 \mu \mathrm{l}$ of a $10 \mu \mathrm{M}$ stock of siRNA $(0.5 \mu \mathrm{mol})$ is recommended as a starting concentration. 


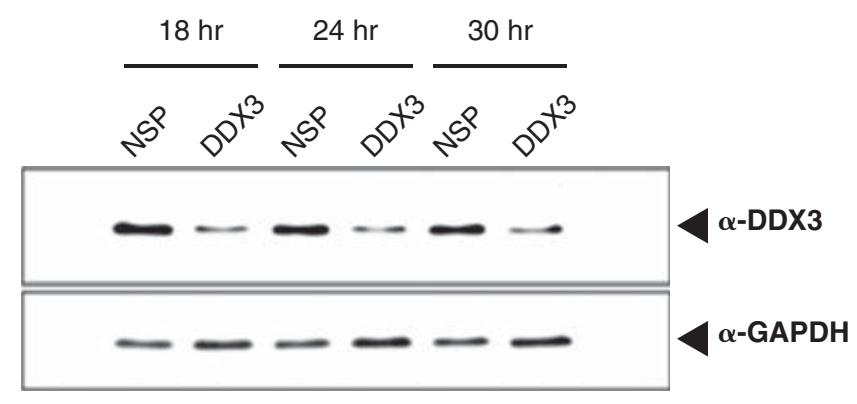

Figure 15K.2.10 siRNA-mediated reduction in protein expression as demonstrated by western blotting. siRNA targeting the host cell gene DDX3 and control siRNA were transfected into BV-2 using the Neon transfection system. Cells were harvested at 18-, 24-, and 30-hr time points, and protein extracted. Protein samples were then separated using SDS-PAGE and analyzed using western blotting with anti-DDX3 and anti-GAPDH as loading controls.

10. Mix the cells slowly and gently, then aspirate $100 \mu \mathrm{l}$ of the cell-siRNA mix into the Neon tip using the Neon pipet. Insert this into the pipet station until a click is heard.

IMPORTANT NOTE: It is essential to avoid any air bubble formation while setting up the sample for electroporation. Formation of bubbles during mounting of the electrode is common, and the process must be carefully repeated until no bubbles are present. Air bubbles result in the generation of sparks during electroporation, and hence major cell death.

11. Press the start button to start electroporation.

The machine will confirm successful electroporation once completed.

12. Remove the Neon pipet from the pipet station and transfer the electroporated cells to the $9 \mathrm{ml}$ of medium in the conical tube (pre-prepared in step 7).

13. Repeat steps 8 to 12 for the remaining samples.

NOTE: Each Neon tip can be reused up to a maximum of three times for transfection of cell samples with the same type of siRNA.

14. Mix the electroporated cells slowly with the fresh medium and add $3 \mathrm{ml}$ each to 3 wells of labeled 6-well culture dishes.

15. Incubate at $37^{\circ} \mathrm{C}$ with $5 \% \mathrm{CO}_{2}$ until the cells form a monolayer (this can take between 6 and $18 \mathrm{hr}$ ). When a monolayer is formed, replace the medium with BV-2 cell medium containing antibiotics.

16. Harvest cells at predetermined time-points (between 12 and $48 \mathrm{hr}$ are suggested), and analyze protein expression of the target gene using western blotting (Fig. 15K.2.10).

Protocols for western blotting (immunoblotting) are provided in Gallagher et al. (2008).

\section{LENTIVIRAL TRANSDUCTION OF PRIMARY BONE MARROW-DERIVED MACROPHAGES FOR MNV INFECTION}

Analysis of viral replication in primary cells is an efficient way to study the interaction of virus with its host in more physiological conditions than in transformed or immortalized cell lines. However, compared to established cell lines, it is difficult to obtain a homogenous population of primary cells in sufficient number for experimentation. It is also difficult to modify the phenotype of primary cells due to the low efficiency of

BASIC PROTOCOL 8

Animal RNA Viruses

15K.2.41 
transfection. Bone marrow-derived macrophages obtained through culturing bone marrow progenitor cells with macrophage colony-stimulating factor (M-CSF) (Stanley et al., 1983) is a good solution for securing a large number of primary cells for MNV infection; transduction of these cells with lentivirus is an efficient way to over-express or downregulate a gene of interest. In this protocol, bone marrow cells are harvested and cultured in medium containing M-CSF to generate bone marrow-derived macrophages (Support Protocol 5), and lentiviruses are produced in $293 \mathrm{~T}$ cells by transfecting lentiviral vector with packaging and pseudotyping vectors (Support Protocol 6). Prepared lentiviruses are used to transduce adherent cells from the bone marrow progenitors twice, on Days 4 and 5 of culture. On Day 7, transduced bone marrow-derived macrophages are harvested for further selection or subsequent assays. This procedure optimally yields 5-10 $\times 10^{6}$ macrophages, of which $>90 \%$ express the gene of interest or the cassette for down-regulating the gene of interest.

\section{Materials}

Day 4 bone marrow culture for the derivation of macrophages (Support Protocol 5) Macrophage complete medium (see recipe)

Lentiviral vectors (Support Protocol 6)

Selection antibiotic, e.g., $1 \mu \mathrm{g} / \mathrm{ml}$ puromycin in culture medium

PBS/EDTA solution (e.g., Sigma, cat. no. E8008)

10 -cm culture plates

Sterile cell lifter (e.g., Fisher Scientific, cat. no. 08100 240)

50-ml conical tubes (e.g., BD Falcon)

6- or 24-well culture plates

Additional reagents and equipment for basic cell culture techniques including trypsinization and cell counting (Phelan, 2006)

1. On Day 4 of bone marrow culture (Support Protocol 5), gently swirl the plate a couple of times to detach any loosely bound materials and remove the unbound with culture medium.

Typically, 50\% to 60\% confluency is expected on Day 4.

2. Add $5 \mathrm{ml}$ of fresh macrophage complete medium and half of the prepared lentivirus (i.e., $\sim 10 \mathrm{ml}$ ) per $10-\mathrm{cm}$ plate.

Replacing macrophage complete medium help cells stay healthy.

Addition of polybrene does not enhance the transduction of vesicular stomatitis virus $G$ protein $(V S V-G)$ pseudotyped lentiviral vectors.

3. On Day 5, discard the culture medium with lentivirus and add $5 \mathrm{ml}$ of fresh macrophage complete medium and the rest of the prepared lentivirus (i.e., $\sim 10 \mathrm{ml}$ ) per 10 -cm plate.

4. Optional: Select transduced cells by expression of reporter gene (e.g., green fluorescent protein from pCDH-MCS-T2A-copGFP-MSCV) or drug resistance gene (e.g., puromycin $\mathrm{N}$-acetyltransferase from pLKO.1 puro). For the drug selection of transduced cells, add drug (e.g., $1 \mu \mathrm{g} / \mathrm{ml}$ puromycin) for 3 days, on Days 6 through 9.

5. On Day 7 (or on Day 9 for drug-selected cells), remove unbound cells and discard culture medium. Add $5 \mathrm{ml}$ of cold PBS to the remaining adherent cells, swirl gently to remove loosely bound cell debris, discard the PBS, and add $5 \mathrm{ml}$ of cold PBS/EDTA per each plate. Incubate at $4^{\circ} \mathrm{C}$ for $10 \mathrm{~min}$.

For transduced but unselected cells, a confluency of $90 \%$ to $100 \%$ is expected, while $70 \%$ to $80 \%$ confluency is expected for the transduced and drug-selected cells. 
6. Scrape off the cells with cell lifter, add $5 \mathrm{ml}$ of cold macrophage complete medium per plate, resuspend the cells by pipetting up and down, and transfer them to a 50-ml conical tube.

Keep macrophages cold to minimize loss due to their adherence to the tube.

7. Centrifuge $5 \mathrm{~min}$ at $300 \times g, 4^{\circ} \mathrm{C}$.

8. Discard supernatant, resuspend the cells in 5 to $10 \mathrm{ml}$ macrophage complete medium, and count the number of cells (Phelan, 2006).

The volume of the resuspension medium needs to be determined based on subsequent assays. The typical yield at this stage is $5-10 \times 10^{6}$ transduced macrophages for the unselected and 1-3 $\times 10^{6}$ transduced macrophages for the drug-selected cells per 10-cm plate.

9. At this time, replate macrophages for further experimentation.

Usually, the cells are plated at $0.5-1 \times 10^{5}$ cells/well in $1 \mathrm{ml}$ of macrophage complete medium for a 24-well tissue culture plate or at $2.5-5 \times 10^{5}$ cells/well in 2 ml of macrophage complete medium for a 6 -well tissue culture plate.

Three days after seeding, macrophages are ready to be used for MNV infection (for example as described in Basic Protocol 1) and subsequent assays (e.g., western blot or quantitative PCR to measure the over-expression or down-regulation of genes of interest).

The efficiency of transduction and/or expression of gene of interest in the transduced cells can vary significantly depending on the size of the lentiviral vector. In general, the efficiency inversely correlates with the size of the lentivirus. For example, over $90 \%$ of cells expressed green fluorescent protein upon transduction with lentiviruses from $\mathrm{pCDH}$ MCS-T2A-copGFP-MSCV vector itself, but only $20 \%$ to $30 \%$ of cells showed the reporter expression upon transduction with lentiviruses having an additional $\sim 2-k b p$ gene (Hwang et al., 2012).

\section{PREPARATION OF MOUSE BONE MARROW SUSPENSION FOR MACROPHAGE CULTURE}

This protocol describes the purification of bone marrow progenitor cells from mouse hind legs (both tibias and femurs) and differentiation into bone marrow-derived macrophages with medium containing M-CSF.

NOTE: All protocols involving live animals must be reviewed and approved by an Institutional Animal Care and Use Committee (IACUC) and must conform to government regulations for the care and use of laboratory animals.

\section{Materials}

Donor mice, 6- to 12-weeks old, specific pathogen-free

$70 \%$ ethanol

Phosphate-buffered saline (PBS), pH 7.4, sterile (e.g., Life Technologies, cat. no.10010-023)

Macrophage complete medium (see recipe)

Forceps and scissors (keep in sterile container containing 70\% ethanol)

$100 \times 15-\mathrm{mm}$ petri dishes (non-tissue culture treated)

15 - and 50-ml conical centrifuge tube, sterile

10 - or 30-ml syringes with $26-\mathrm{G}$ needles, sterile

Additional reagents and equipment for mouse euthanasia (APPENDIX $3 N$ )

1. Euthanize a mouse according to the guidelines of the home institution (e.g., $\mathrm{CO}_{2}$ asphyxiation then cervical dislocation; see APPENDIX $3 N$ ). Briefly sterilize the 
euthanized mouse either by spraying sufficient $70 \%$ ethanol to cover the whole body or by soaking the mouse in $70 \%$ ethanol. Cut out the foot, peel off skin, and cut off the hind legs at the hip joint, keeping the tibias and femurs intact.

Dissection in clean environment (e.g., inside biosafety cabinet) is recommended to minimize any contamination.

2. Remove excess muscle from tibias and femurs, briefly dip them in the $70 \%$ ethanol in a Petri dish for quick sterilization, and put them in a new clean petri dish.

3. Remove the mouse carcass, clean up the biosafety cabinet, and get a new pair of gloves and sterile equipment if necessary.

If the dissection equipment is going to be used again, make sure to clean and sterilize with $70 \%$ ethanol.

4. Prepare one 50-ml conical tube per mouse and fill up the tube with macrophage complete medium. Load a syringe with the prepared macrophage complete medium in the tube and attach a $26-\mathrm{G}$ needle.

Alternatively, you can start with wash medium or PBS to collect bone marrow first, spin down at $300 \times g$ for $5 \mathrm{~min}$, discard supernatant, and resuspend the cell pellet in the macrophage complete medium.

5. Using sterile forceps and scissors, cut both ends of bones proximal to each joint and insert needle into bone marrow cavity. Flush bone cavity with medium until color of bone cavity changes from red to white.

It takes usually 2 to $3 \mathrm{ml}$ of medium to completely flush out bone marrow from one bone.

6. Combine the bone marrows from a single mouse in a 50-ml conical tube.

7. Mix well by pipetting up and down and plate the cells into non-tissue culture treated $100 \times 15-\mathrm{mm}$ petri dishes. Usually, dispense $10 \mathrm{ml}$ of bone marrow suspension per petri dish and make up to 10 petri dishes per mouse.

Macrophages do not come off tissue culture-treated plasticware. Make sure to use non-tissue culture treated petri dishes to enable replating of bone marrow-derived macrophages.

Each petri dish of cells is transduced with a single type of lentivirus, so the number of petri dishes of cells should match the number of lentiviruses for transduction.

Typically, bone marrow progenitor cells from a single mouse can be plated in up to 10 petri dishes to produce similar number of bone marrow-derived macrophages per dish at the time of harvest (i.e., on Day 7).

8. Incubate the cells in $37^{\circ} \mathrm{C}, 5 \% \mathrm{CO}_{2}$ incubator for 4 days.

All culture incubations should be performed in a humidified, $37^{\circ} \mathrm{C}, 5 \% \mathrm{CO}_{2}$ incubator unless otherwise specified.

SUPPORT PROTOCOL 6

\section{Murine Norovirus: Propagation, Quantification, and Genetic Manipulation}

15K.2.44

\section{PRODUCTION OF LENTIVIRAL VECTOR}

This protocol describes the preparation of VSV-G pseudotyped lentiviruses through the transfection of relevant plasmids into 293T cells. VSV-G is a highly stable protein with ubiquitously expressed receptors on mammalian cells, so it enhances the structural stability and tropism of the pseudotyped lentivirus.

\section{Materials}

293T cells (ATCC no. CRL-3216)

DMEM-10 medium (see recipe) 
Plasmids:

Pseudotyping vector encoding the $\mathrm{G}$ protein of vesicular stomatitis virus

(VSV-G, e.g., pMD2.G, Addgene plasmid 12259)

Lentiviral packaging vector (e.g., psPAX2, Addgene plasmid 12260)

Lentiviral vector of choice (e.g., pCDH-MCS-T2A-copGFP-MSCV, System

Biosciences CD523A-1, for the over-expression of a gene or pLKO.1

puro, Addgene plasmid 8453, for the down-regulation of a gene)

$2.5 \mathrm{M} \mathrm{CaCl}_{2}$, sterile

$2 \times \mathrm{HeBS}$ (see recipe), sterile

Macrophage complete medium (see recipe)

$10-\mathrm{cm}$ tissue culture-treated dishes

15- and 50-ml conical tubes (e.g., BD Falcon)

$0.45-\mu \mathrm{m}$ filter unit

Additional reagents and equipment for basic cell culture techniques including trypsinization and counting cells (Phelan, 2006)

CAUTION: Handling of human cell line requires special caution due to possible contamination of human pathogens.

1. On the same day that the bone marrow progenitor cells are harvested (Day 0), seed $4 \times 10^{6} 293$ T cells in a 10-cm tissue culture-treated dish with $10 \mathrm{ml}$ DMEM-10. Make as many dishes as you want to produce lentivirus and set up transduction.

The ideal cell density at the time of transfection is $60 \%$ to $70 \%$ confluency. Too few cells or too many cells can lead to the loss of cells during the harvest and reduced yield of lentiviruses.

2. Day 1: For each 10-cm plate of 293 T cells to be transfected, prepare the following transfection mix in a sterile $15-\mathrm{ml}$ conical tube:

$6.5 \mu \mathrm{g}$ packaging vector

$3.5 \mu \mathrm{g}$ VSV-G pseudotyping vector

$10 \mu \mathrm{g}$ lentiviral vector

3. Add $100 \mu \mathrm{l}$ of $2.5 \mathrm{M} \mathrm{CaCl}_{2}$ and $900 \mu \mathrm{l}$ sterile water to the DNA mix. Mix well by pipetting up and down.

4. To another $15-\mathrm{ml}$ tube, add $1 \mathrm{ml}$ of $2 \times \mathrm{HeBS}$. While vortexing the tube containing $2 \times \mathrm{HeBS}$, add the $\sim 1 \mathrm{ml}$ of $\mathrm{DNA} / \mathrm{CaCl}_{2}$ mix dropwise to the $2 \times \mathrm{HeBS}$ tube.

Set the speed of the vortex to mix vigorously without spilling out the contents.

5. Leave the tube at room temperature for 5 to $30 \mathrm{~min}$ to allow the formation of fine precipitates of DNAs for transfection.

6. While incubating, replace the medium on the 293T cells with $10 \mathrm{ml}$ of fresh DMEM10 .

The medium can be replaced as early as $3 \mathrm{hr}$ before transfection.

7. Add the solution directly from the tube in step 5, containing the precipitate, in a dropwise manner onto the cells (total $\sim 2 \mathrm{ml}$ per plate), covering the whole surface of the plate. Add drops right above the surface of the medium to minimize any impact that can detach 293 T cells from the plate. Shake the plate gently and perpendicularly a couple of times until the medium has recovered a uniform color. Incubate the cells in $37^{\circ} \mathrm{C}, 5 \% \mathrm{CO}_{2}$ incubator for 12 to $16 \mathrm{hr}$.

CAUTION: 2937 cells easily detach from the culture dish.

Animal RNA

Viruses 
ALTERNATE PROTOCOL 5

8. Aspirate the medium and add $7 \mathrm{ml}$ of macrophage complete medium gently to the transfected cells. Incubate the cells in $37^{\circ} \mathrm{C}, 5 \% \mathrm{CO}_{2}$ incubator.

CAUTION: Biosafety Level 2 (BSL-2) practices are required for handling of lentivirus.

9. Twelve hr after medium change, harvest the culture medium from each plate, collect in a 50-ml conical tube, and add $7 \mathrm{ml}$ of fresh macrophage complete medium back to the transfected cells. Incubate the cells in $37^{\circ} \mathrm{C}, 5 \% \mathrm{CO}_{2}$ incubator and store the collected medium at $4^{\circ} \mathrm{C}$.

10. Repeat step 9 two more times every $12 \mathrm{hr}$ and keep the collected culture medium at $4^{\circ} \mathrm{C}$ throughout the collection period. Discard the transfected 293T cells after the third harvest, according to your institutional biosafety regulations.

11. Filter the pooled culture medium ( $\sim 20 \mathrm{ml}$ final per each transfection) using a 0.45 $\mu \mathrm{m}$ filter unit.

The filtered culture medium containing lentivirus can be used directly or concentrated if needed. It can be kept at $4^{\circ} \mathrm{C}$ for a couple of days or $-80^{\circ} \mathrm{C}$ for a long-term storage.

Avoid freezelthaw cycles, as they reduce the titer of lentivirus preparations.

\section{LENTIVIRAL TRANSDUCTION OF MACROPHAGE CELL LINES TO OVER-EXPRESS OR DOWN-REGULATE A GENE OF INTEREST FOR MNV INFECTION}

Lentiviral vectors produced in Support Protocol 6 can be also used to transduce macrophage cell lines (e.g., RAW 264.7 or BV-2) commonly used for the study of MNV to stably over-express or down-regulate genes of interest.

\section{Materials}

Macrophage cell lines: RAW 264.7 (ATCC cat. no. TIB-71) or BV-2 (Blasi et al., 1990)

DMEM-10 medium (see recipe)

Lentiviral vectors (Support Protocol 6)

Phosphate-buffered saline (PBS), pH 7.4, sterile (e.g., Life Technologies, cat. no.10010-023)

Selection drug (optional; e.g., puromycin)

$10-\mathrm{cm}$ dishes, tissue-culture treated

Sterile cell lifter (e.g., Fisher Scientific, cat. no. 08100 240)

Additional reagents and equipment for counting cells (Phelan, 006)

1. Seed $4 \times 10^{6}$ RAW 264.7 cells or $2 \times 10^{6}$ BV- 2 cells in $10 \mathrm{ml}$ DMEM- 10 in a tissue culture-treated 10-cm dish approximately $24 \mathrm{hr}$ before transduction.

The expected cell density at the time of transduction is $30 \%$ to $40 \%$ confluency.

2. On the day of transduction, add half of the lentiviruses $(\sim 10 \mathrm{ml})$ produced in Support Protocol 6 onto the $10-\mathrm{cm}$ dish of macrophage cell lines. Incubate for 3 days in $37^{\circ} \mathrm{C}$, $5 \% \mathrm{CO}_{2}$ incubator.

In general, for efficient transduction without titration of the produced lentivirus, match the size of plate of cells for transduction to the size of plate for the preparation of lentivirus. If necessary, scale down the size of plates for both lentivirus production and transduction proportionally. Biosafety Level 2 (BSL-2) practices are required for handling of lentivirus.

Murine Norovirus: Propagation, Quantification, and Genetic Manipulation

15K.2.46
3. Three days later, discard the culture medium containing lentivirus, wash once with $10 \mathrm{ml}$ PBS, and add $5 \mathrm{ml}$ of cold DMEM-10. Scrape off the cells with cell lifter, add an additional $5 \mathrm{ml}$ of cold DMEM-10, resuspend the cells by pipetting up and 
down, and transfer them to a 50-ml conical centrifuge tube. Count the number of cells (Phelan, 2006).

The transduced cells can be analyzed directly at this time or they can be replated for further selection by the expression of a reporter gene (e.g., green fluorescent protein from $\mathrm{pCDH}$ MCS-T2A-copGFP-MSCV) or drug-resistance gene (e.g., puromycin $N$-acetyltransferase from pLKO.1 puro).

4. Optional: For the drug selection of transduced cells, replate cells at $1 \times 10^{6} \mathrm{RAW}$ 264.7 cells or $0.5 \times 10^{6}$ of BV-2 cells per well in $2 \mathrm{ml}$ of DMEM-10 for 6-well tissue culture plates. At $\sim 24 \mathrm{hr}$ after seeding, add drug (e.g., $5 \mu \mathrm{g} / \mathrm{ml}$ puromycin) for 3 days.

The selective concentration of drug for individual cell lines should be titrated before the selection in a pilot experiment. The duration and frequency of drug treatment should be adjusted depending on the degree of cell death, since too much cell death can cause false negative results.

\section{TRANSFECTION OF INFECTIOUS VIRAL RNA INTO MOUSE EMBRYONIC FIBROBLASTS}

Macrophages and dendritic cells are the only reported cell types that can be infected by MNV (Wobus et al., 2004). However, as shown in the example of reverse genetics systems for MNV, MNV can replicate in many other cell types as long as its infectious genome is delivered into host cells (Yunus et al., 2010). For example, mouse embryonic fibroblasts (MEFs) are one cell type that cannot be infected by MNV but can support MNV replication (Hwang et al., 2012). MEFs isolated from genetically manipulated mouse lines are a valuable tool to study the function of mutated genes for viral replication under well-defined culture condition. In this protocol, viral RNA of MNV purified from concentrated viral stock (Support Protocol 7) is transfected into MEFs (Support Protocol 8) by Lipofectamine 2000 to produce infectious MNV. The procedure optimally yields $\sim 5 \times 10^{6}$ plaque-forming units of MNV per $1 \mu \mathrm{g}$ of transfected viral RNA.

\section{Materials}

MEFs (Support Protocol 8)

DMEM-10 medium (see recipe)

Opti-MEM I medium (Invitrogen)

Viral RNA of MNV (Support Protocol 7)

Lipofectamine 2000 (Life Technologies)

24-well tissue culture-treated plates

1. Seed $1 \times 10^{4}$ MEF cells in $1 \mathrm{ml}$ DMEM-10 per well in tissue culture-treated 24-well plates $\sim 24 \mathrm{hr}$ before transfection.

The expected cell density at the time of transfection is 30\% to $40 \%$ confluency. $0.5 \mathrm{ml}$ medium per well will be sufficient for 24-well plates, but $1 \mathrm{ml}$ medium is recommended for even distribution of cells on the plate. Clumped cells significantly lower the transfection efficiency and viral yield. If necessary, drugs (e.g., interferon $\gamma$ ) can be used to treat cells at $12 \mathrm{hr}$ prior to transfection.

2. On the day of transfection, prepare transfection mix as follows according to the manufacturer's instruction:

a. Dilute 0.2 to $0.5 \mu \mathrm{g}$ of infectious viral RNA in $50 \mu \mathrm{l}$ of Opti-MEM I medium. Mix gently.

Handling of RNA requires extra caution to minimize any possible contamination with RNase and subsequent degradation of RNAs. 
SUPPORT PROTOCOL 7
Murine

Norovirus:

Propagation, Quantification,

and Genetic

Manipulation

b. Mix Lipofectamine 2000 gently by inverting the tube three times and dilute $2 \mu 1$ in $50 \mu \mathrm{l}$ of Opti-MEM I medium. Mix gently by swirling and incubate for 5 min at room temperature.

c. After the 5-min incubation, combine the diluted RNA with the diluted Lipofectamine 2000. Mix gently by swirling and incubate for $20 \mathrm{~min}$ at room temperature.

3. Add the $100 \mu$ l of RNA-Lipofectamine 2000 complexes to each well of cells and mix gently by rocking the plate perpendicularly a couple of times.

4. Incubate cells at $37^{\circ} \mathrm{C}$ in a $5 \% \mathrm{CO}_{2}$ incubator for $24 \mathrm{hr}$.

5. To harvest MNV, freeze/thaw the entire 24 -well plate by placing it at $-80^{\circ} \mathrm{C}$ and later at room temperature.

Virus-containing lysate can then be easily transferred into tubes and stored at $-80^{\circ} \mathrm{C}$ for follow-up assays.

Approximately $1 \times 10^{6}$ plaque forming units of $M N V$ are produced per transfection (Hwang et al., 2012). Other liposome-mediated transfection reagents may be used, but Lipofectamine 2000 worked most reproducibly and produced the highest titer of viruses.

\section{PREPARATION OF INFECTIOUS VIRAL RNA FROM MNV STOCK}

Infectious viral RNA of MNV can be extracted directly from concentrated viral stocks (Support Protocol 1) using the standard TRIzol method. The genome-linked VPg protein, which is essential for the translation of viral RNA, stays functional after RNA preparation with TRIzol unless the RNA is treated with proteases.

\section{Materials}

Concentrated MNV virus stock (Support Protocol 1)

TRIzol (Life Technologies) or TRI Reagent (Sigma)

Chloroform

Isopropanol

$75 \%$ ethanol

RNase-free $\mathrm{H}_{2} \mathrm{O}$ (APPENDIX 2A, or purchase, e.g., from Invitrogen)

Water bath or heat block $\left(55^{\circ}\right.$ to $\left.60^{\circ} \mathrm{C}\right)$

1. Prepare concentrated MNV virus stock (Support Protocol 1) and add appropriate volume of TRIzol to homogenize, according to the manufacturer's instruction.

Concentrated viral stock is recommended as starting material for better estimation of viral yield upon transfection of infectious viral RNA. However, a regular MNV stock can also be used as starting material.

Depending on the type of TRIzol used (e.g., TRIzol versus TRIzol LS), adjust the volume of added TRIzol. This protocol is based on the use of regular TRIzol, and thus 10 volumes (i.e., $1 \mathrm{ml}$ for $0.1 \mathrm{ml}$ viral stock) of TRIzol are used.

2. Incubate the homogenate at room temperature for $5 \mathrm{~min}$, then add $0.2 \mathrm{ml}$ chloroform per $1 \mathrm{ml}$ of TRIzol used.

3. Shake the samples vigorously for $15 \mathrm{sec}$, then incubate the resulting mixture at room temperature for 2 to $3 \mathrm{~min}$.

4. Centrifuge the samples $15 \mathrm{~min}$ at $12,000 \times g, 4^{\circ} \mathrm{C}$.

Centrifugation at $4^{\circ} \mathrm{C}$ is essential for clear phase separation. 
5. Transfer the aqueous phase (transparent solution on top of pink solution) to a new microcentrifuge tube.

The volume of the aqueous phase will be $\sim 60 \%$ of the volume of TRIzol used.

6. Add $0.5 \mathrm{ml}$ of isopropanol per $1 \mathrm{ml}$ of TRIzol used initially, and incubate at room temperature for $10 \mathrm{~min}$ to precipitate RNA.

7. Centrifuge $10 \mathrm{~min}$ at $12,000 \times g, 4^{\circ} \mathrm{C}$, and remove the supernatant.

The pellet of viral RNA may or may not be visible on the centrifugal side of the tube, depending on the amount of starting material used. Try not to touch the centrifugal side while removing the supernatant.

8. Add $1 \mathrm{ml}$ of $75 \%$ ethanol, per $1 \mathrm{ml}$ of TRIzol used, to the centripetal side of the tube. Mix the sample by inverting the tube a couple of times and centrifuge $5 \mathrm{~min}$ at $7500 \times g, 4^{\circ} \mathrm{C}$.

9. Remove supernatant, spin the tubes briefly again, and remove as much remaining supernatant as possible.

Another brief centrifugation is recommended to bring down any residual ethanol on the side of tube and thus to remove the ethanol wash more effectively.

10. Air-dry the RNA at room temperature for $5 \mathrm{~min}$, add the appropriate volume of RNase-free water to the centrifugal side of the tube, and incubate the samples at $60^{\circ} \mathrm{C}$ for $15 \mathrm{~min}$. Keep the tubes with dissolved RNA on ice while measuring the concentration of RNA, and then keep the RNA at $-80^{\circ} \mathrm{C}$ until used.

\section{PREPARATION OF MOUSE EMBRYONIC FIBROBLAST CELLS}

MEFs are usually isolated from mouse embryos at embryonic day 13.5 (E13.5) to E15.5, but it can be prepared as early as E8.5 if the embryos have lethal mutations. It is recommended to prepare both control MEFs and mutant MEFs from mice with same backgrounds to minimize phenotypic variation due to different genetic background.

NOTE: All protocols involving live animals must be reviewed and approved by an Institutional Animal Care and Use Committee (IACUC) and must conform to government regulations for the care and use of laboratory animals.

\section{Materials}

Pregnant female mouse

Phosphate-buffered saline (PBS), pH 7.4, sterile (e.g., Life Technologies, cat. no.10010-023)

$70 \%$ ethanol

DMEM-10 medium (see recipe)

Trypsin/EDTA (e.g., Cellgro, cat. no. 25-053-CI)

Dimethylsulfoxide (DMSO)

10-cm petri dishes

Dissecting instruments

10-ml syringe, sterile

$175-\mathrm{cm}^{2}$ tissue culture flasks

50-ml conical tubes (e.g., BD Falcon)

Additional reagents and equipment for mouse euthanasia (APPENDIX $3 N$ ) and immortalization of fibroblasts $(\mathrm{Xu}, 2005)$

1. Prepare two $10-\mathrm{cm}$ petri dishes with $20 \mathrm{ml}$ of PBS.

Animal RNA

Viruses 
2. Euthanize a pregnant female mouse with embryos of desired genetic background according to the guidelines of the home institution (e.g., $\mathrm{CO}_{2}$ asphyxiation, then cervical dislocation; see APPENDIX $3 N$ ). Briefly sterilize the euthanized mouse either by spraying sufficient $70 \%$ ethanol to cover the whole body or by soaking the mouse in $70 \%$ ethanol.

Dissection in a clean environment (e.g., inside biosafety cabinet) is recommended to minimize any contamination.

3. Cut through and peel off abdominal skin and open peritoneum. Dissect out the entire uterus containing all embryos without damaging the other internal organs and transfer the uterus to a $10-\mathrm{cm}$ petri dish with PBS.

Damaging the other internal organs, especially intestines, can lead to bacterial contamination.

4. Remove the mouse carcass, clean up the biosafety cabinet, and get a new pair of gloves and sterile equipment if necessary.

If the dissection equipment is going to be used again, make sure to clean and sterilize with $70 \%$ ethanol.

5. Cut out the uterine wall and take out individual embryos. Transfer all embryos into the other 10-cm dish with $20 \mathrm{ml}$ PBS.

Remove maternal materials as much as possible, especially when the genetic background of embryos differs from that of their mother (e.g., embryo with homozygous genetic knock-out from heterozygous mother).

6. Count the number of embryos, and prepare new 10-cm dishes with $10 \mathrm{ml}$ PBS each (prepare twice as many dishes as the number of embryos).

7. Transfer each embryo individually into a $10-\mathrm{cm}$ dish. Remove and discard internal organs, limbs, and head of embryo. Transfer the torso of each embryo to a new 10-cm dish with PBS.

Keep a small piece of a discarded part of the embryo for DNA extraction and subsequent genotyping if necessary.

8. Using the plunger from a 10-ml syringe, crush the torso as much as possible. Resuspend the crushed pieces with PBS and transfer them to a 15-ml tube. Centrifuge $5 \mathrm{~min}$ at $300 \times g$, room temperature.

9. Discard supernatant and resuspend the pellet with $10 \mathrm{ml}$ DMEM-10. Transfer the resuspended pieces of the crushed embryo into a $175-\mathrm{cm}^{2}$ flask and add $20 \mathrm{ml}$ more DMEM-10.

10. Incubate the flask in $37^{\circ} \mathrm{C}, 5 \% \mathrm{CO}_{2}$ incubator for 7 days.

MEFs grow out from the tissue debris of the crushed embryo. Shake the flask once a day to spread out the tissue debris for maximal use of the space and even distribution of MEFs in the flask.

11. Discard medium and loosely bound debris. Add $30 \mathrm{ml}$ PBS to the flask and swirl it to detach any loosely bound debris. Discard PBS and any debris and add $5 \mathrm{ml}$ of trypsin/EDTA. Incubate the flask at $37^{\circ} \mathrm{C}$ for $5 \mathrm{~min}$.

12. Resuspend the cells with $25 \mathrm{ml}$ more DMEM-10 medium and transfer to $50-\mathrm{ml}$ conical tube.

At this stage, if necessary, any remaining clumps or debris can be removed by allowing them to settle down by gravity for $\sim 1$ min. Transfer the remaining cell suspension to a new tube. 
13. Centrifuge $5 \mathrm{~min}$ at $300 \times g$, room temperature. Discard supernatant and resuspend the pellet with $30 \mathrm{ml}$ DMEM-10. Split the resuspended cells into three $175-\mathrm{cm}^{2}$ flasks and add $20 \mathrm{ml}$ more DMEM-10 to each flask. Incubate the flask in $37^{\circ} \mathrm{C}, 5 \%$ $\mathrm{CO}_{2}$ incubator for 2 days.

These are the passage 1 (P1) MEFs.

14. Upon confluency (usually, in 2 days), subculture the P1 MEFs for experiments or freeze them down $\left(5 \times 10^{6}\right.$ cells/vial in DMEM-10 with $10 \% \mathrm{v} / \mathrm{v}$ DMSO). Use the primary MEFs until P5 (based on 1:3 split).

The typical yield of P1 MEFs is $\sim 2-3 \times 10^{7}$ cells per embryo.

15. To make a stable line of MEF, immortalize the MEFs (Xu, 2005) either by seriaxl passage (20 to 25 times) or transformation with oncogene (e.g., SV40 large T antigen).

\section{REAGENTS AND SOLUTIONS}

Use deionized, distilled water for all recipes and protocol steps unless otherwise specified. For common stock solutions, see APPENDIX 2A; for suppliers, see SUPPLIERS APPENDIX.

\section{CMG14-12 conditioned medium}

CMG14-12 (Takeshita et al., 2000) is a mouse $\mathrm{Ltk}^{-}$cell line expressing large amounts of murine M-CSF. CMG14-12 cells [can be obtained from Dr. Seungmin Hwang, Dept. of Pathology, University of Chicago, with written permission from Dr. A. Kudo (akudo@bio.titech.ac.jp)] are cultured in $\alpha$-MEM until confluent. CMG14-12 conditioned medium is then harvested every other day, five times. Culture supernatants are filtered through a $0.22-\mu \mathrm{m}$ nitrocellulose filter, divided into $\sim 50-\mathrm{ml}$ aliquots, and stored at $-80^{\circ} \mathrm{C}$ until use.

\section{DMEM-10 medium, complete}

High glucose DMEM supplemented with:

$10 \%(\mathrm{v} / \mathrm{v})$ low-endotoxin fetal bovine serum $(<10 \mathrm{EU} / \mathrm{ml})$

$10 \mathrm{mM}$ HEPES

$100 \mathrm{U} / \mathrm{ml}$ penicillin

$100 \mu \mathrm{g} / \mathrm{ml}$ streptomycin

$1 \mathrm{mM}$ nonessential amino acids

$2 \mathrm{mM}$ L-glutamine

Store up to 4 weeks at $4^{\circ} \mathrm{C}$

\section{ELISA blocking buffer}

Supplement ELISA coating buffer (see recipe) with 3\% (w/v) BSA. Prepare fresh.

\section{ELISA coating buffer}

$1.53 \mathrm{~g}$ disodium trioxocarbonate (IV) (sodium carbonate; $\mathrm{Na}_{2} \mathrm{CO}_{3}$ )

$2.93 \mathrm{~g}$ sodium hydrogen trioxocarbonate (IV) (sodium bicarbonate; $\mathrm{NaHCO}_{3}$ )

Check pH (should be $\mathrm{pH} 8.8$ to 9.6), then bring to 1 liter with $\mathrm{H}_{2} \mathrm{O}$

Store up to 3 months at room temperature

\section{ELISA substrate buffer}

To make 2 liters:

25.6 g citric acid

continued 
$25.6 \mathrm{~g}$ disodium hydrogen tetraoxophosphate $(\mathrm{V})\left(\mathrm{Na}_{2} \mathrm{HPO}_{4}\right)$

Adjust $\mathrm{pH}$ to 4.2, bring to 2 liters with Milli-Q $\mathrm{H}_{2} \mathrm{O}$

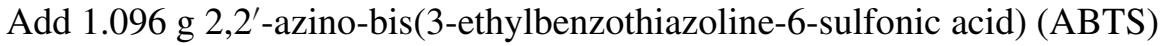

Aliquot $12 \mathrm{ml} /$ tube and store at $-20^{\circ} \mathrm{C}$

Add $12 \mu 130 \%$ hydrogen peroxide $\left(\mathrm{H}_{2} \mathrm{O}_{2}\right)$ right before adding to ELISA plate

Buffer composition: $0.1 \mathrm{M}$ sodium citrate/1 mM ABTS/0.016\% (v/v) $\mathrm{H}_{2} \mathrm{O}_{2}$.

\section{ELISA III buffer}

$0.15 \mathrm{M}$ sodium chloride $(\mathrm{NaCl})$

$0.001 \mathrm{M}$ ethylenediaminetetraacetic acid (EDTA)

$0.05 \mathrm{M}$ Tris hydrochloride

$0.05 \%$ (v/v) Tween 20

Adjust $\mathrm{pH}$ to 7.4

Bring to 1 liter with $\mathrm{H}_{2} \mathrm{O}$

Add BSA to $0.1 \%(\mathrm{w} / \mathrm{v})$

Store up to 3 months at room temperature

\section{ELISA wash buffer}

$0.15 \mathrm{M} \mathrm{NaCl}$

$0.05 \%$ Tween 20

Store up to 3 months at room temperature

\section{HEPES-buffered saline (HeBS), $2 \times$}

Dissolve the following reagents in $800 \mathrm{ml}$ of molecular biology-grade water:

$16.36 \mathrm{~g} \mathrm{NaCl}$ (mol. wt. 58.44, $0.28 \mathrm{M}$ final)

11.9 g HEPES (mol. wt. 238.3, $0.05 \mathrm{M}$ final)

$0.213 \mathrm{~g}$ anhydrous $\mathrm{Na}_{2} \mathrm{HPO}_{4}$ (mol. wt. $142,1.5 \mathrm{mM}$ final)

Adjust pH to 7.05 with $5 \mathrm{M} \mathrm{NaOH}$

Add more molecular biology-grade $\mathrm{H}_{2} \mathrm{O}$ to $1000 \mathrm{ml}$ final

Filter sterilize through a $0.22-\mu \mathrm{m}$ nitrocellulose filter

Divide into 50-ml aliquots

Store at $4^{\circ} \mathrm{C}$ for short-term use or at $-20^{\circ} \mathrm{C}$ for long-term storage

An exact $p H$ is extremely important for efficient transfection. The optimal $p H$ range is 7.05 to 7.12. There can be wide variability in the efficiency of transfection obtained between different batches of $2 \times$ HeBS. Efficiency should be checked with each new batch.

\section{Macrophage complete medium}

Add the following reagents to $700 \mathrm{ml}$ of Dulbecco's modified Eagle medium (DMEM):

$100 \mathrm{ml}$ fetal bovine serum (FBS)

$50 \mathrm{ml}$ horse serum

$10 \mathrm{ml} 200 \mathrm{mM}$ L-glutamine

$10 \mathrm{ml}$ of $100 \mathrm{mM}$ sodium pyruvate

$100 \mathrm{ml}$ of CMG14-12 conditioned medium [see recipe; equivalent to mouse

M-CSF or L-929 conditioned medium (Stanley et al., 1983)]

Adjust volume to $1000 \mathrm{ml}$ with DMEM

Store up to 2 months at $4^{\circ} \mathrm{C}$

Murine Norovirus: Propagation, Quantification, and Genetic Manipulation

\section{MEM medium, $2 \times$, complete}

$2 \times$ MEM (Life Technologies, cat. no. 11935) supplemented with:

$10 \%(\mathrm{v} / \mathrm{v})$ low-endotoxin fetal bovine serum $(<10 \mathrm{EU} / \mathrm{ml})$

continued 
$10 \mathrm{mM}$ HEPES

$100 \mathrm{U} / \mathrm{ml}$ penicillin

$100 \mu \mathrm{g} / \mathrm{ml}$ streptomycin

$4 \mathrm{mM}$ L-glutamine

Equilibrate to $37^{\circ} \mathrm{C}$ before use

Store at $4^{\circ} \mathrm{C}$ for up to 1 month

\section{Seaplaque agarose, $3 \%$}

Add $3 \mathrm{~g}$ of SeaPlaque agarose (Lonza, cat no. 50100) in a total volume of $100 \mathrm{ml}$ of distilled water $(3 \% \mathrm{w} / \mathrm{v})$ in a glass bottle. Autoclave 20 to $30 \mathrm{~min}$ (it is important to equilibrate SeaPlaque agarose to $42^{\circ} \mathrm{C}$ in a water bath before use). Store autoclaved Seaplaque up to 1 month at room temperature and reheat in microwave prior to use.

\section{COMMENTARY}

\section{Background Information}

MNV reverse genetics: Reverse genetics serves as a cornerstone for unraveling the life cycle of many viruses, allowing the recovery of genetically defined wild-type or mutant strains, making it a very important tool in modern virology. As other reverse genetics systems were established for other members of the Caliciviridae family, efforts have been made to introduce a system with MNV, resulting in a total of three reverse genetics systems to date (Chaudhry et al., 2007; Ward et al., 2007; Yunus et al., 2010). The two DNA-based reverse genetics systems rely on either the DNA polymerase II promoter or the $\mathrm{T} 7$ polymerase promoter to drive expression of viral cDNA after transfection of a DNA plasmid containing the full-length MNV genome into easily transfectable cells, typically HEK293T cells. The method by Ward et al. (2007) (see Basic Protocol 3) relies on the use of a DNA polymerase II promoter to generate a capped transcript. Another method which has proven successful for the recovery of FCV is the transcription of RNA from transfected cDNA, driven by the T7-RNA polymerase from vaccinia virus (MVA-T7; Geissler et al., 1999). However, this method failed when applied to the recovery of MNV, as MVA-T7 replication interferes with the translation and replication of MNV (Chaudhry et al., 2007). Therefore, Alternate Protocol 2, based on FPV-T7, constitutes an improved modification of initial attempts carried out with MVA-T7. Although both FPV and MVA are members of the Poxviridae family, FPV displays a tropism only for avian cells, and its replication in mammalian cells is defective. This allows the production of the T7 RNA polymerase, which drives the synthesis of the transfected MNV cDNA via the T7 promoter without interfering with MNV translation and replication as observed with MVA-T7. Generating infectious MNV from

cDNA cannot be undertaken using cell lines in which MNV is known to replicate, such as RAW 264.7 cells, due to difficulties transfecting these cells. Instead, commonly used transfectable cell lines can be used to recover the virus, mainly HEK293T cells, but HepG2, BHK-21, or COS-7 cells have also been tested (Chaudhry et al., 2007; Ward et al., 2007). BSR-T7 is a cell line derived from BHK-21 stably expressing T7 RNA polymerase. However, the expression of T7 RNA polymerase in these cells is insufficient to recover MNV from cDNA. This might be due to the low T7 RNA polymerase expression levels detected in these cells compared to FPV-T7 infected cells, along with the absence of capping enzymes provided by FPV-T7 that could be providing a cap to the produced MNV transcripts. Since the transfectable cell lines are not susceptible to MNV infection, however, reported titers represent a single replication cycle and can provide information on the fitness of the recovered virus.

The RNA-based reverse genetic system (Basic Protocol 4) described herein represents the most efficient recovery of genetically defined MNV in cell culture compared to DNAbased reverse genetics systems. The transfection of capped RNA, which can be recognized by the cellular translation machinery, effectively bypasses the absolute requirement for the covalent linkage of VPg to the $5^{\prime}$ end of the viral RNA genome (Yunus et al., 2010). When transfected into BV-2 cells, virus titers recovered with RNA-based reverse genetics systems are similar to those obtained by transfection of viral VPg-linked RNA purified from infected cell cultures (Chaudhry et al., 2007; Yunus et al., 2010). A more direct and often more cost effective method for the recovery of infectious MNV from capped RNA transcripts is via transfection into permissive
Animal RNA Viruses 
BSR-T7 cells. Given that BV-2 cells or RAW 264.7 cells are difficult to transfect using lipidbased approaches, other cell lines can be used, such as BSR-T7 cells, a derivative of the BHK21 cell line. These cells are easy to transfect and are permissive to MNV replication, but do not allow multiple rounds of infection. There are other cell lines also suitable to this approach, including human $293 \mathrm{~T}$ cells, human hepatocellular carcinoma Huh7 cells, and African green monkey Cos7 cells.

MNV qRT-PCR: A quantitative polymerase chain reaction (qPCR) is a modification of the polymerase chain reaction (PCR), where amplification and simultaneous quantification of one or more targeted DNA sequences is achieved (Higuchi et al., 1992). Additionally, quantitation and amplification can be visualized in real time because the assay is fluorescence-based, which, with the proper controls, can allow for detection of absolute levels of template (Higuchi et al., 1992; Bustin et al., 2009). The technique originally arose in the 1990s (Higuchi et al., 1992) when it was observed that ethidium bromide had the capacity to fluoresce and that this fluorescence increased in the presence of double-stranded DNA. This fluorescence could be monitored externally and could allow for determination of nucleic acid quantity. Thus, the ability to simultaneously amplify specific DNA sequences and detect the product of the amplification allowed this technique to revolutionize modern molecular biology.

Quantitative polymerase chain reaction has the capacity to detect nucleic acids in a wide range of samples from numerous sources: mammalian eukaryotic single cells and tissues, plant cells and tissues, prokaryotes, stool samples, and complex fluids (e.g., blood, plasma, saliva). The quantity of amplified DNA can then be calculated as either an absolute number of copies or a relative amount when normalized to input DNA input or additional normalizing genes/parameters. Additionally, the technique has been modified to make it safer for handling by utilizing alternate fluorophores, such as fluorescein, that are minimally if at all toxic. This has made the technique easier and more accessible, to the point of allowing several modifications of it to flourish.

Different kinds of qPCR have been developed in the past years. For example, multiplex qPCR allows for the simultaneous detection of more than one nucleic acid sequence in a single tube through the use of specific fluorescent probes targeting each sequence individually. If no specific probes are available, the use of the double-stranded DNA-binding dye SYBR Green can allow for amplicon detection. qPCR has also been modified to include a coupled reverse transcription step (RTqPCR) where RNA is used as the starting template, converted to cDNA, and then subsequently amplified. The technology is usually able to estimate mRNA abundance/gene expression with a remarkable degree of certainty and sensitivity. Indeed, this sensitivity of the technique, for example, can be assessed when comparing it to older methods of measuring nucleic acid abundance (e.g., northern blotting for mRNA). In contrast to older techniques, it requires minimal amounts of template and is reliable over a greater dynamic range of RNA concentration.

\section{Critical Parameters and Troubleshooting}

\section{Propagation and purification of MNV}

i. Healthy cells are a prerequisite for optimal virus growth. Cells should be split at least twice after thawing before using them for virus infections. RAW 264.7 cells do not grow to $100 \%$ confluency. Instead cells will grow on top of each other and clump. Thus, cells should be split at $\sim 90 \%$ confluency before they pile up.

ii. Not all MNV strains cause the clear CPE seen with MNV-1. For those strains, it may be necessary to determine the optimal time of harvest by performing a viral growth curve (i.e., infect cells with $\mathrm{MNV}$ as described in Basic Protocol 1 and take samples every 6 to $12 \mathrm{hr}$ to determine viral titers).

iii. If the yield of purified virus is low, check the starting titer of your virus stock. Thus, is it advisable while optimizing the protocol to save a few microliters of virus at each step of the protocol to check for increase in purity and/or virus titer.

\section{MNV ELISA}

i. The development time should not exceed $10 \mathrm{~min}$, as eventually all samples will turn color.

ii. Plates should not dry out. If multiple ELISA plates are processed at one time, let plates sit in wash buffer, then flick out the buffer one plate at a time and add new solution to the plate before proceeding to the next plate.

\section{DNA-based, pol II-driven generation of recombinant MNV}

i. Increasing DNA concentration might improve the transfection efficiency. 
ii. Incubation times are crucial. You need to find a good balance in having long transfection times and keeping the cells happy. If you change the medium after $24 \mathrm{hr}$, keep the supernatant and test it for virus.

iii. Make sure you do not have plasmid contamination in your analysis should you use RT-PCR on recombinant virus that does not plaque.

iv. Make sure you have healthy 293T cells; maybe test EGFP transfection efficiency first (especially when using new serum). Mycoplasma contamination negatively affects transfection efficiency, and you do not want them in your virus preps anyway.

v. You may want to keep 293T and RAW 264.7 cell medium separate. 293 T easily get contaminated with mycoplasma.

vi. Make sure you have true 293T-if 293Ts change their behavior over time, e.g., they do not come off surfaces easily anymore, this could be HeLa cell contamination (the two cell lines look pretty much identical).

vii. 293T are bad cells for immunofluorescence, since they come off easily and change shape during treatment.

\section{DNA-based, T7-driven generation of recombinant $M N V$}

i. Seeding density: This protocol is optimized for the use of BHK or its derivative cell line, BSR-T7. The seeding densities described for these two cell lines are designed to provide a confluent cell monolayer for transfection with Lipofectamine 2000. The correct seeding density should be determined for any other cell line that is to be used. All these transfectable cell lines are permissive to MNV replication, but they are not susceptible to infection as they cannot be infected by MNV; thus, the virus yields obtained represent that from a single round of replication.

ii. cDNA transfection: The quality of the cDNA prepared can affect the recoveries. DNA preparations must be clear of any contaminating endotoxin for optimal transfection efficiency.

iii. FPV-T7 titration: The FPV-T7 should be titrated before use and used to inoculate cells at a multiplicity of infection of 0.5 $\mathrm{pfu} / \mathrm{cell}$, based on the titer in primary CEFs. Otherwise, a higher multiplicity of infection can affect cell viability while a lower multiplicity of infection can result in insufficient cells infected and insufficient T7 polymerase expression. Both scenarios can affect virus yields. iv. The titration of an FPV-T7 stock generated as mentioned above is performed by plaque assay in CEFs under solid overlay containing $1 \%$ agarose, as previously described (Buttigieg et al., 2013). Typically, a functional titration of the newly generated virus stock is performed. To this end, we compare MNV recovery yields of a well-characterized stock of FPV-T7 with the new preparation to ensure batch-to-batch comparability. Additional options for titration other than plaque assay in primary CEFs include the use of an immunofocal assay for T7 RNA polymerase or the use of a reporter assay reliant on luciferase expression under the control of a T7 RNA polymerase promoter.

v. Low titers of infectious MNV can be due to a variety of reasons. Either poor transfection efficiency or a cDNA clone that carries deleterious mutations can culminate in low recovery yields. To determine the cause of low titers, a duplicate for each recovery should be performed. One sample would to be used to titer the recovered virus, while the other would be tested for protein extraction. NS7 detection by western blot permits the analysis of protein expression levels; a weak signal may signify a low transfection efficiency, resulting in low virus titers. If this is the case, first check the integrity of the cDNA clone using restriction digestion and sequencing. Then, ensure that the purity of the DNA is sufficient, and finally use different ratios of cDNA:Lipofectamine and/or extended incubation periods to improve the efficiency of virus recovery. Conversely, detecting a strong signal for NS7 is a sign of good transfection efficiency. Hence, lower virus yields than in wild-type preparations typically suggests that the viral cDNA encodes for a lower fitness virus.

\section{RNA-based generation of recombinant MNV}

i. The quality of linearized MNV cDNA and subsequently synthesized genomic RNA are the key parameters for effective recovery of infectious MNV.

ii. Ensure an RNase-free environment is maintained throughout the protocol. Degradation of RNA will compromise the final yield and may lead to failure to recover infectious viral particles.

iii. Adhere to the step annotations in the protocol for key advice at each stage.

iv. During the Neon-mediated transfection of RNA into BV-2 cells, it is important to prevent the formation of bubbles when pipetting. Introduction of bubbles during the
Animal RNA Viruses 
electroporation will compromise the cell viability and have negative impact on the final yield of recovery.

v. If infectious MNV fails to be recovered, check first whether the capped RNA used for transfections remained intact. Also, western blot analysis against the viral proteins (e.g., NS7 Pol) may be used to confirm whether the transfection is successful. The cytopathic effect (CPE) of MNV on BV-2 cells after $>24 \mathrm{hr}$ post transfection is another indicator of successful transfection and production of infectious virus. It is worth noting, however, that it is possibe that mutant viruses may replicate without causing CPE. In this situation, viral RNA should be detected and can be quantified by qRT-PCR; viral protein expression should be confirmed by western blot.

\section{TCID $_{50}$}

The most common source of error in this protocol is accidental contamination and carry-over of virus from one dilution to another, or the contamination of the medium or cells used for diluting the virus. To avoid this, plate out the cells in the test plates ahead of time, and be sure to exchange tips at each dilution, and between samples. Performing the $\mathrm{TCID}_{50}$ with a mock sample after the virus samples should highlight if crosscontamination has occurred.

\section{Plaque assay}

i. Healthy RAW 264.7 cells are critical for the success of this assay. Do not let cells overgrow, as those cells do not typically form plaques. Keep track of the passage number and use lower passage cells (we use cells below passage 30).

ii. Do not let cell monolayers dry out. Only process up to five plates at a time.

iii. Carefully count cells when plating, as no plaques form when cells are too sparse or too dense.

iv. If no plaques are visible before staining the monolayer, incubate for an additional $4 \mathrm{hr}$ and check again. The maximum incubation time should not exceed $72 \mathrm{hr}$.

v. If no plaques are visible after staining even at $72 \mathrm{hr}$, check monolayer with light microscope. If all cells are dead, likely the agarose or staining solution was too hot when adding to the monolayer. If cells are healthy, they were likely too dense when plated and unable to form plaques. Alternatively, some MNV strains do not form plaques, or plaques are very small and hard to visualize. In that case use TCID $_{50}$ protocol (Basic Protocol 5).

\section{$M N V q R T-P C R$}

i. For this protocol, reverse transcription can be performed as either a single reaction for cDNA synthesis or coupled to qPCR.

ii. If the sample of interest contains additional expressed RNA (aside from viral RNA) that is to be amplified subsequently, it is best to perform a single reaction for cDNA synthesis using nonspecific primers (e.g., oligo-dT). This is done in order to avoid the worry of RNA degradation if several reactions have to be performed. However, this will only work for polyadenylated mRNA molecules, and can skew the reaction toward the most abundant targets in the sample. If only viral RNA amplification is desired, a single-tube one-step RT-qPCR reaction, where cDNA synthesis is coupled to amplification by the use of genespecific primers, can be performed.

iii. These reactions can be done using home-made reagents, as long as optimization of amplification conditions is performed. However, the use of commercially available mixes, when possible, is recommended, as they contain additives that provide stability to the reaction components and can also allow for faster amplification.

Optimization of qPCR amplification should be performed using the primer/probe matrix method, temperature gradient optimization for annealing, and salt concentration modifications (Lutfalla and Uze 2006; Mikeska and Dobrovic 2009).

iv. High-quality RNA is crucial for efficient amplification and quantification. Follow correct isolation and handling technique.

v. Since PCR amplifies all target nucleic acid, whether from an intact virion, defective (noninfectious) virions, or free nucleic acids in solution, qPCR results (expressed in terms of genome copies $/ \mathrm{ml}$ ) are likely to be higher in than results obtained through other methods of viral detection (e.g., TCID $_{50}$ or plaque assay). This should be kept in mind when analyzing the data.

vi. Although the use of DNA standards is effective in this situation, it is recommended that, whenever possible, in vitro-transcribed RNA be used as the standard for the reaction, since it more accurately reflects the efficiency of reverse transcription that the unknown samples will undergo.

vii. The probe should be protected from light at all times and not stored for long periods of time in too dilute an aliquot.

viii. If no amplification, poor signal, or no signal is seen, you have no detectable PCR product. It could be that there are inhibitors 
present in the reaction, that you used inadequate buffers/master mixes, that you used inadequate cycling conditions, that you forgot the reverse transcription step, or that the probe and/or the template were degraded.

ix. If a signal is detected in the negative controls (e.g., no-template control or no RT control), you may have contamination of your reaction components, primer dimer formation due to wrong cycling steps, or contamination with DNA.

$\mathrm{x}$. In the case of low or high reaction efficiency, there might have been pipetting inaccuracy in making the standards, primer dimer formation if conditions are not optimal (wrong temperature and master mix), or probe quality is bad.

xi. In case the $\mathrm{Cq}$ values of replicate samples are not similar, the most likely cause is pipetting inaccuracy.

\section{Strand-specific RT-qPCR}

i. It is important to accurately measure the standard RNA concentration by UV spectrophotometry. The $\mathrm{OD}_{260}$ of the RNA should be between 0.2 to 0.8 to measure the quantity accurately. If the $\mathrm{OD}_{260}$ is above this range, dilute the RNA in nuclease free water.

ii. As the protocol deals with repetitive pipetting of small volume, care should be taken to minimize the error. Pipets should be carefully calibrated, and care should be taken to ensure that no liquid either adheres to the outside of the tips during pipetting or remains within the tip after mixing of components.

iii. It is important to analyze the melting curve before extrapolating sample copy number from the standard curve. The melting temperature of sample wells should be same as that of standard RNA wells.

iv. It is important to run sufficient negative controls (no-template control) each time, using the same aliquot of nuclease-free water that was used during the protocol.

\section{siRNA transfection of $B V-2$ cells using NEON transfection system}

i. Cells should not stay in Buffer R for more than $15 \mathrm{~min}$. It is important to keep the cells in their appropriate medium until immediately prior to the first centrifugation in PBS.

ii. A number of protocol changes may be required if a reduction in target protein expression is not observed using the standard protocol. Excessive cell death and failure of the transfection may also occur as a result of the formation of bubbles. Extreme care should be taken to ensure this does not occur. Assuming efficient transfection has occurred, examples of changes that may be required include:

a. Design of alternative siRNAs against the target gene.

b. Use of a combination of pooled siRNAs targeting the same gene can be effective.

c. Increasing the concentration of siRNA used to transfect the cells can increase the efficacy of siRNA.

d. Multiple rounds of transfection may also be required, but care should be taken to ensure sufficient cell survival is maintained.

\section{Preparation of primary bone marrow cells}

i. The most common problem in preparing primary cells is contamination by bacteria and fungi. Careful sterilization of equipment and sterile operation techniques are essential to minimize the risk of contamination.

ii. Culturing the primary cells without antibiotics (e.g., penicillin and streptomycin) helps to identify and respond to any contamination of cultures quickly.

\section{Production of lentiviral vector}

i. Although the 293T cell line is highly transfectable, transfection efficiency of 293T cells is the most critical parameter in the production of lentiviral vectors.

ii. The right cell density and good health condition of the $293 \mathrm{~T}$ cells (including low passage) and optimal $\mathrm{pH}$ of $2 \times \mathrm{HeBS}$ are critical factors and need to be well controlled.

\section{Lentiviral transduction of macrophage cell lines}

i. Drug-mediated selection of transduced cells needs a constant monitoring of drug effect and titration of optimal drug concentration, since the screening and subsequent growth of the transduced cells is significantly affected by the death of the other cells and consequent population density.

ii. Too much cell death due to low transduction efficiency can lead to false negative result (i.e., the death of the transduced cells).

iii. On the contrary, a drug is less effective in killing untransduced cells if the population density of treated cells is too high, and this can lead to false positive result (i.e., the survival of the untransduced cells).

\section{Time Considerations}

Generation of MNV-containing lysate: Maximum MNV-1 titers following a low-MOI infection (i.e., MOI 0.05) are reached in $\sim 42$
Animal RNA Viruses 
to $48 \mathrm{hr}$. However, the optimal time has to be individually determined for each MNV strain.

Generation of concentrated MNV stock: The amount of MNV lysate to be concentrated determines the length of time required to concentrate virus. In one day, $\sim 360 \mathrm{ml}$ of lysate can be concentrated (i.e., two centrifuge runs).

MNV purification: Purification takes 2 to 3 days from start to finish. Day 1 is a long day and will be spent spinning down large cellular debris, pelleting and resuspending virus, and preparing the $\mathrm{CsCl}$ gradients. Day 2 will be spent by fractionating the gradient and determining RFI. Alternatively, the procedure can be performed in 3 days. A good stopping point is to incubate the virus pellet with PBS overnight at $4{ }^{\circ} \mathrm{C}$. The gradient will then be prepared on day 2 and fractionated on day 3 .

MNV ELISA: The ELISA assay takes $1 \frac{1}{2}$ days, with the coating of the plates on day 1 , while the rest is done on day 2. If needed, coating times can be extended for several days (e.g., over the weekend).

DNA-based, pol II-driven generation of recombinant MNV: Transfection of a plasmid takes $\sim 30$ min followed by an incubation time of at least $48 \mathrm{hr}$ to generate recombinant virus. Amplification of the recombinant virus on RAW 264.7 cells takes an additional $48 \mathrm{hr}$. The optional step of plaque purification will take 2 days. To verify that the mutation is contained in the virus stock, amplification of the region of interest by RT-qPCR takes another day. Sequencing time for the amplicon depends on the availability of the local sequencing core. Alternatively, samples can be submitted to commercial sequencing facilities, but additional shipping time will need to be taken into account.

DNA-based, T7-driven generation of recombinant MNV: Cell seeding as described in step 1 typically requires $30 \mathrm{~min}$. Cells can be left overnight to settle, or for $3 \mathrm{hr}$ if seeded at double the recommended amount and transfected the same day. Infecting with FPV-T7 and transfecting the cells with desired infectious clones takes a maximum of $3 \mathrm{hr}$. Cells can be left to incubate from 24 to $72 \mathrm{hr}$. After sufficient incubation time, cells can be frozen and stored in $-80^{\circ} \mathrm{C}$ until use. After thawing, cells should be clarified from samples and the virus-containing supernatant can be aliquotted and stored at $-80^{\circ} \mathrm{C}$ for further use.

RNA-based generation of recombinant $M N V$ : Preparation of linearized DNA will take about $4 \mathrm{hr}$ in total, including $3 \mathrm{hr}$ for restriction digestion and purification. In vitro tran- scription can be performed within $8 \mathrm{hr}$ depending on how long the reaction is incubated, the amount of RNA desired, and the method used to assess the RNA integrity. As mentioned above, precipitation using $\mathrm{LiCl}$ can be performed the same day or the precipitates can be left overnight. In vitro enzymatic capping can be performed within $4 \mathrm{hr}$ with subsequent purification. Depending on the methods, the recovery of infectious MNV will take half a day to one day to set up, and up to 3 days will be required to obtain virus particles, based on how many hours post-transfection the viruses are harvested. Obtaining the titer of recovered viruses will generally take 3 to 4 days, depending on which titration method is used.

$\boldsymbol{T C I D}_{50}$ : With practice, a single TCID $_{50}$ can be performed in under $20 \mathrm{~min}$. However, it is common to process large numbers of samples in parallel. For example, TCID $_{50}$ assays of 30 to 40 samples takes 3 to $4 \mathrm{hr}$. This can be noticeably shortened by the use of an electronic multichannel pipet (e.g., an Eppendorf Xplorer Plus) capable of serial dilutions, as this represents the most time-intensive portion of this method.

MNV plaque assay: Plating cells takes approximately $1 \mathrm{hr}$. On the following day, the length of the infection is dependent on the number of samples being analyzed. A typical assay with 30 to 40 samples takes $\sim 3 \mathrm{hr}$ for virus dilutions, infection, and agarose overlay. Plaques are stained 2 to 3 days later, which takes $30 \mathrm{~min}$ for applying the stain, a 2- to 3-hr incubation for staining, and another hour for counting plaques and tabulating virus titers.

MNV qRT-PCR: Time for RNA extraction depends on the number of samples, but if using a kit it should take from 30 min to a couple of hours. DNase treatment typically takes about $45 \mathrm{~min}$ (more if a large number of samples are used). qPCR plate setup should take about $15 \mathrm{~min}$, and the run in the thermal cycler takes about $40 \mathrm{~min}$.

Strand-specific RT-qPCR: The RT step takes $\sim 30 \mathrm{~min}$, and the qPCR program runs for $2 \mathrm{hr}, 40 \mathrm{~min}$. To analyze 10 experimental samples and standard curve samples, the complete protocol can be achieved in 4 to $5 \mathrm{hr}$.

siRNA Transfection of $B V-2$ cells using NEON transfection system: Allow $\sim 1 \mathrm{hr}$ to complete this protocol for a single siRNA transfection and the relevant siRNA transfection control.

Lentiviral transduction of primary bone marrow derived macrophages for MNVinfection: Harvesting bone marrow progenitor cells 
from a mouse should take less than $30 \mathrm{~min}$. Transfection into a $10-\mathrm{cm}$ dish of 293T cells takes about $40 \mathrm{~min}$ and each harvesting should take less than 1 min per dish. Filtration of the final lentiviral vector preparation takes about $5 \mathrm{~min}$ per virus. If bone marrow progenitor cells and transfectable 293T cells are prepared on Day 0, the 293T cells is transfected on Day 1 and the resulting lentiviral stocks are harvested Day 2 and 3. Bone marrow-derived macrophages are transduced on Day 4 and 5 and are ready for replating on Day 7 (Day 9 in case of drug selection). The transduced cells become ready for MNV infection at 3 days after replating.

Transfection of infectious viral RNA into MEFs: Isolating embryos from a pregnant female mouse and setting up culture for MEF takes less than $2 \mathrm{hr}$. An additional 9 days are required to generate passage-1 MEFs from the day of embryo isolation. Extraction of infectious viral RNA from the concentrated stocks of MNV takes about $1 \mathrm{hr}$. The transfection of the viral RNA into MEFs takes about $40 \mathrm{~min}$, and generation of infectious MNV from the transfected MEFs takes a day.

\section{Acknowledgements}

Work in the laboratory of C.E.W. was supported by National Institutes of Health (NIH) grants AI102106, AI080611, and AI103961, and Defense Advanced Research Projects Agency (DARPA) Contract HR0011-11-C0093. J.B.C. is supported by a fellowship from CAPES Foundation, Ministry of Education, Brazil. Work in the laboratory of I.G. was supported by Biotechnology and Biological Sciences Research Council grants BB/I012303/1 and BB/K002465/1, and Wellcome Trust grant WT097997MA. Work in the laboratory of S.H. is funded by a start-up package from the Department of Pathology at the University of Chicago.

\section{Literature Cited}

Arias, A., Bailey, D., Chaudhry, Y., and Goodfellow, I. 2012. Development of a reverse-genetics system for murine norovirus 3: Long-term persistence occurs in the caecum and colon. J. Gen. Virol. 93:1432-1441.

Blasi, E., Barluzzi, R., Bocchini, V., Mazzolla, R., and Bistoni, F. 1990. Immortalization of murine microglial cells by a v-raf/v-myc carrying retrovirus. J. Neuroimmunol. 27:229-237.

Bocchini, V., Mazzolla, R., Barluzzi, R., Blasi, E., Sick, P., and Kettenmann, H. 1992. An immortalized cell line expresses properties of activated microglial cells. J. Neurosci. Res. 31:616-621.
Britton, P., Green, P., Kottier, S., Mawditt, K.L., Penzes, Z., Cavanagh, D., and Skinner, M.A. 1996. Expression of bacteriophage T7 RNA polymerase in avian and mammalian cells by a recombinant fowlpox virus. J. Gen. Virol. 77:963-967.

Bustin, S.A., Benes, V., Garson, J.A., Hellemans, J., Huggett, J., Kubista, M., Mueller, R., Nolan, T., Pfaffl, M.W., Shipley, G.L., Vandesompele, J., and Wittwer, C.T. 2009. The MIQE guidelines: Minimum information for publication of quantitative real-time PCR experiments. Clin. Chem. 55:611-622.

Buttigieg, K., Laidlaw, S.M., Ross, C., Davies, M., Goodbourn, S., and Skinner, M.A. 2013. Genetic screen of a library of chimeric poxviruses identifies an ankyrin repeat protein involved in resistance to the avian type I interferon response. J. Virol. 87:5028-5040.

Chachu, K.A., Strong, D.W., LoBue, A.D., Wobus, C.E., Baric, R.S., and Virgin, H.W. IV. 2008. Antibody is critical for the clearance of murine norovirus infection. J. Virol. 82:6610-6617.

Chaudhry, Y., Skinner, M.A., and Goodfellow, I.G. 2007. Recovery of genetically defined murine norovirus in tissue culture by using a fowlpox virus expressing T7 RNA polymerase. J. Gen. Virol. 88:2091-2100.

Cox, C., Cao, S., and Lu, Y. 2009. Enhanced detection and study of murine norovirus-1 using a more efficient microglial cell line. Virol. J. 6:196.

Gallagher, S.R. 2011. Quantitation of DNA and RNA with absorption and fluorescence spectroscopy. Curr. Protoc. Mol. Biol. 93:A.3D.1A.3D.14.

Gallagher, S., Winston, S.E., Fuller, S.A. and Hurrell, J.G.R. 2008. Immunoblotting and immunodetection. Curr. Protoc. Mol. Biol. 83:10.8.110.8.28.

Geissler, K., Parrish, C.R., Schneider, K., and Truyen, U. 1999. Feline calicivirus capsid protein expression and self-assembly in cultured feline cells. Vet. Microbiol. 69:63-66.

Gonzalez-Hernandez, M.B., Bragazzi Cunha, J., and Wobus, C.E. 2012. Plaque assay for murine norovirus. J. Vis. Exp. 66:e4297.

Green, K.Y. 2007. Caliciviridae. In Fields Virology (D.M. Knipe and P.M. Howley, eds.) pp. 949980. Lippincott Williams \& Wilkins, Philadelphia.

Higuchi, R., Dollinger, G., Walsh, P.S., and Griffith, R. 1992. Simultaneous amplification and detection of specific DNA sequences. Biotechnology 10:413-417.

Hsu, C.C., Wobus, C.E., Steffen, E.K., Riley, L.K., and Livingston, R.S. 2005. Development of a microsphere-based serologic multiplexed fluorescent immunoassay and a reverse transcriptase PCR assay to detect murine norovirus 1 infection in mice. Clin. Diagn. Lab. Immunol. 12:1145-1151.

Hwang, S., Maloney, N.S., Bruinsma, M.W., Goel, G., Duan, E., Zhang, L., Shrestha, B.,
Animal RNA Viruses

15K.2.59 
Diamond, M.S., Dani, A., Sosnovtsev, S.V., Green, K.Y., Lopez-Otin, C., Xavier, R.J., Thackray, L.B., and Virgin, H.W. 2012. Nondegradative role of Atg5-Atg12/Atg16L1 autophagy protein complex in antiviral activity of interferon gamma. Cell Host Microbe 11:397409.

Karst, S.M., Wobus, C.E., Lay, M., Davidson, J., and Virgin, H.W. IV. 2003. STAT1-dependent innate immunity to a Norwalk-like virus. Science 299:1575-1578.

Kim, J.A., Cho, K., Shin, M.S., Lee, W.G., Jung, N., Chung, C., and Chang, J.K. 2008. A novel electroporation method using a capillary and wiretype electrode. Biosens. Bioelectron. 23:13531360.

Kitajima, M., Oka, T., Tohya, Y., Katayama, H., Takeda, N., and Katayama, K. 2009. Development of a broadly reactive nested reverse transcription-PCR assay to detect murine noroviruses, and investigation of the prevalence of murine noroviruses in laboratory mice in Japan. Microbiol. Immunol. 53:531-534.

Lindenbach, B.D. 2009. Measuring HCV infectivity produced in cell culture and in vivo. Methods Mol. Biol. 510:329-336.

Lutfalla, G. and Uze, G. 2006. Performing quantitative reverse-transcribed polymerase chain reaction experiments. Methods Enzymol. 410:386400.

Madore, H.P., Treanor, J.J., and Dolin, R. 1986. Characterization of the Snow Mountain agent of viral gastroenteritis. J. Virol. 58:487-492.

Mahler, M. and Kohl, W. 2009. A serological survey to evaluate contemporary prevalence of viral agents and Mycoplasma pulmonis in laboratory mice and rats in western Europe. Lab. Anim. 38:161-165.

Mikeska, T. and Dobrovic, A. 2009. Validation of a primer optimisation matrix to improve the performance of reverse transcription-quantitative real-time PCR assays. BMC Res. Notes 2:112.

Mumphrey, S.M., Changotra, H., Moore, T.N., Heimann-Nichols, E.R., Wobus, C.E., Reilly, M.J., Moghadamfalahi, M., Shukla, D., and Karst, S.M. 2007. Murine norovirus 1 infection is associated with histopathological changes in immunocompetent hosts, but clinical disease is prevented by STAT1-dependent interferon responses. J. Virol. 81:3251-3263.

Neumann, E., Schaefer-Ridder, M., Wang, Y., and Hofschneider, P.H. 1982. Gene transfer into mouse lyoma cells by electroporation in high electric fields. $E M B O$ J. 1:841-845.

Parwani, A.V., Saif, L.J., and Kang, S.Y. 1990. Biochemical characterization of porcine enteric calicivirus: Analysis of structural and nonstructural viral proteins. Arch. Virol. 112:41-53.

Phelan, M.C. 2006. Techniques for mammalian cell tissue culture. Curr. Protoc. Mol. Biol. 74:A.3F.1-A.3F.18.

Piche, C. and Schernthaner, J.P. 2003. Background priming during reverse transcription by
oligo(dT) carried over from mRNA isolation. Biotechniques 34:720-722, 724.

Reed, L.J. and Muench, H. 1938. A simple method of estimating fifty per cent endpoints. Am. J. Hygiene 27:493-497.

Ruiz, S., Beauvillain, C., Mevelec, M.N., Roingeard, P., Breton, P., Bout, D., and Dimier-Poisson, I. 2005. A novel CD4CD8alpha+CD205+CD11b- murine spleen dendritic cell line: Establishment, characterization and functional analysis in a model of vaccination to toxoplasmosis. Cell Microbiol. 7:16591671.

Smith, D.B., McFadden, N., Blundell, R.J., Meredith, A., and Simmonds, P. 2012. Diversity of murine norovirus in wild-rodent populations: Species-specific associations suggest an ancient divergence. J. Gen. Virol. 93:259-266.

Somogyi, P., Frazier, J., and Skinner, M.A. 1993. Fowlpox virus host range restriction: Gene expression, DNA replication, and morphogenesis in nonpermissive mammalian cells. Virology 197:439-444.

Stahlberg, A., Kubista, M., and Pfaffl, M. 2004. Comparison of reverse transcriptases in gene expression analysis. Clin. Chem. 50:1678-1680.

Stanley, E.R., Guilbert, L.J., Tushinski, R.J., and Bartelmez, S.H. 1983. CSF-1-a mononuclear phagocyte lineage-specific hemopoietic growth factor. J. Cell Biochem. 21:151-159.

Takeshita, S., Kaji, K., and Kudo, A. 2000. Identification and characterization of the new osteoclast progenitor with macrophage phenotypes being able to differentiate into mature osteoclasts. $J$. Bone Miner. Res. 15:1477-1488.

Taube, S., Perry, J.W., Yetming, K., Patel, S.P., Auble, H., Shu, L., Nawar, H.F., Lee, C.H., Connell, T.D., Shayman, J.A., and Wobus, C.E. 2009. Ganglioside-linked terminal sialic acid moieties on murine macrophages function as attachment receptors for murine noroviruses. $J$. Virol. 83:4092-4101.

Thackray, L.B., Wobus, C.E., Chachu, K.A., Liu, B., Alegre, E.R., Henderson, K.S., Kelley, S.T., and Virgin, H.W. IV 2007. Murine noroviruses comprising a single genogroup exhibit biological diversity despite limited sequence divergence. J. Virol. 81:10460-10473.

Timofeeva, A.V. and Skrypina, N.A. 2001. Background activity of reverse transcriptases. Biotechniques 30:22-24, 26, 28.

Tsunesumi, N., Sato, G., Iwasa, M., Kabeya, H., Maruyama, S., and Tohya, Y. 2012. Novel murine norovirus-like genes in wild rodents in Japan. J. Vet. Med. Sci. 74:1221-1224.

Tuiskunen, A., Leparc-Goffart, I., Boubis, L., Monteil, V., Klingstrom, J., Tolou, H.J., Lundkvist, A., and Plumet, S. 2010. Self-priming of reverse transcriptase impairs strand-specific detection of dengue virus RNA. J. Gen. Virol. 91:1019-1027.

Vashist, S., Urena, L., Chaudhry, Y., and Goodfellow, I. 2012a. Identification of RNA-protein interaction networks involved in the norovirus life cycle. J. Virol. 86:11977-11990. 
Vashist, S., Urena, L., and Goodfellow, I. 2012b. Development of a strand specific real-time RT-qPCR assay for the detection and quantitation of murine norovirus RNA. J. Virol. Methods 184:69-76.

Voytas, D. 2000. Agarose gel electrophoresis. Curr. Protoc. Mol. Biol. 51:10.4.1-10.4.8.

Ward, V.K., McCormick, C.J., Clarke, I.N., Salim, O., Wobus, C.E., Thackray, L.B., Virgin, H.W. IV, and Lambden, P.R. 2007. Recovery of infectious murine norovirus using pol II-driven expression of full-length cDNA. Proc. Natl. Acad. Sci. U.S.A. 104:11050-11055.

Wobus, C.E., Karst, S.M., Thackray, L.B., Chang, K.O., Sosnovtsev, S.V., Belliot, G., Krug, A., Mackenzie, J.M., Green, K.Y., and Virgin, H.W. 2004. Replication of Norovirus in cell culture reveals a tropism for dendritic cells and macrophages. PLoS Biol. 2:e432.

Wobus, C.E., Thackray, L.B., and Virgin, H.W. IV. 2006. Murine norovirus: A model system to study norovirus biology and pathogenesis. $\mathrm{J}$. $\mathrm{Vi}$ rol. 80:5104-5112.

$\mathrm{Xu}$, J. 2005. Preparation, culture, and immortalization of mouse embryonic fibroblasts. Curr. Protoc. Mol. Biol. 70:28.1.1-28.1.8.
Yunus, M.A., Chung, L.M., Chaudhry, Y., Bailey, D., and Goodfellow, I. 2010. Development of an optimized RNA-based murine norovirus reverse genetics system. J. Virol. Methods 169:112-118.

Zumstein, L. 1998. Dialysis and ultrafiltration. Curr. Protoc. Mol. Biol. 41:A.3C.1-A.3C.7.

\section{Internet Resources}

http://www.bio-protocol.org/wenzhang.aspx?id= 415

A protocol for the generation of a neutral redcontaining $M N V$ stock to measure replicating virus can be found at this site.

http://www.jove.com/video/4145/reversegenetics-mediated-recovery-

of-infectious-murine-norovirus

$A$ video for the generation of recombinant $M N V$ can be found at this site.

http://www.lindenbachlab.org/resources.html Excel spreadsheet for calculating $T C I D_{50}$ values.

http://www.jove.com/video/4297/plaqueassay-for-murine-norovirus

A video for the plaque assay can be found at this site.

http://www.endmemo.com/bio/dnacopynum.php A link to convert RNA concentration to copy number.
Animal RNA Viruses 